\title{
First large-scale ethnobotanical survey in the province of Uíge, northern Angola
}

\author{
Thea Lautenschläger ${ }^{1 *} \mathbb{D}$, Mawunu Monizi ${ }^{2}$, Macuntima Pedro², José Lau Mandombe², Makaya Futuro Bránquima²,
} Christin Heinze ${ }^{1}$ and Christoph Neinhuis ${ }^{1}$

\begin{abstract}
Background: Angola suffered a long-lasting military conflict. Therefore, traditional knowledge of plant usage is still an important part of cultural heritage, especially concerning the still very poor health care system in the country. Our study documents for the first time traditional knowledge of plant use of local Bakongo communities in the northern province of Uíge on a large scale with a focus on medicinal plants and puts data in context to different parameters of age, gender and distance to the provincial capital.

Methods: Field work was carried out during nine field trips in 13 municipalities between October 2013 and October 2016. In 62 groups, 162 informants were interviewed. Herbarium specimens were taken for later identification. Database was analysed using Relative Frequency of Citations, Cultural Importance Index, and Informant Consensus Factor. Furthermore, significances of influence of age, gender and distance were calculated.

Results: Our study presents 2390 use-reports, listing 358 species in 96 plant families, while just three out of 358 mentioned species are endemic to Angola about one-fifth are neophytes. The larger the distance, the higher the number of use citations of medical plants. Although women represent just a fifth of all citations (22\%), their contribution to medicinal plants was proportionally even higher (83\%) than those of men (74\%). Fifty percent of all plants mentioned in the study were just listed by men, $12 \%$ just by women. We made some new discoveries, for example. Gardenia ternifolia seems to be promising for treatment of measles, and Annona stenophylla subsp. cuneata has never been ethnobotanically nor phytochemically investigated.
\end{abstract}

Conclusions: While the study area is large, no significant influence of the distance in regard to species composition in traditional healer's concepts of the respective village was pointed out. Although several plants were just mentioned by women or men, respectively, no significant restriction to gender-specific illnesses in medical plant use could be found. Merely concerning the age of informants, a slight shift could be detected.

Keywords: Medicinal plants, Angola, Ethnobotany, Influence of distance, Gender-specific, Neophytes

\section{Background}

Angola is regarded as a country with an unusually rich biodiversity covering a high amount of vegetation zones and habitats [1, 2]. Although several botanists, among them Friedrich Welwitsch (1806-1872), Hugo Baum (1867-1950) and John Gossweiler (1873-1952), visited and studied this richness, the war lasting 40 years did not allow them to carry out continuous botanical or ethnobotanical investigations [1]. Bossard (1987, 1993)

\footnotetext{
* Correspondence: thea.lautenschlaeger@tu-dresden.de

'Department of Biology, Institute of Botany, Faculty of Science, Technische Universität Dresden, 01062 Dresden, Germany

Full list of author information is available at the end of the article
}

investigated Ovimbundu traditional medicine, listing plant names just in Ovimbundu language without identifying botanical species $[3,4]$. Nowadays, the considerable work of Figueiredo and Smith [1] creating a plant checklist for the country with about 7000 species represents a useful database for following and future studies. While quite a number of surveys were conducted in Southern Angola, just a few are located in the northern part $[5,6]$. Göhre et al. [7] collected ethnobotanical data in disturbed areas around the city of Uíge. Monizi et al. [8] described a high variety of wild plants used for securing human survival in Ambuila, one of the 16 municipalities in the province of Uíge [8]. Heinze et al. [9] conducted the first ethnobotanical

(C) The Author(s). 2018 Open Access This article is distributed under the terms of the Creative Commons Attribution 4.0 International License (http://creativecommons.org/licenses/by/4.0/), which permits unrestricted use, distribution, and 
studies in the neighbouring province Cuanza Norte. Specific descriptions of fibre uses were given by Senwitz et al. [10]. According to the distribution of the ethnic tribe Bakongo, covering northern Angola as well as the adjacent Bas-Congo area, ethnobotanical studies conducted in the Democratic Republic of Congo should reveal comparable results of ethnobotanical uses in Angola [11].

Traditional knowledge is essential for the healthy cultural and social life within a society [12]. It is generally assumed that indigenous traditional knowledge information is going to be lost because it is, at least partly no longer essential for the survival of people. This is either due to influences such as the rapid development of rural areas or because of displacement of indigenous people $[13,14]$. Although several infrastructure measures were undertaken in Angola, development is still slow, especially regarding the public health sector. Even if child mortality in Africa decreased during the last two decades, it is still very high. More specifically, Angola has the highest rate in Africa and worldwide and, following Sierra Leone the lowest life expectancy for women and men worldwide $[15,16]$. Sousa-Figueiredo et al. [17] detected malnutrition and anaemia as public health problems. Smith et al. [18] documented that the overall prevalence of malnutrition is higher in rural than then in urban areas. In this context, ethnobotanical studies in northern Angola seemed reasonable not only in terms of documentation of the current state but urgently needed to record still existing knowledge. Furthermore, Moyo et al. [19] stated that the rich flora of sub-Saharan Africa suggests enormous potential for discovery of new chemical components with therapeutic value.

In our large-scaled survey in the northern province of Uíge, covering about $60,000 \mathrm{~km}^{2}, 13$ out of 16 municipalities were visited, including both savannah and forest formations. Therefore, this study for the first time

1. Provides an overview of traditional plant uses and health methods in the province of Uíge

2. Highlights native as well as introduced plant species used in traditional medicine

3. Analyses the influence of gender, age and distance from the province capital Uíge with regard to uses and methods

\section{Methods}

\section{Study area}

The studies were conducted in the province of Uíge located in the very north of Angola, bordering in the north and east to the Democratic Republic of the Congo, in the south to the provinces of Malanje, Cuanza Norte, and Bengo, and in the west to Zaire province (Fig. 1). According to the Köppen climate classification, the province has a tropical wet or dry or savannah climate Aw [20, 21]. This so-called Guineo-Congolian rainforest climate is characterized by a rainy season lasting at least 6 months, relative air humidity above $80 \%$ and typical dense fog, locally called Cacimbo [22-24]. Due to the global ecoregions map defined by the World Wildlife Fund (WWF), the province of Uíge covers the ecoregion called the Western Congolian Forest-Savannah Mosaic [25]. A more precise description of the region was given by White [24] who classified Angola north between the Guineo-Congolian and the Zambesian Regions, i.e., the Guinea-Congolian/Zambesian Regional Transition Zone. According to that classification, this zone is characterized by a high complexity since elements of both formations are present. Edaphic conditions and the existence of a diverse topography strongly influence the formation of distinctive patterns of mosaic vegetation shown in Fig. 1c. Barbosa [26] subdivided the area into six vegetation zones, shown in Fig. 1d.

The long lasting war in Angola had a highly negative impact on biodiversity [27]. But also prior to the conflicts, several species of economic value on international timber markets like Milicia excelsa (Welw.) C.C.Berg or species of Entandrophragma were historically exploited and are still under increasing pressure [22]. This rising forest loss is confirmed by global analysis of satellite data [28]. Moyo et al. [19] calculate for Guinean Forests in West Africa a remaining area of $15 \%$. On the other hand, the National Report on forest resources by the FAO [29], based on data captured by Horsten, reported not more than $4 \%$ of the Uíge area as productive $[7,30]$. Beside deforestation, Göhre et al. [7] reported uncontrolled burning caused by growing agricultural activities. Hence, large areas are heavily disturbed anthropogenically resulting in an increased abundance of Zambezian floristic elements following the destruction of the original vegetation leaving only secondary grass- and woodland [24]. Recordings in the remaining forest patches exhibit tropical rainforest and savannah species assemblages comparable with the Bas-Congo region [11, 31, 32].

Since the vegetation formations are very heterogeneous, traditional use of plants by people is prevalent and manifold. The province comprises 16 municipalities, covering an area of $58.698 \mathrm{~km}^{2}$ inhabited by more than 1.4 million people [33], the majority of which belongs to the Kikongo speaking Bakongo ethnic group [33]. As this Bantu group is also living in the neighbouring countries Democratic Republic of the Congo, Republic of the Congo, and Gabon, manifold influences caused by migration due to political problems and conflicts are part of its culture. Very little is known about the health care system in Angola. Faith-based organizations' contribution to Angola's health care system is very low, compared to other sub-Saharan countries [34]. In turn, the government is cutting the health budget due to the 


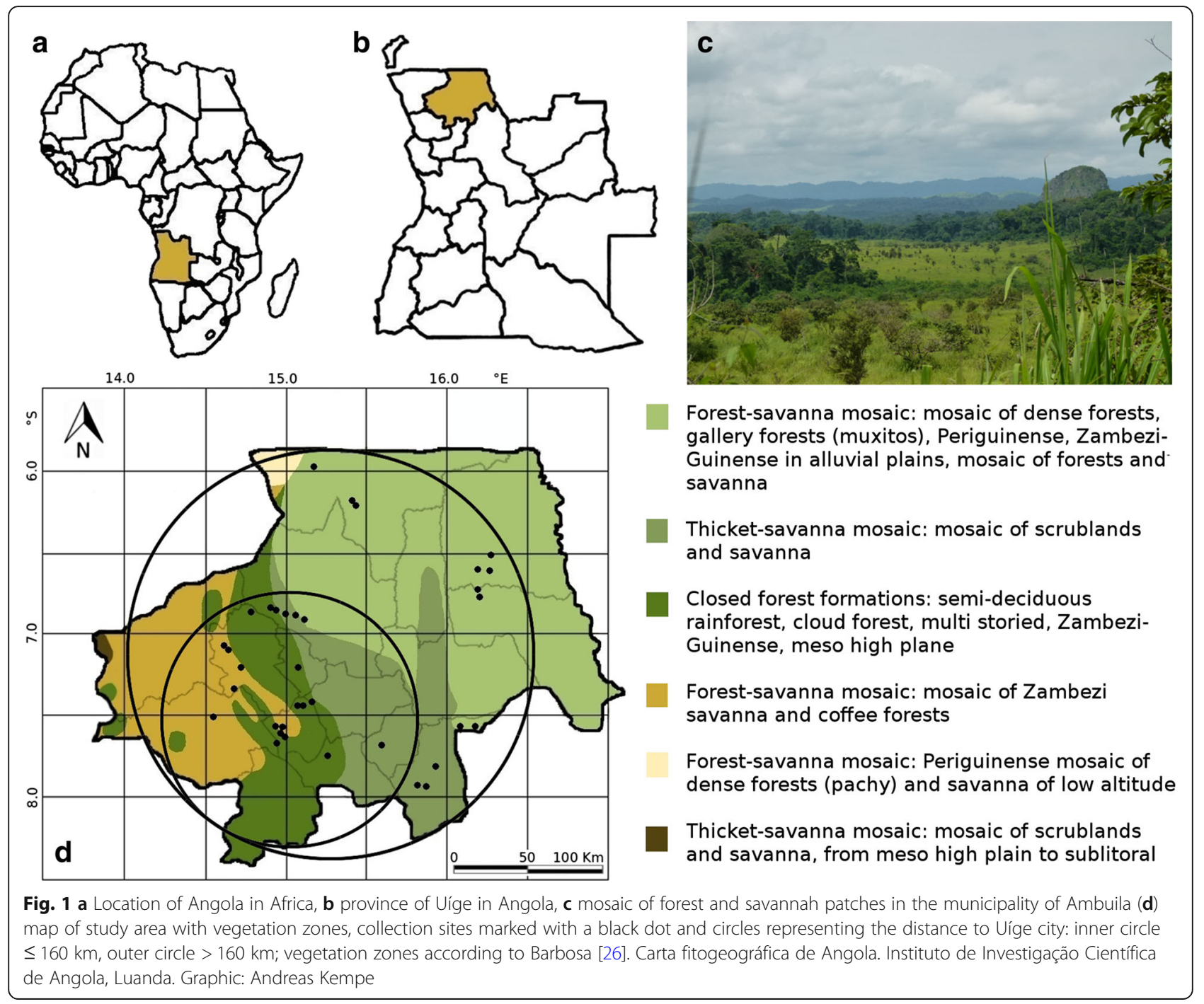

falling prices for oil [35]. The lack of health infrastructure, especially in rural areas, is a serious problem resulting in the constant importance of traditional healers and herbal medicines [36].

\section{Data collection}

Data sampling was carried out between $5^{\circ} 58^{\prime} 59.2^{\prime \prime}$ and $7^{\circ} 56^{\prime} 59.4^{\prime \prime}$ southern latitude and between $14^{\circ} 33^{\prime}$ 53.7" and $16^{\circ} 17^{\prime} 04.5^{\prime \prime}$ longitude, covering 35 localities in 13 municipalities (Fig. 1). According to the distance from the provincial capital Uíge, two distance levels $\mathrm{A}(\leq 160 \mathrm{~km})$ and B (170-330 km) were defined. During nine field trips between October 2013 and October 2016, 162 informants were involved in the study, 30 of those were interviewed on their own, 132 were interviewed in groups of two to five persons, bringing the total number of interviews to 62. In advance, the University Kimpa Vita formulated credentials to inform the mayors of the municipalities about the planned activities. To establish contact with potential informants, local authorities of the visited villages (called soba and seculo) were informed about the aims and methods of the study and asked to suggest persons with experience in traditional medicine that might participate (prior informed consent). Hence, all the interviews were conducted with at least one traditional herbalist sometimes accompanied by laypeople. We tried to form a gender-balanced research without violating cultural and/ or sacred taboos [37]. The specification of the obtained knowledge varied from location to location and person to person. Information was collected during semi-structured interviews, transect walks and group discussions [38]. Criteria used to define the uses reported are based on informant's statements. Since Silva et al. [39] recommended vegetation inventories to guarantee a correct identification of species and better identification by informants, walks into the traditionally used plant collecting areas were always part of interviews, including forest and savannah formations, since these two habitats alternate very frequently. 
During field-work, Portuguese language was mainly used, however, in some cases, Angolan colleagues translated into Kikongo. Gender and age of every informant was documented wherever possible. In those cases where the informant did not know his exact age, it was estimated whether the person was younger or older than 40 . The following data sets were requested: local plant name, its usage, used plant part and preparation techniques. In case of medicinal plants administration techniques were also documented. Local market surveys and field trips for collecting herbarium specimens completed the investigations. All processes of the surveys were permitted and accompanied by the local authorities. Following the advice made by Ramirez [14] to allow a better contribution and exchange of knowledge, we invited several informants to our presentations and discussions at the University Kimpa Vita in Uíge city. The code of ethics of the International Society of Ethnobiology was followed. The study was carried out in compliance with the agreement of Access and Benefit Sharing. For identification, plants were photographed and plant voucher specimens were collected, dried and stored at the Dresden herbarium (Herbarium Dresdense), Technische Universität Dresden, Germany. In a Memorandum of Understanding between the Instituto Nacional da Biodiversidade e Áreas de Conservação (INBAC), Angola and the Technische Universität Dresden, Germany, signed in 2014, it was agreed upon that duplicates will be returned to Angola as soon as appropriate conditions to store the herbarium vouchers are established. The Ministry of Environment Angola and the Province Government of Uíge issued the required collection and export permits. Identification of collected plant specimens and data analysis was completed in Dresden, Germany. For identification, several floristic works were used: Conspectus Florae Angolensis [40], Plantas de Angola [1], Flore Analytique du Bénin [41], Flora of Tropical West Africa [42-46], and Flora Zambesiaca [47]. Additional information was retrieved from Kew Herbarium Catalogue [48] and Naturalis Biodiversity Center [49]. Furthermore, for some plant families, specialists were consulted. The Herbario LISC and Herbario COI were visited in July 2016 and 2017 for comparing plant samples [50]. Use-reports of identified plants were only included in the results if the specimen was at least determined to genus level. The nomenclature used refers to Plantlist.org. Voucher specimen numbers of Herbarium Dresdense as well as photo voucher numbers are given in Table 1. Due to the poor availability of data regarding the information of endangered species, Table 1 includes only additional details on endemism and states of neophytes.

\section{Data analysis and ethnobotanical indices}

All collected data sets were put into a database using Microsoft Excel. Corresponding to the research issue, the use of pivot-tables allowed the systematic processing of the large and detailed data set (nearly 40,000 data fields) to correlate different features with each other. Tableau Software was used to create selected diagrams. The basic structure of use-reports to list the information follows the principle "informant i mentions the use of species $\mathrm{s}$ in the use category $\mathrm{u}$ " $[51,52]$. Out of the collected data, 10 use categories were defined: "medicinal use (M)"; "nutrition, spices and herbal teas (N)"; "domestic and charcoal (D)"; "Hunting, fishing and animal feed (F)"; "dental care and cosmetics (T)"; "drugs and cigarettes (C)"; "handicrafts (H)"; "ludic, childrens' toys (L)"; and "rituals (R)". Uses mentioned less than eight times were summarized in "Others $(\mathrm{O})$ ", including soaps, toilet paper, glue or agricultural purpose like soil improvement inter alia. Since the majority of data refers to medicinal plants, this category was differentiated into 41 secondary categories according to the treated illnesses (Table 5). We used this detailed classification to enable later pharmaceutical studies because in this field the local people who provide information are not capable of classifying different subcategories according to modern medicine since ethnobotanical indigenous knowledge in several cases does not clearly distinguish.

Statistical methods were performed to figure out the influence of age, gender, plant habitat, and distance to Uíge city, use categories and application forms to each other. Chi-square test of independence was used to determine whether a significant relation between two variables exists [53]. Using the Checklist of Plants in Angola [1], the proportion of neophytes was determined.

In order to allow comparing recorded data to other studies, the following quantitative ethnobotanical indices were calculated: Relative Frequency of Citations (RFC), Cultural Importance Index (CI) as well as the Informant Consensus Factor $\left(\mathrm{F}_{\mathrm{IC}}\right)$ regarding the secondary categories of illnesses. The Relative Frequency of Citations presents the local significance of each plant species and is calculated for each species as the quotient of the frequency of citations (FC) and the total number of informants (N) [54] (Formula 1). Tardío and Pardo-de-Santayana [51] introduced the CI to ensure data of different studies being compared due to versatility of species use. If the species use would be mentioned in every use category, ten in our study, the CI would be this total number of use categories, i.e. also 10 [51]. In case the species is used in just one use category the CI would be equal to the RFC (Formula 2). Since interviews often were conducted in groups of informants, the number of groups (62) instead of the number of informants (162) was used to calculate the indices.

$\mathrm{F}_{\mathrm{IC}}$ indicates the homogeneity of the knowledge of the informants [55] (Formula 3). Values differ from 0 (no concordance) to 1 (full accordance). High values therefore 


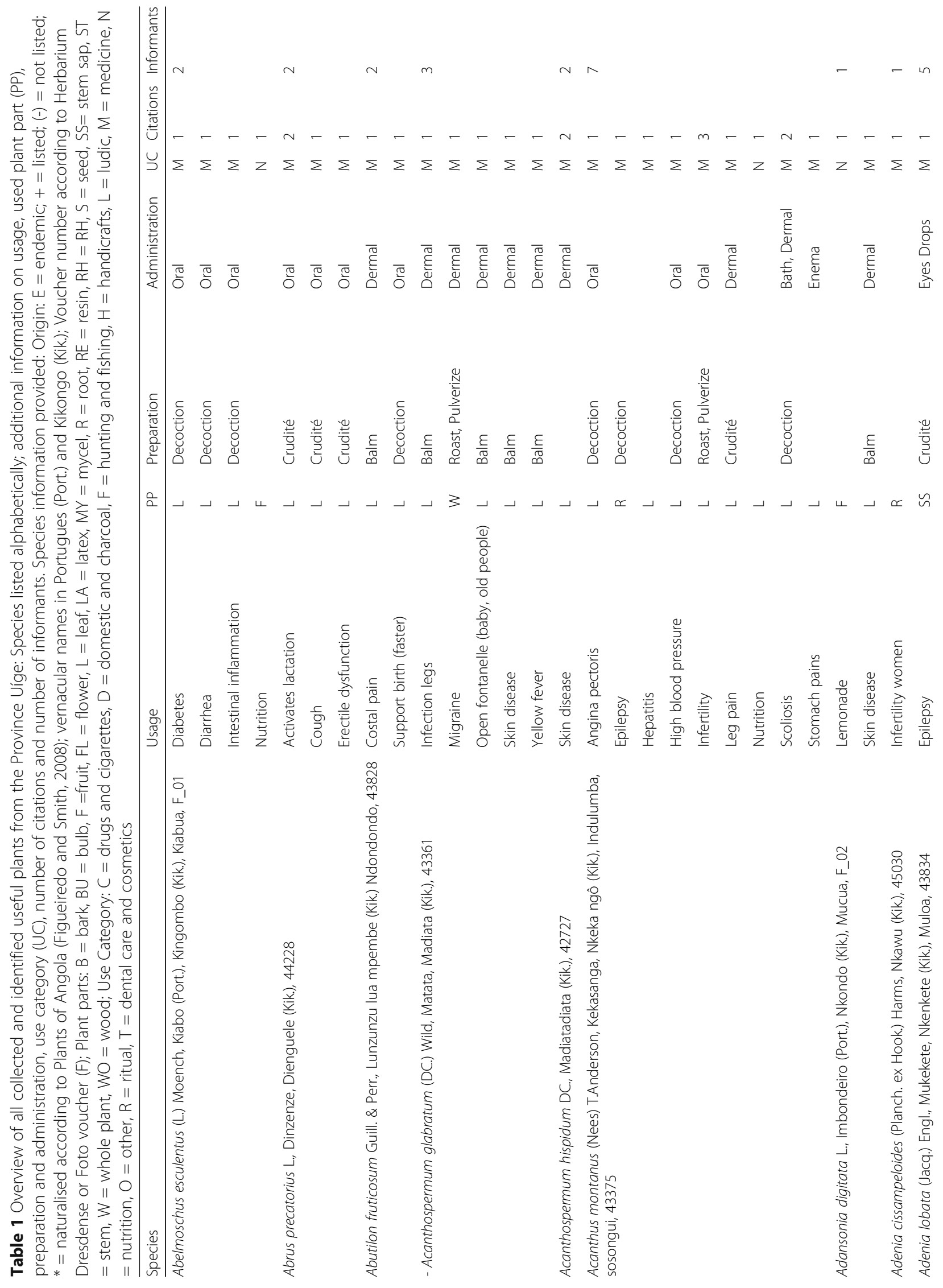




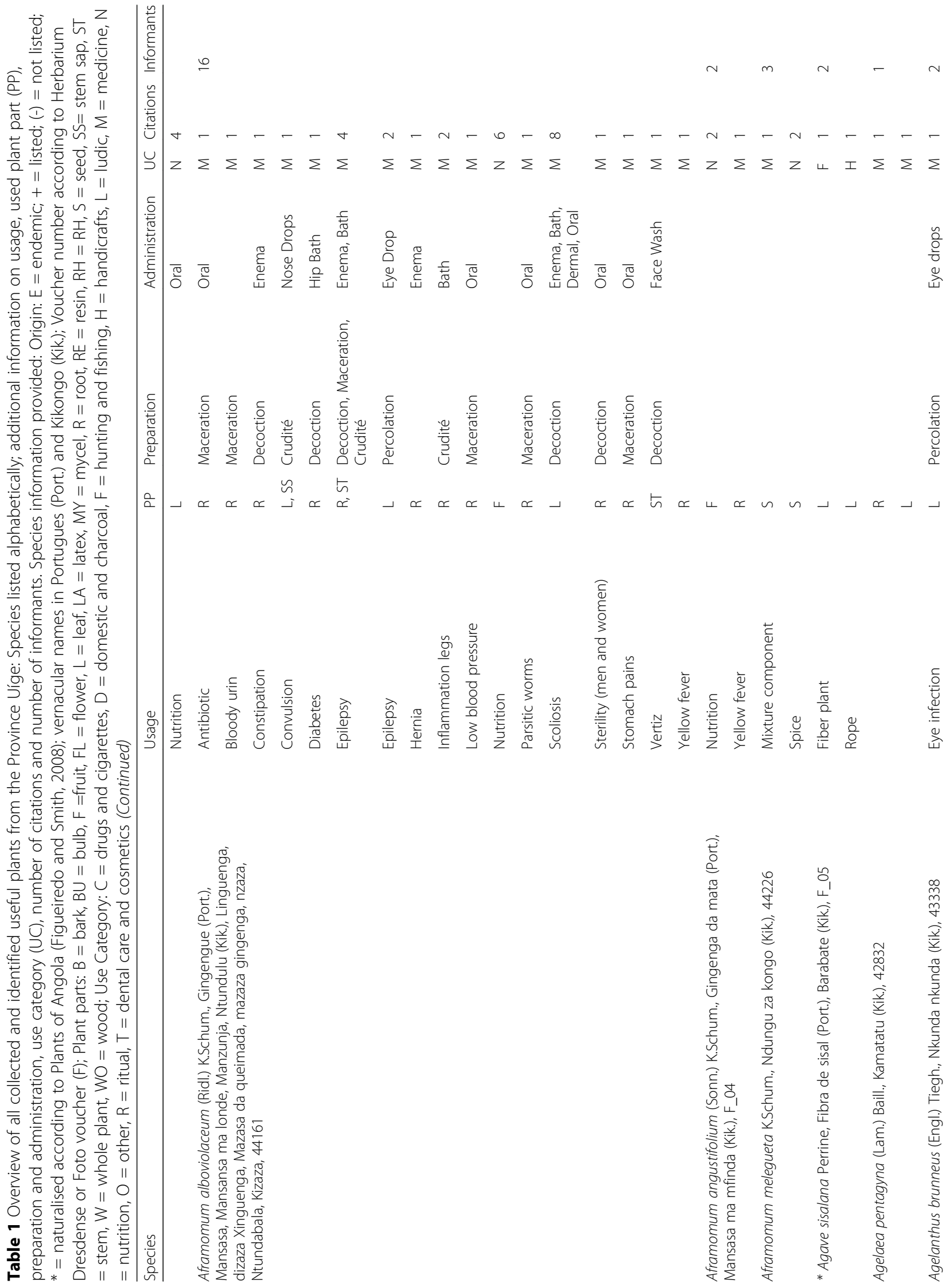




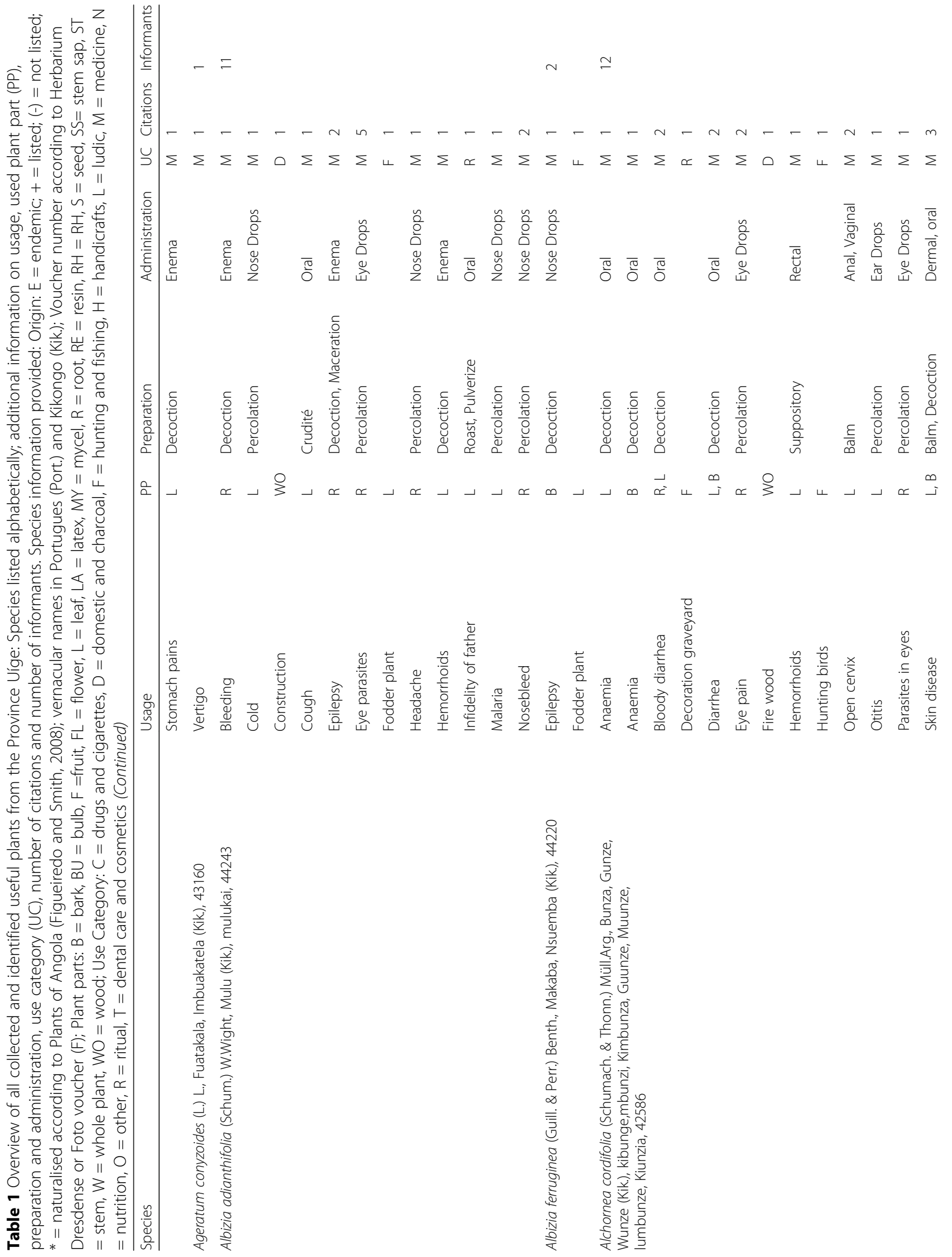




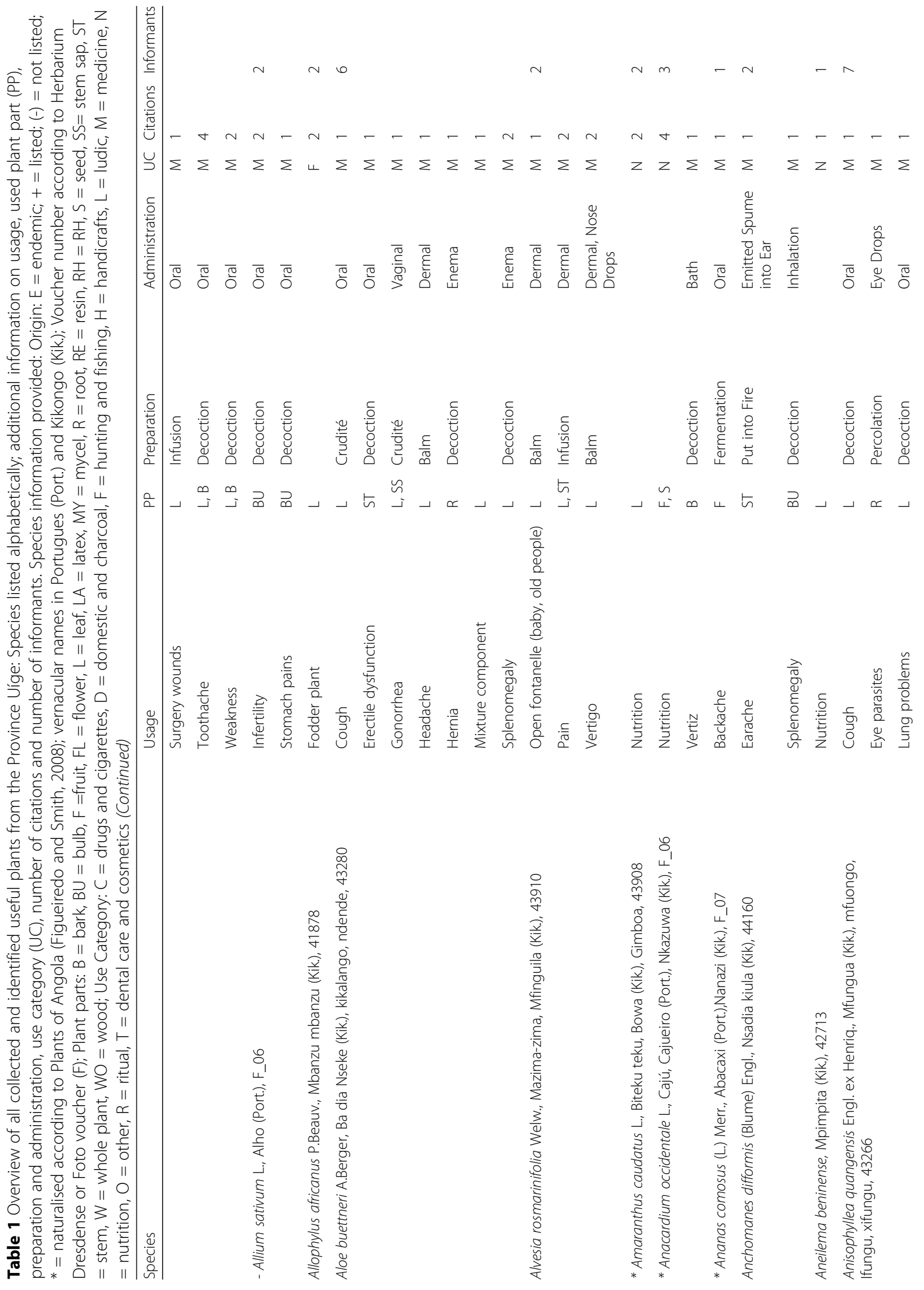




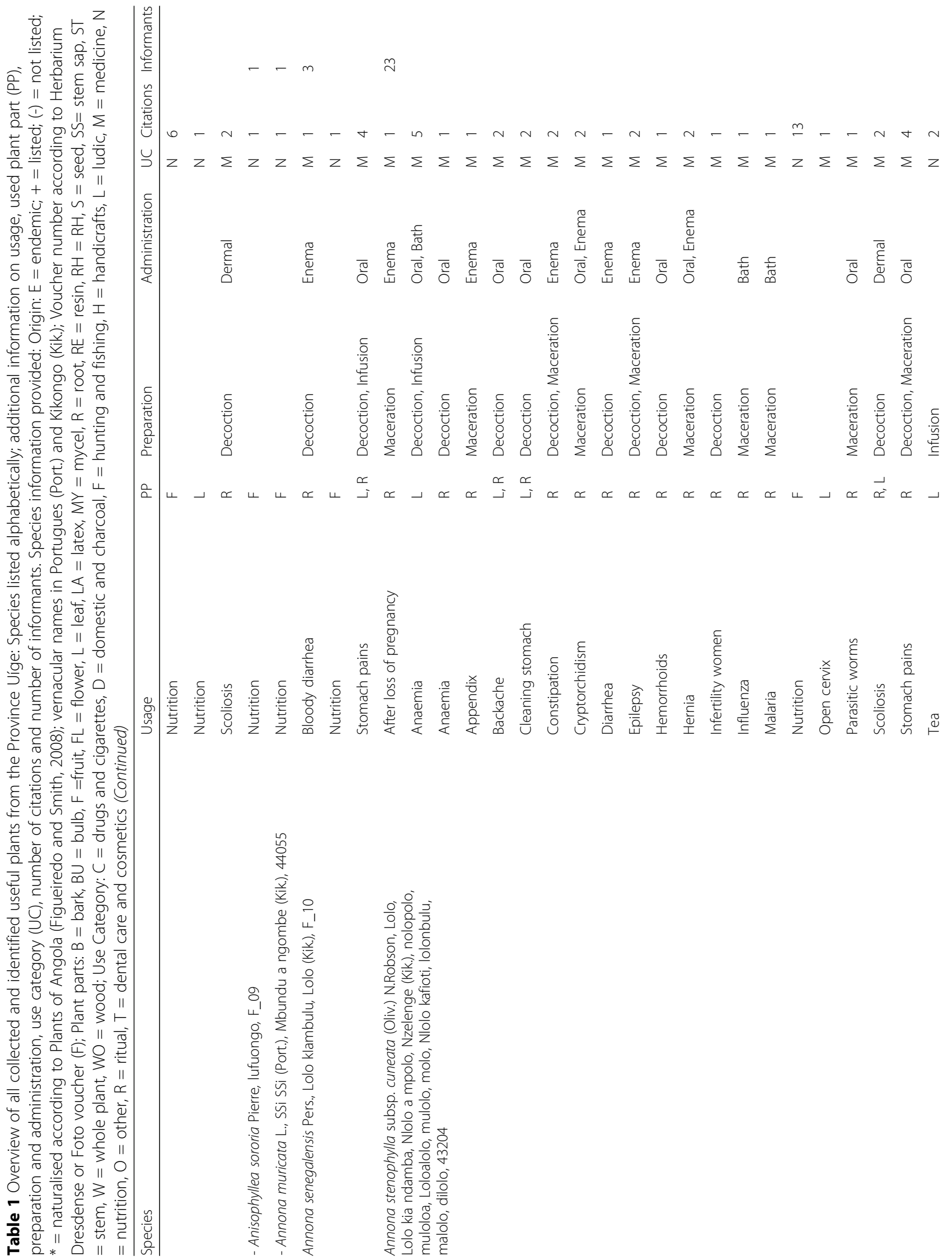




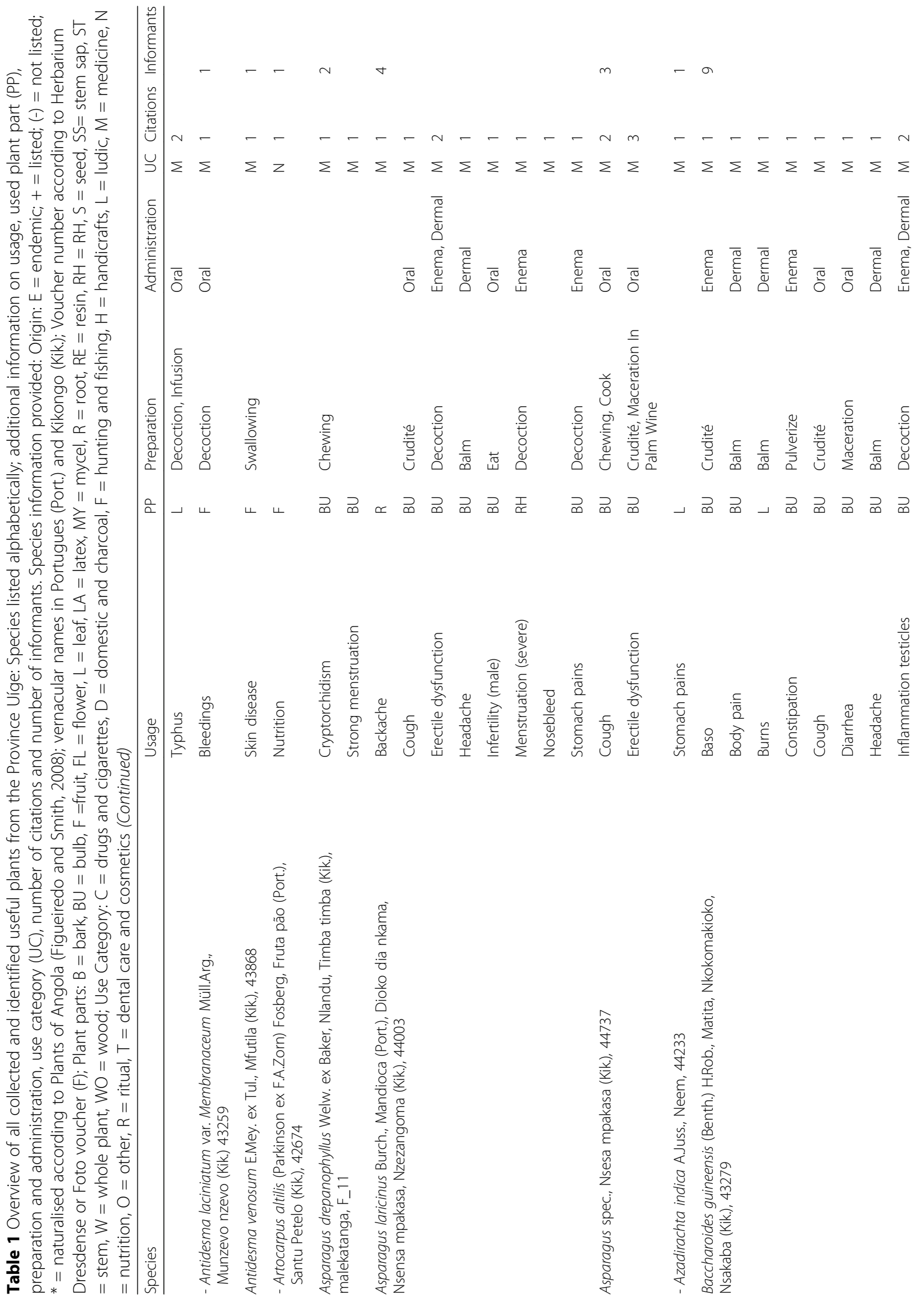




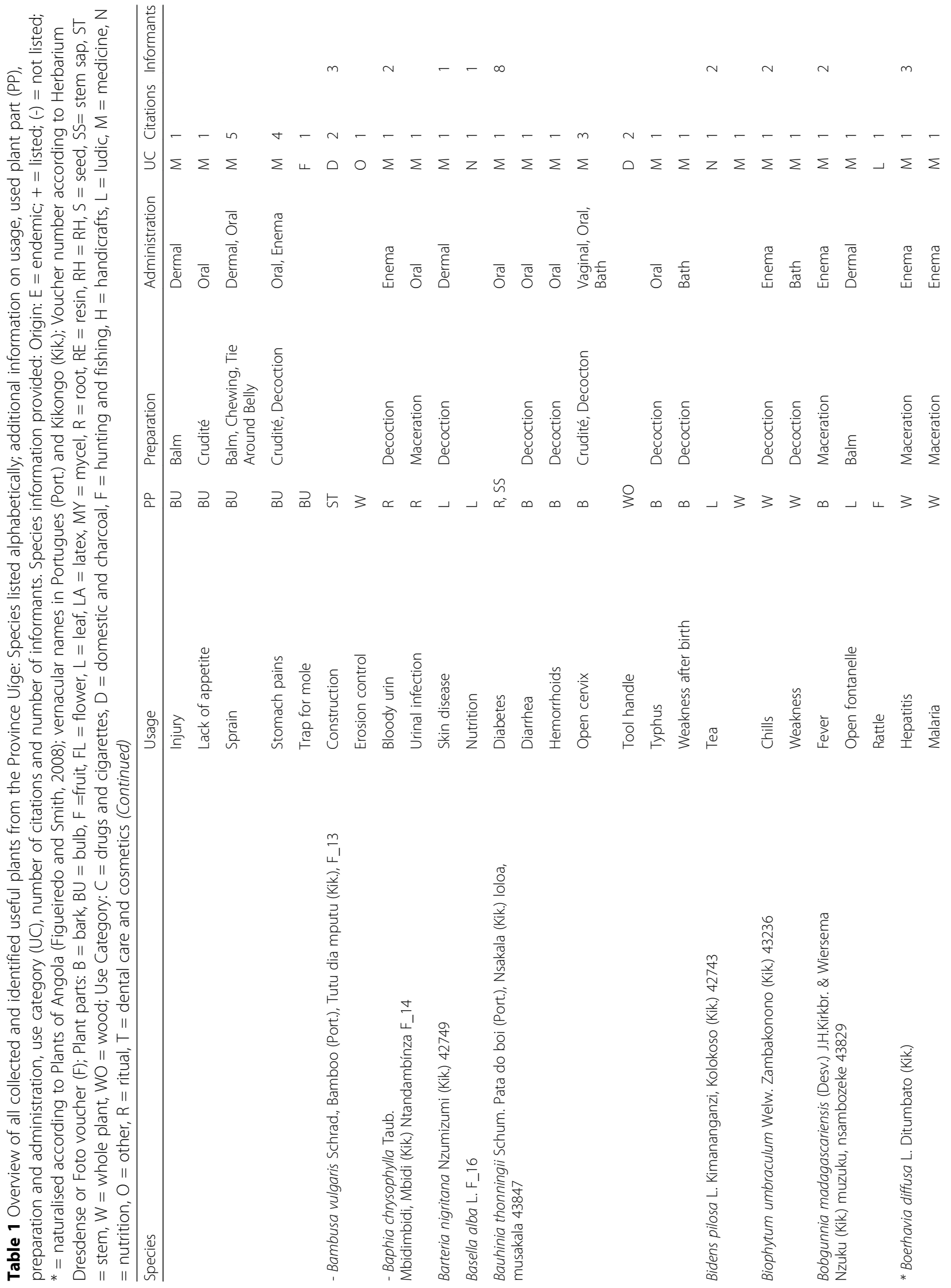




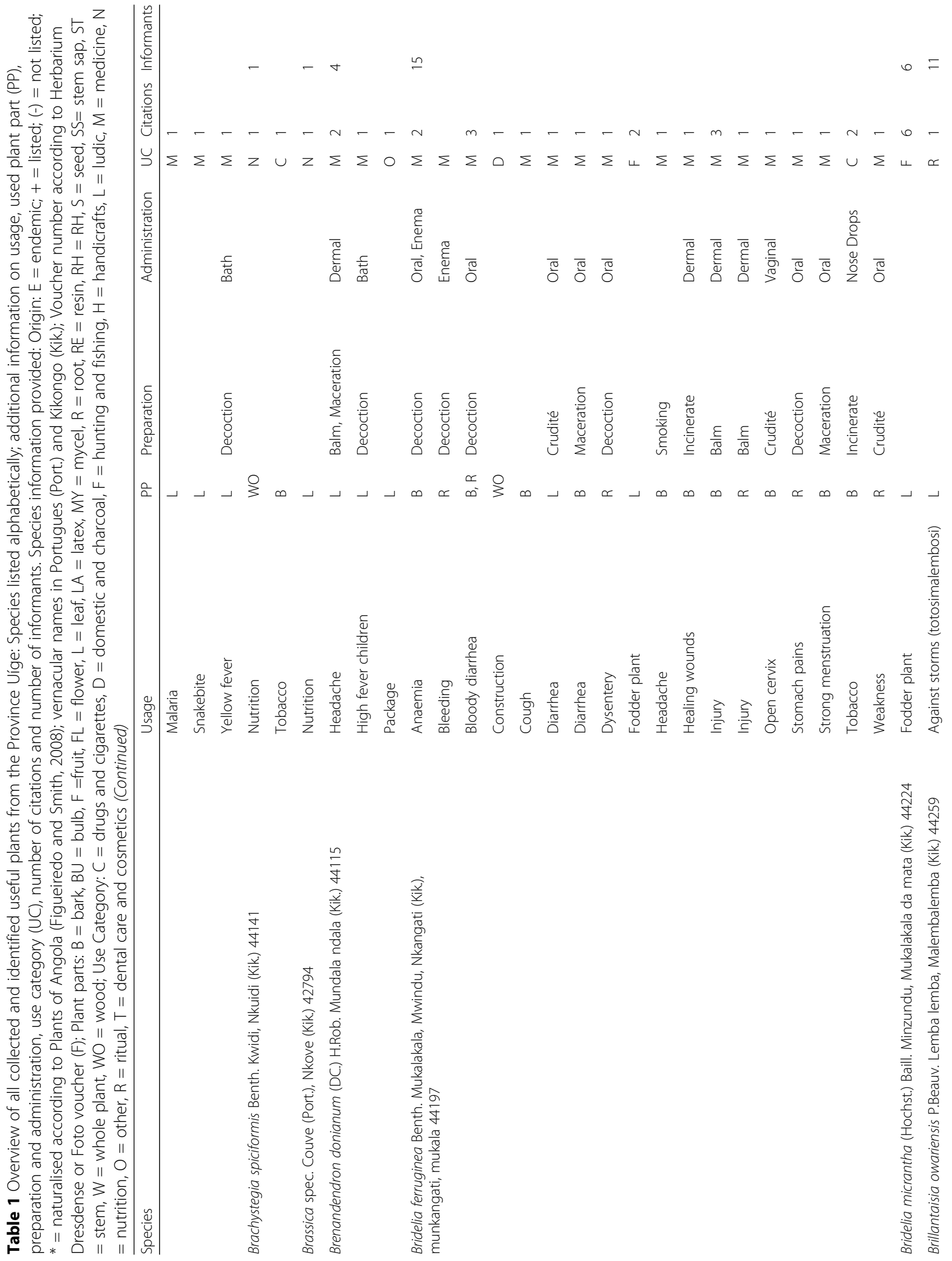




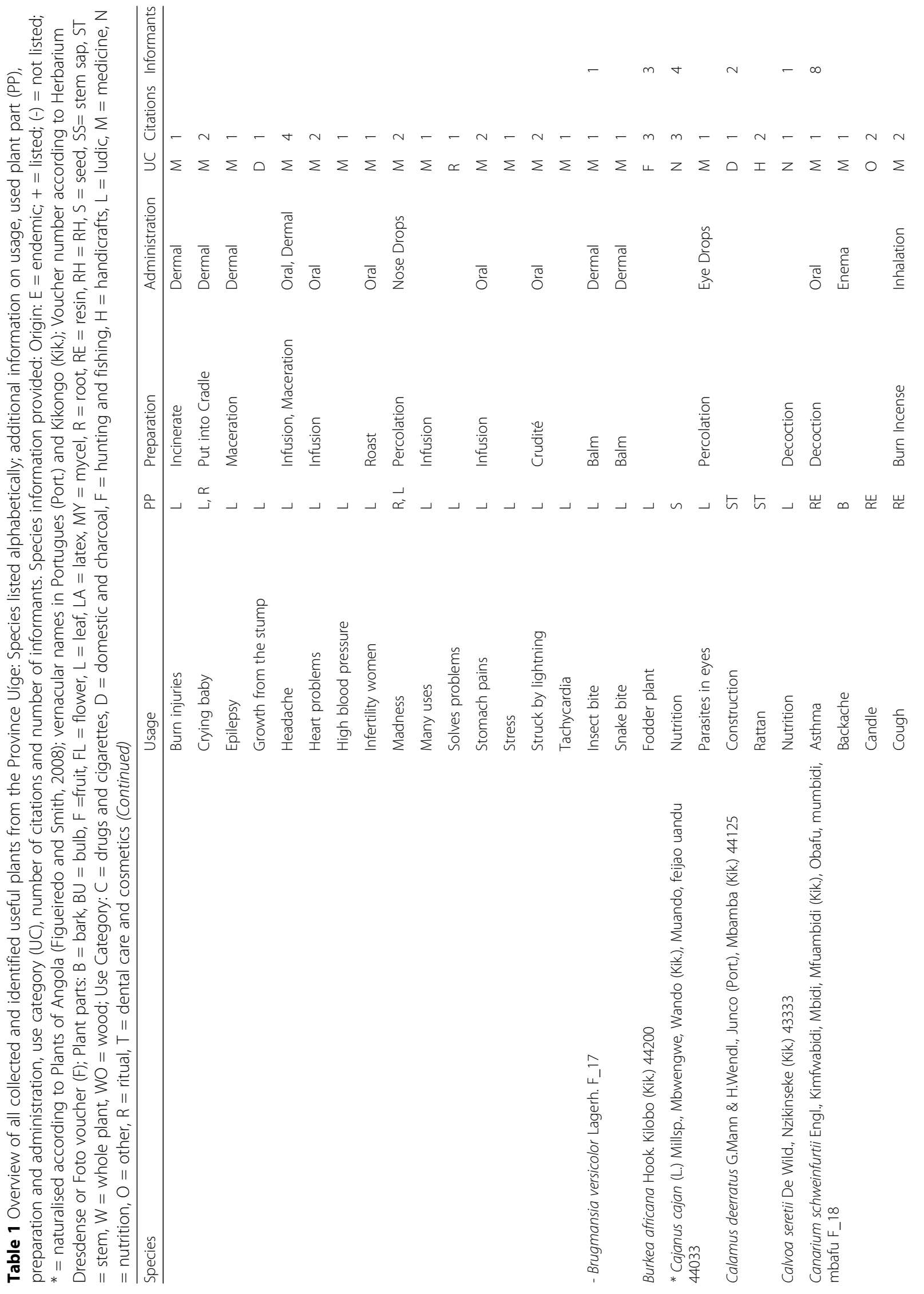




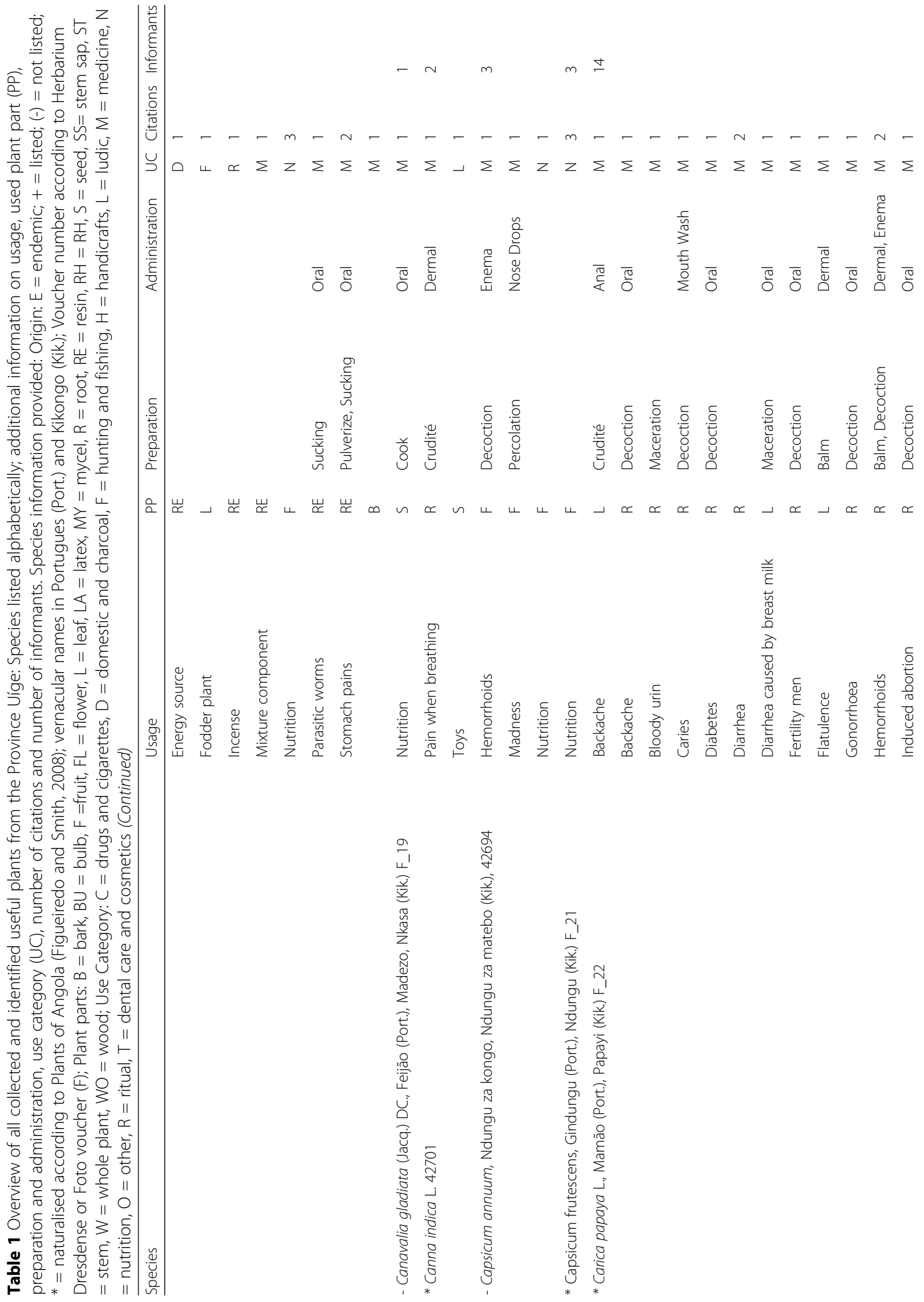




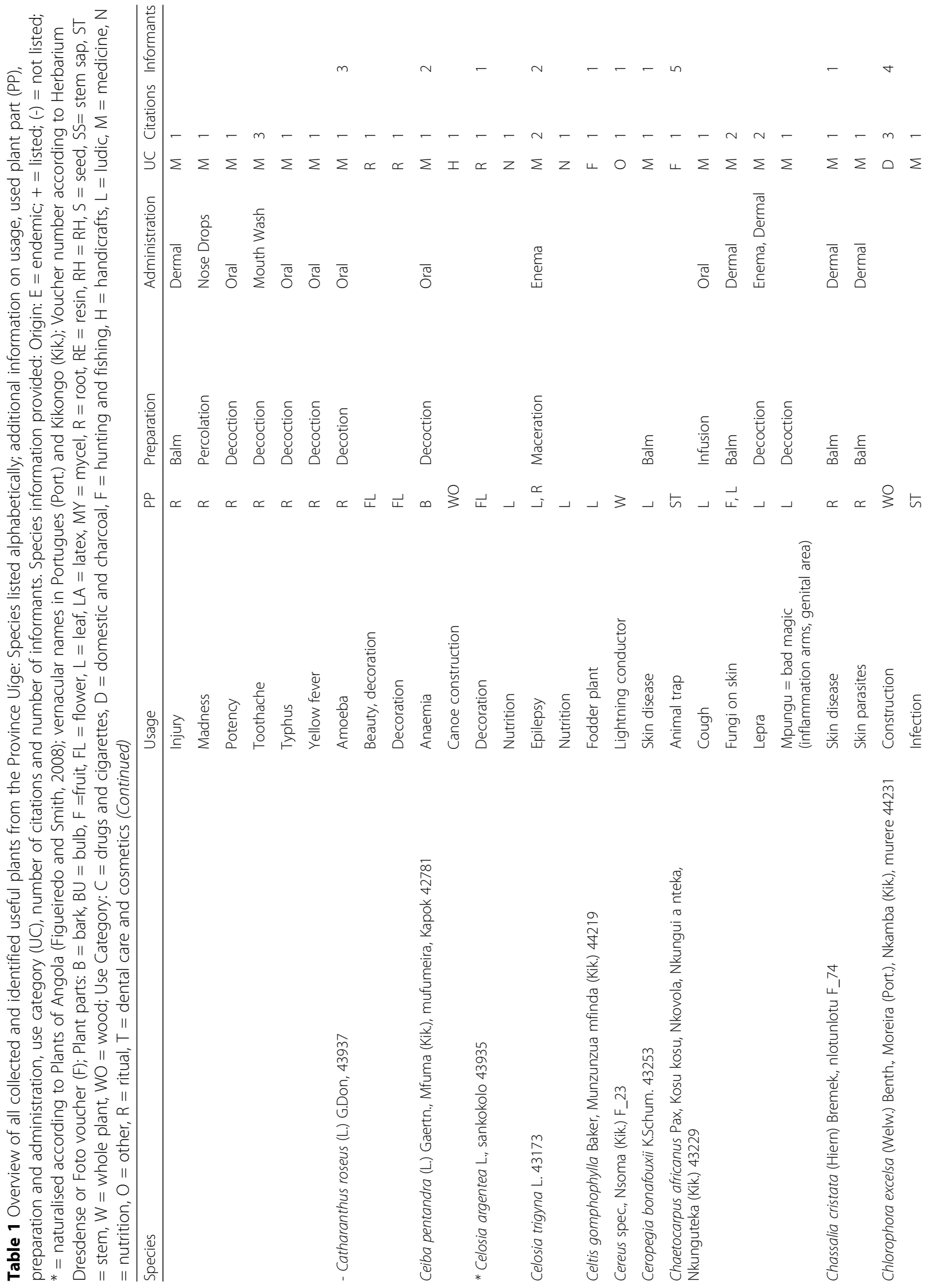




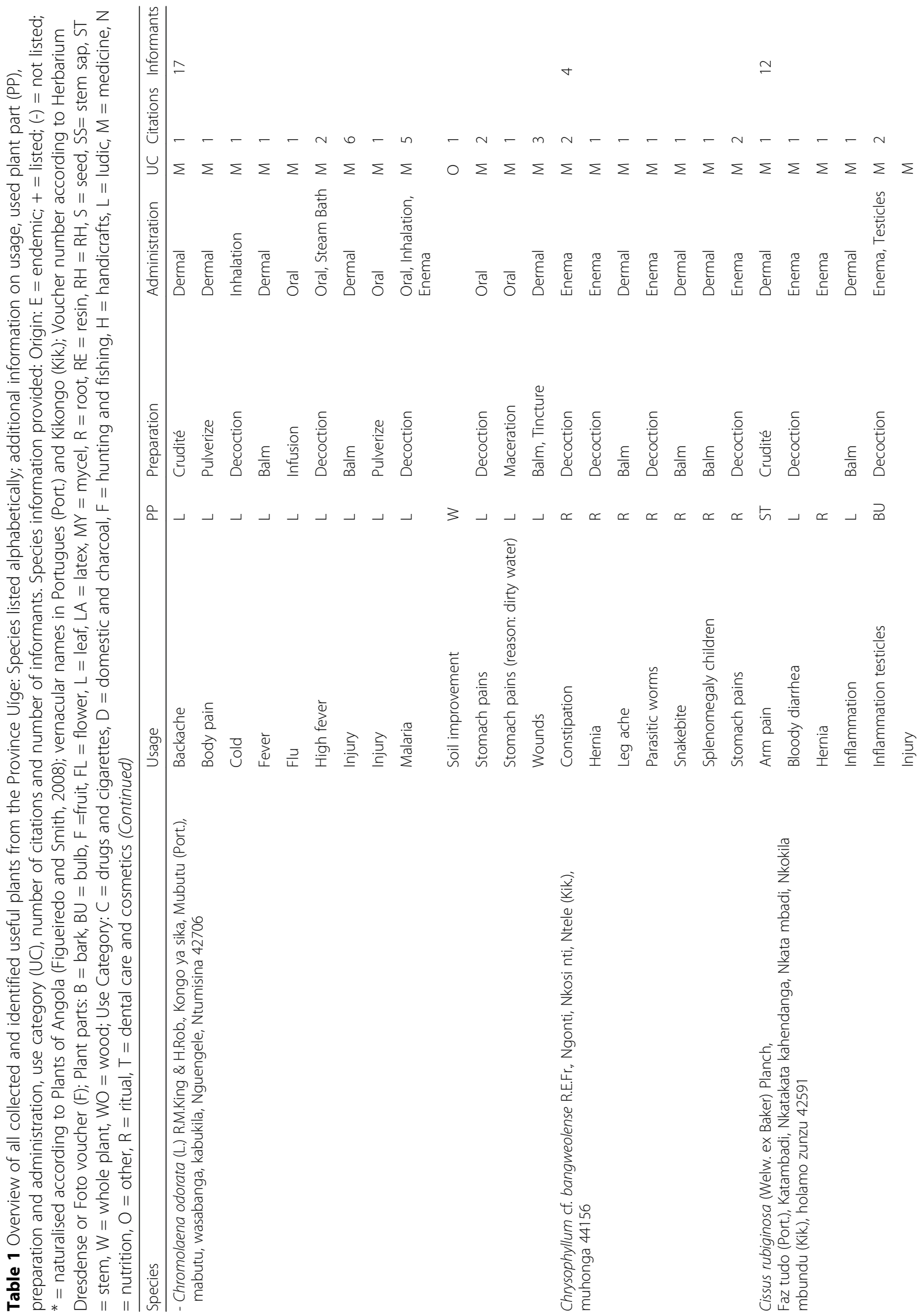




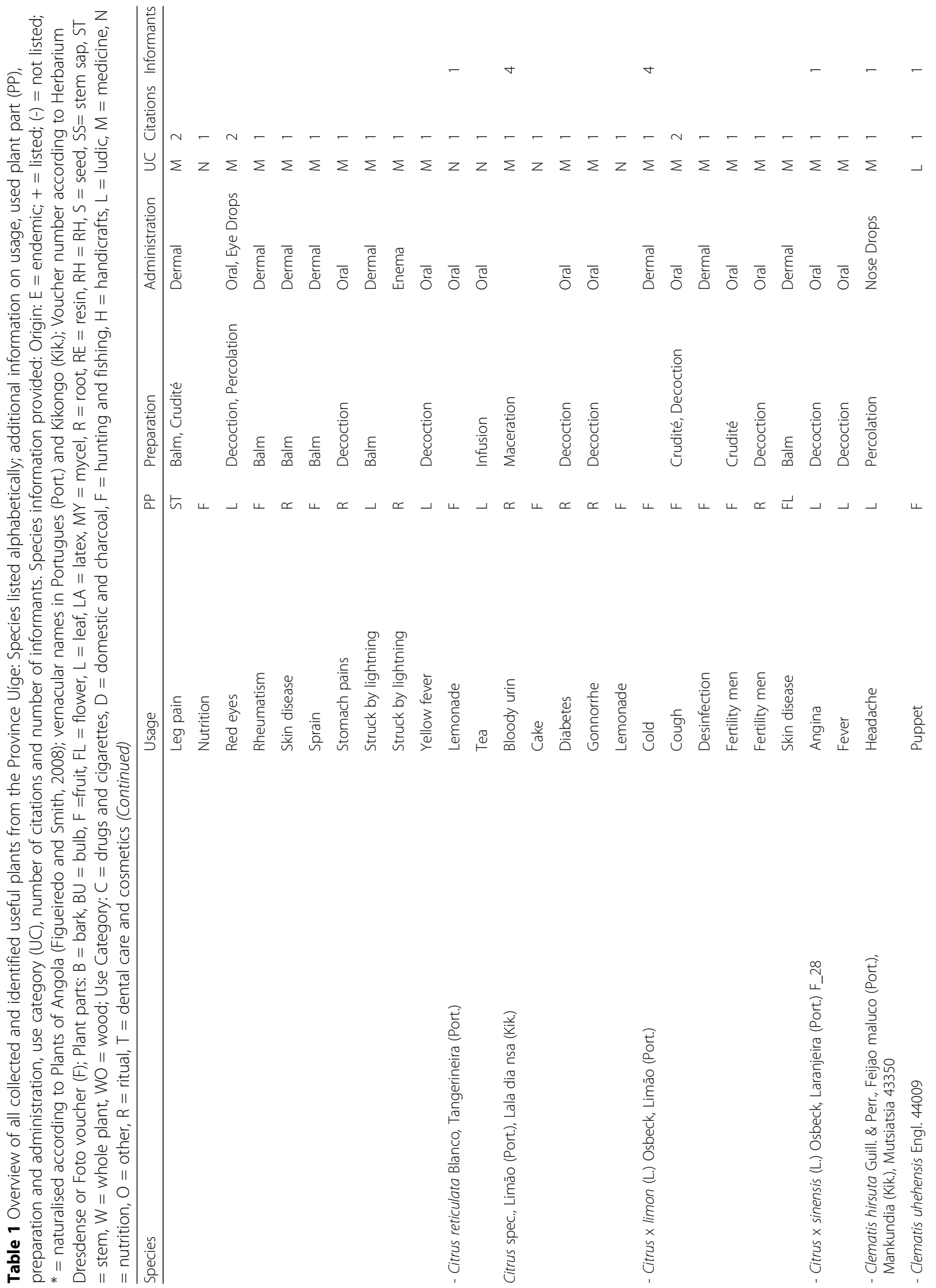




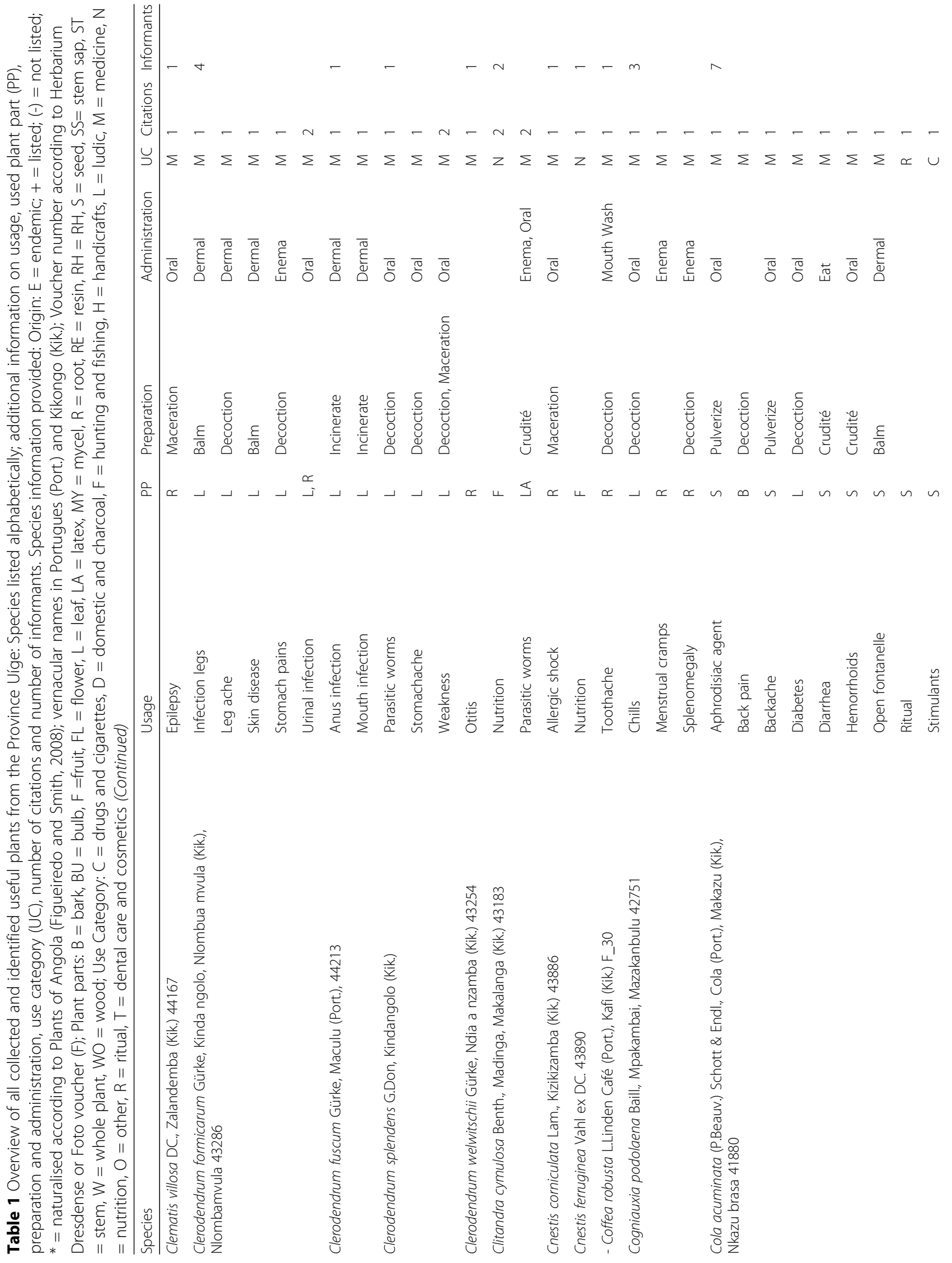




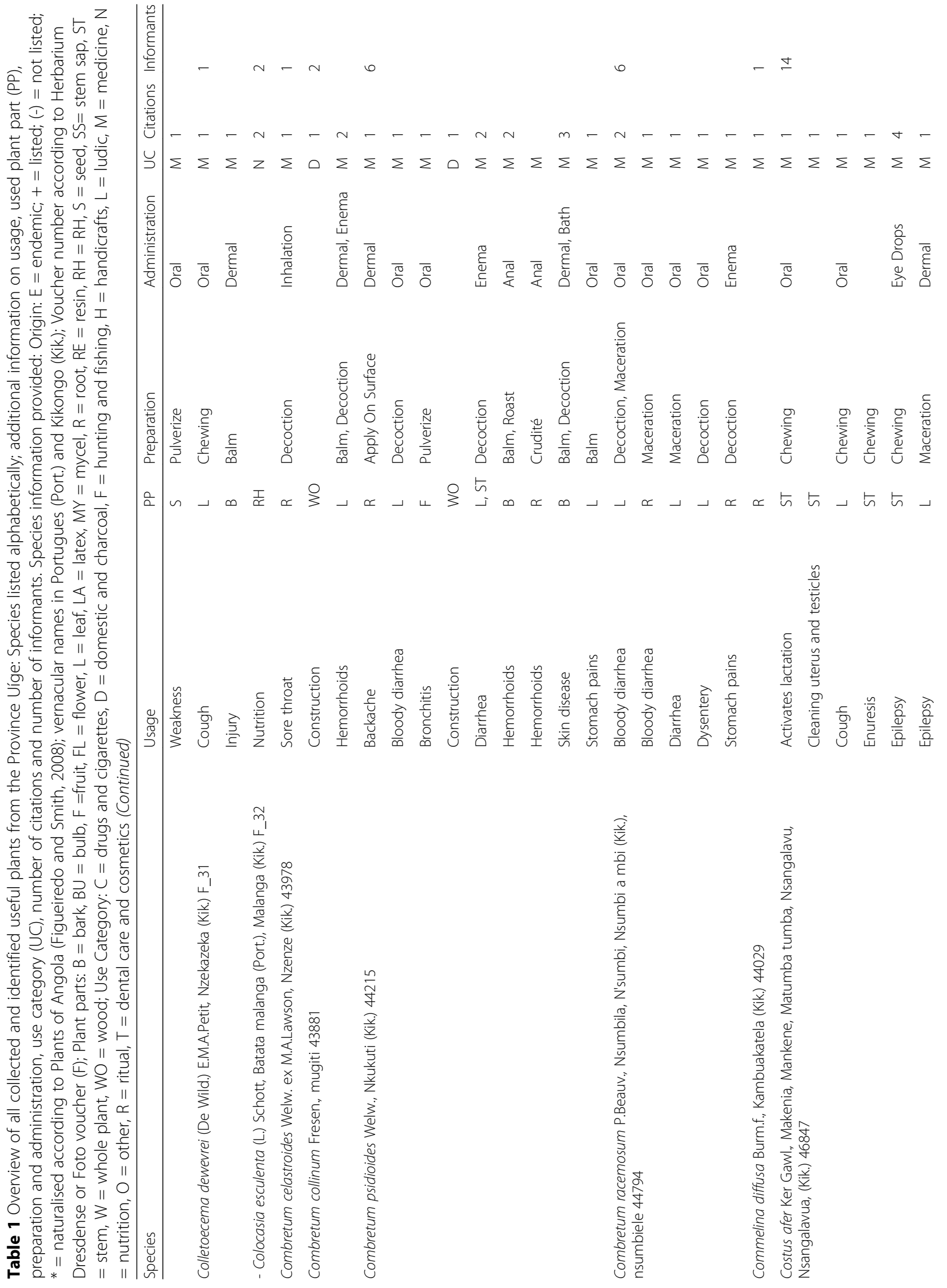




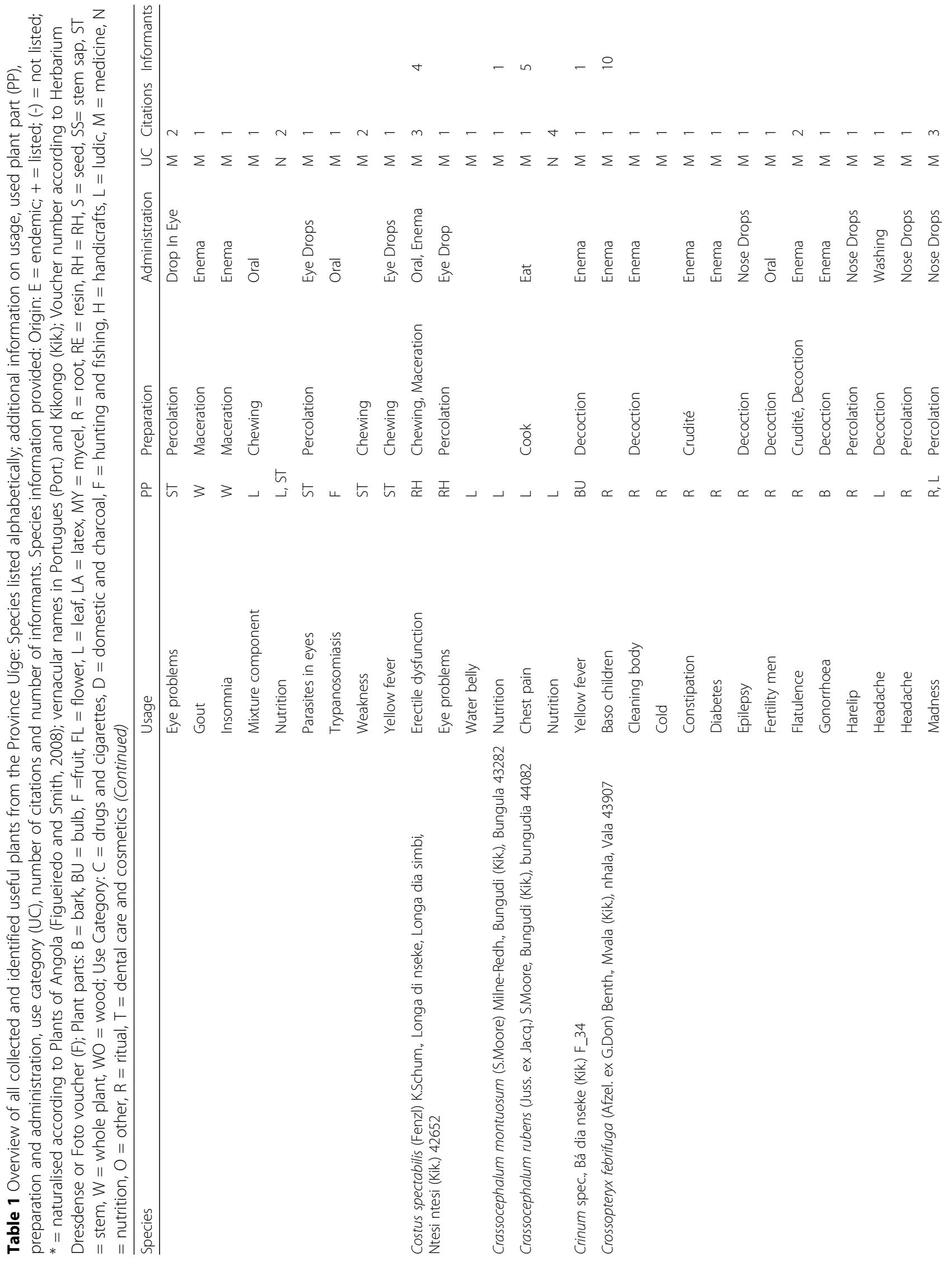




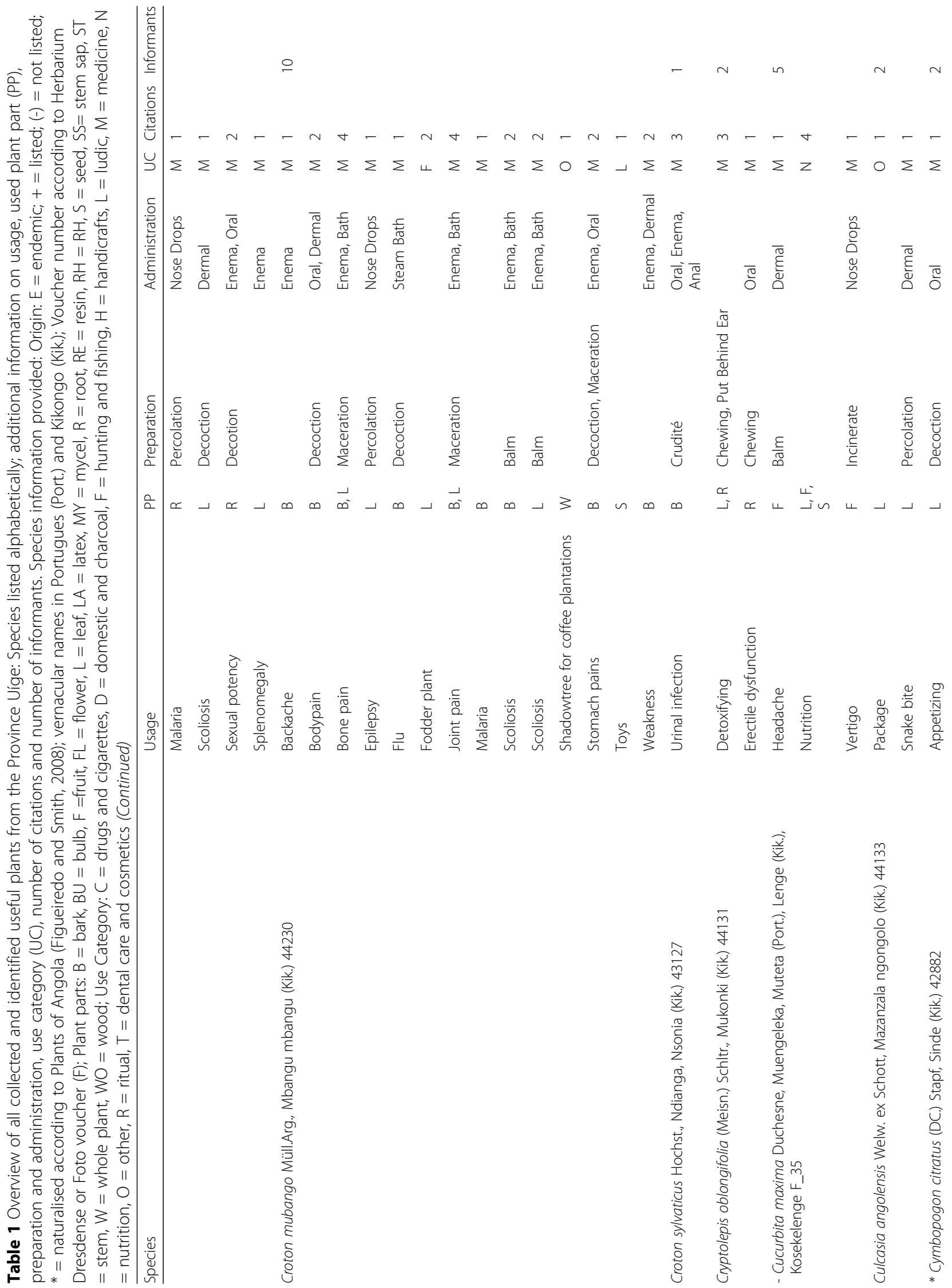




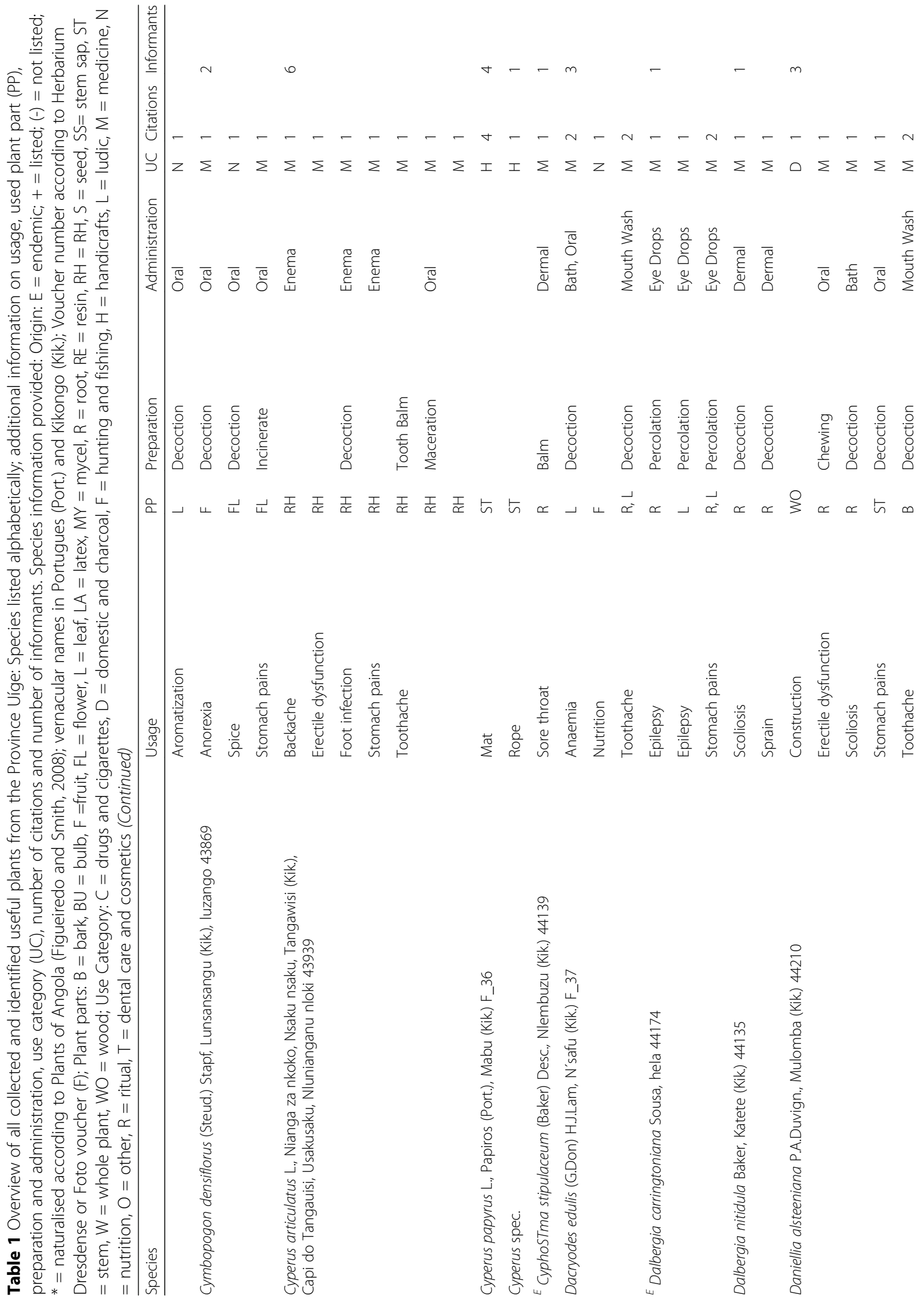




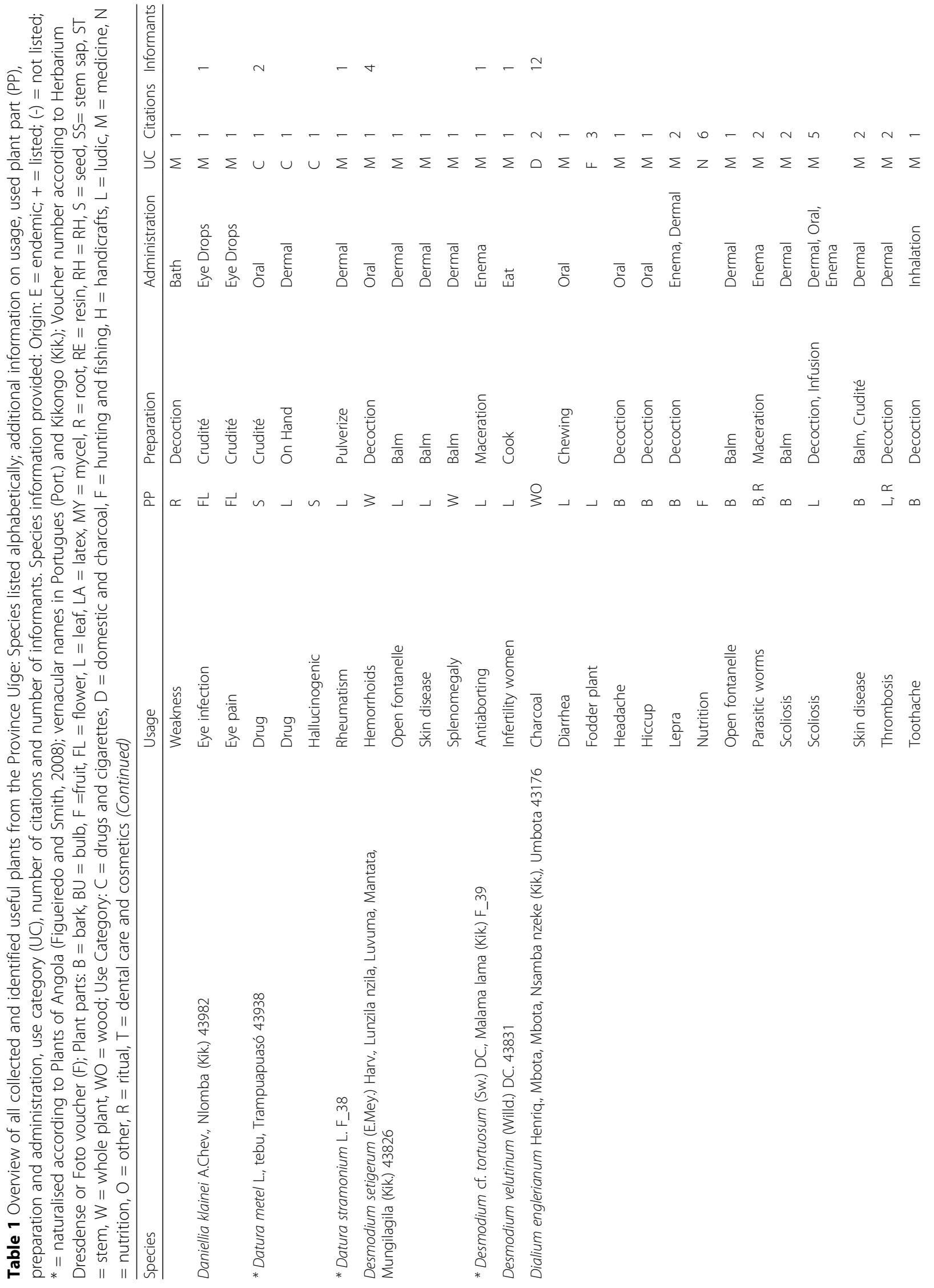




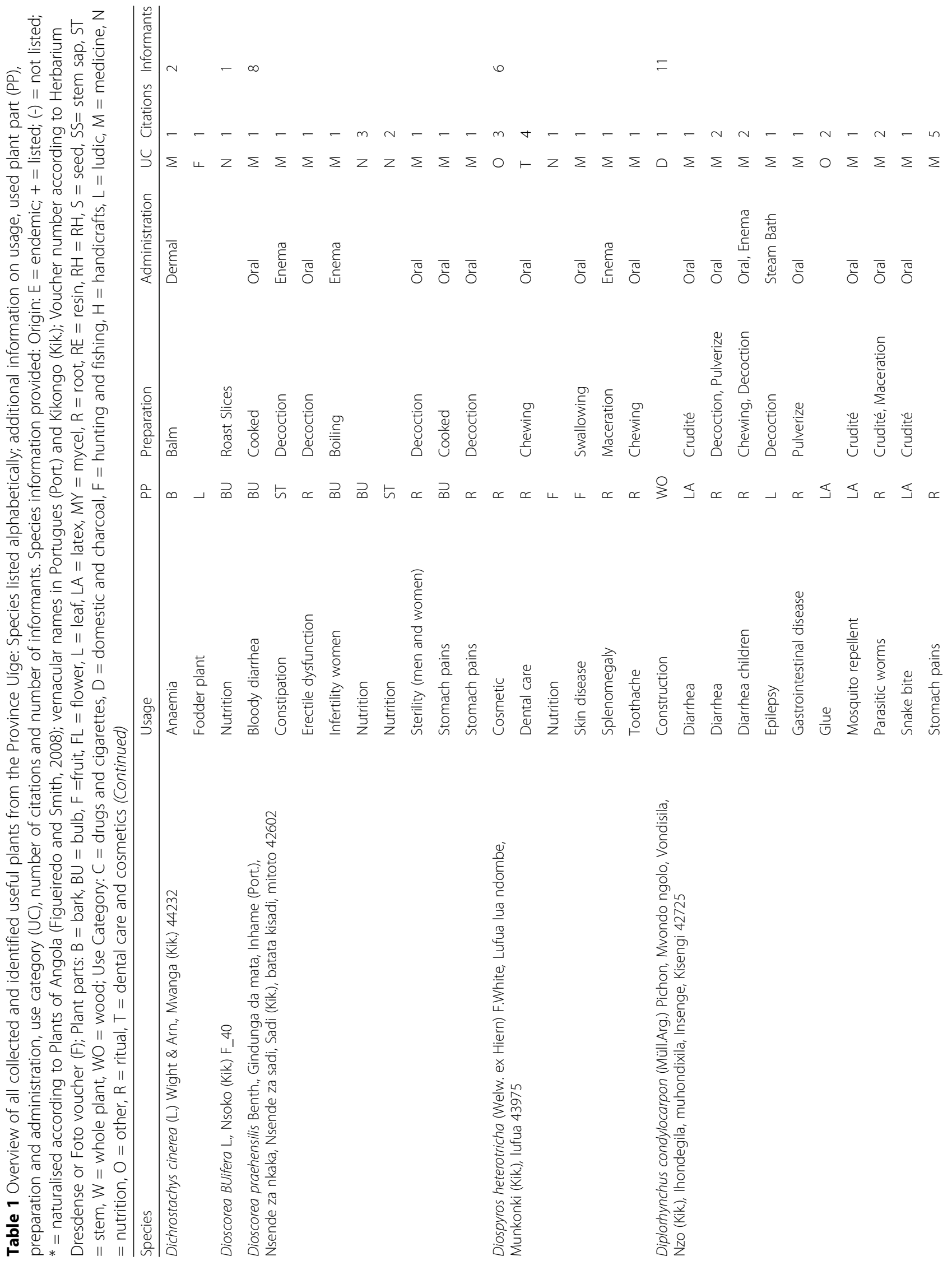




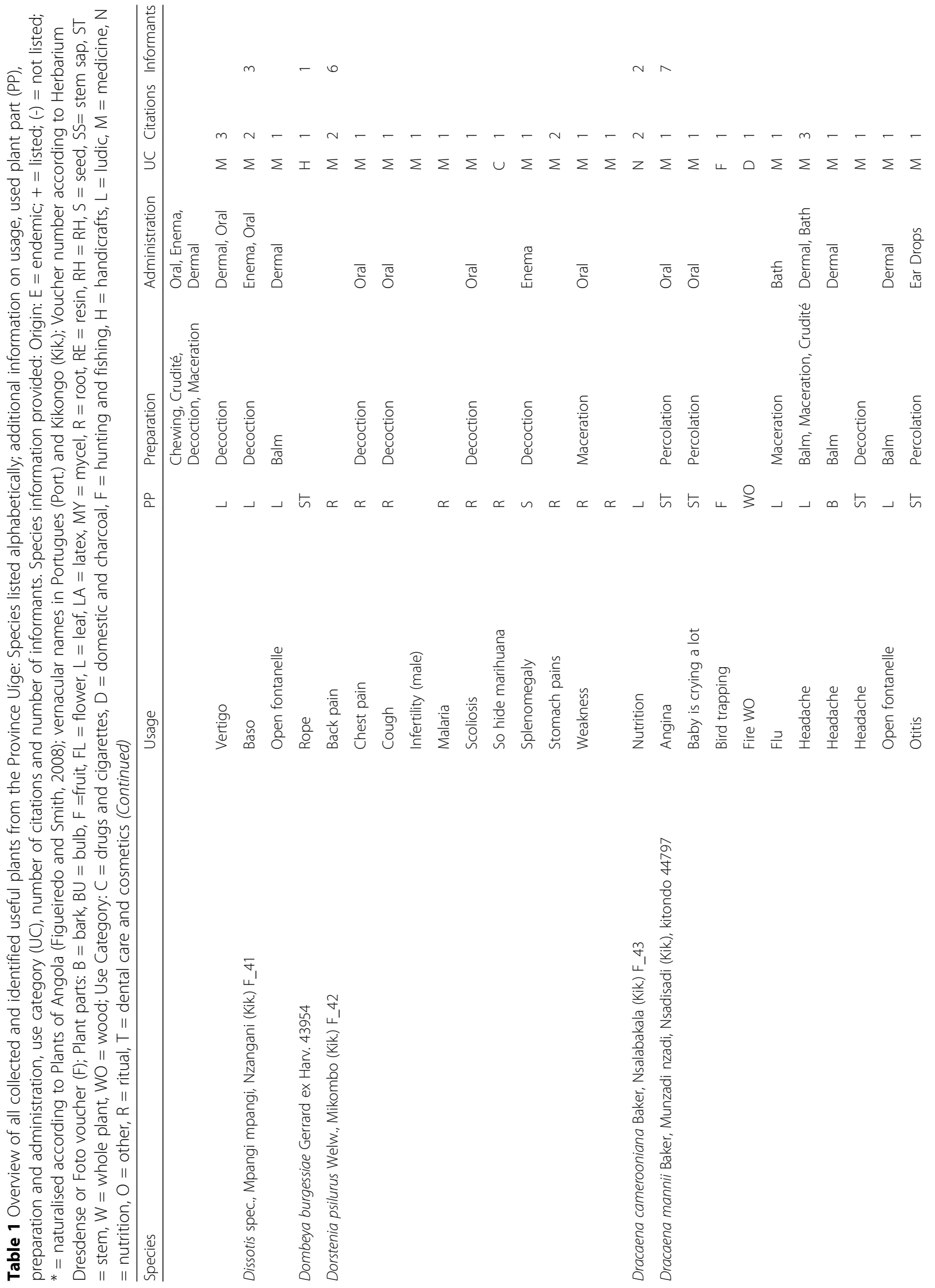




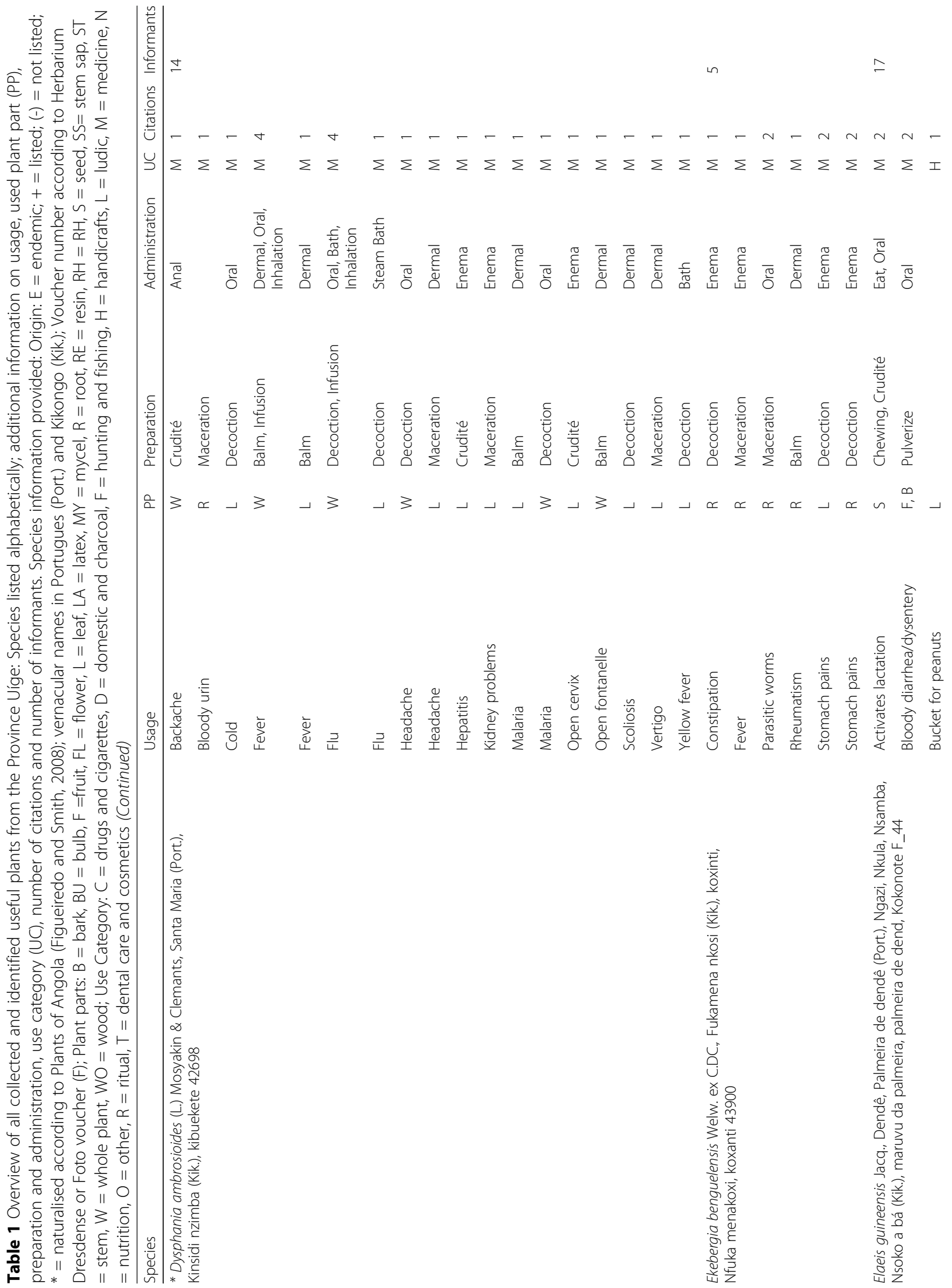




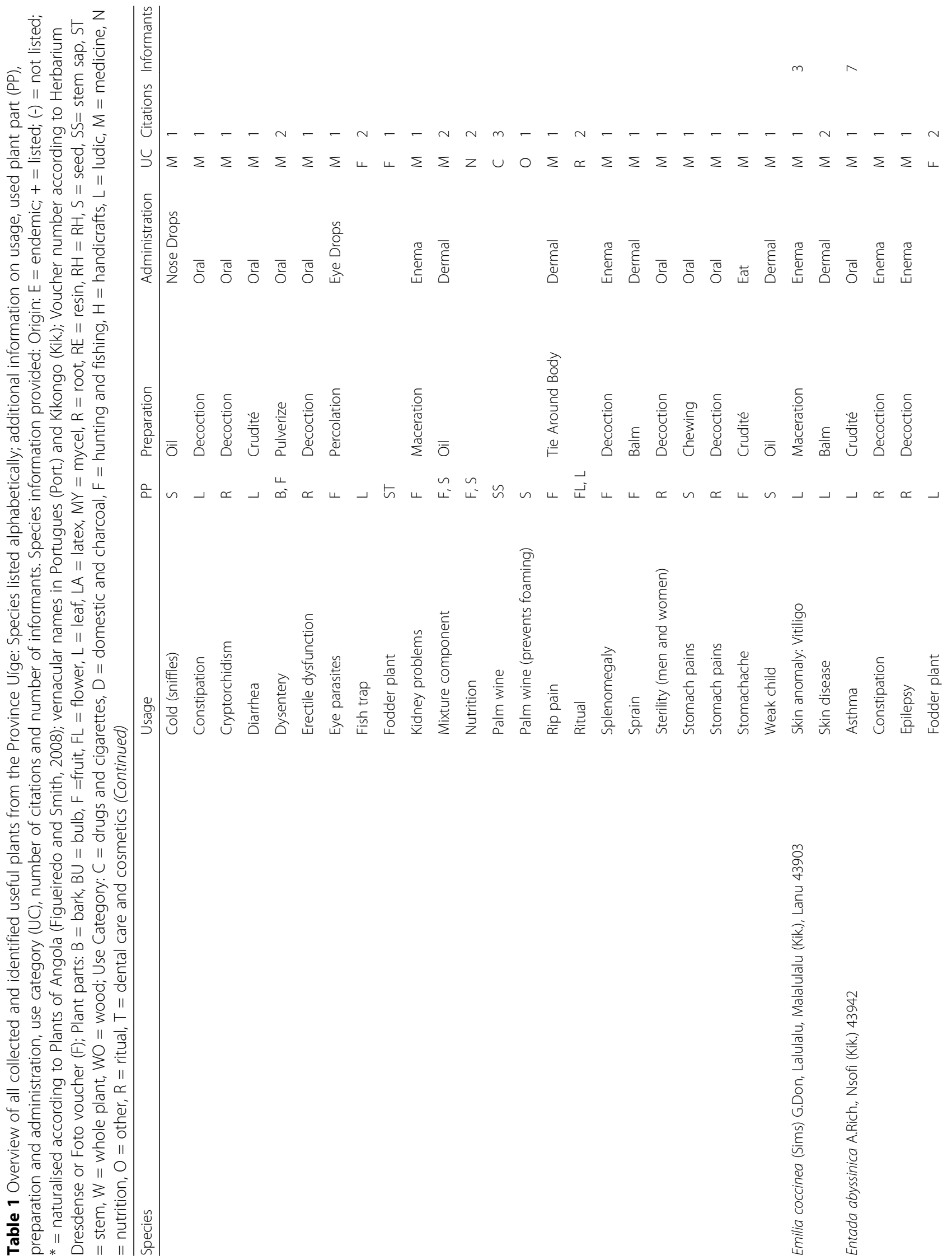




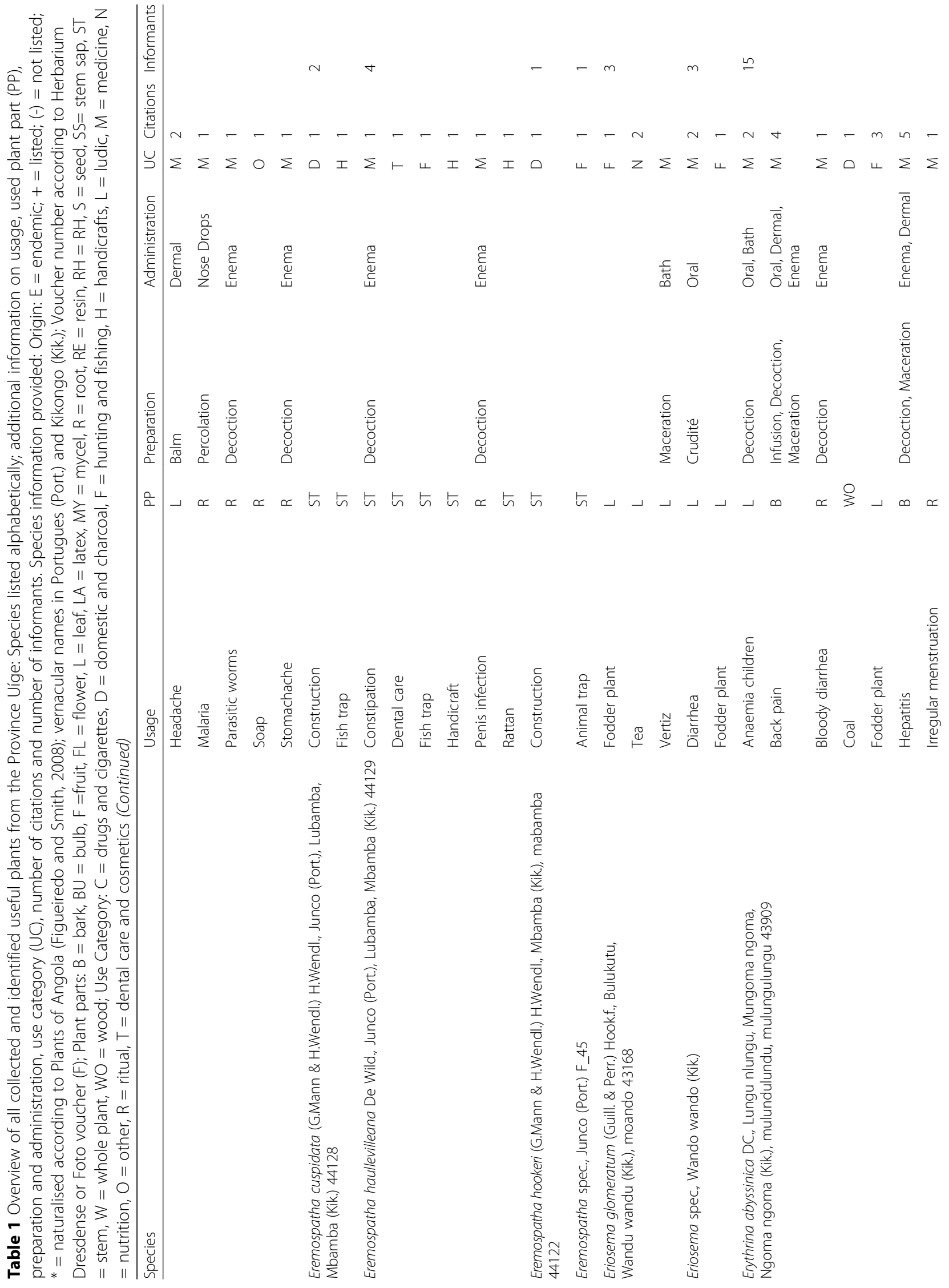




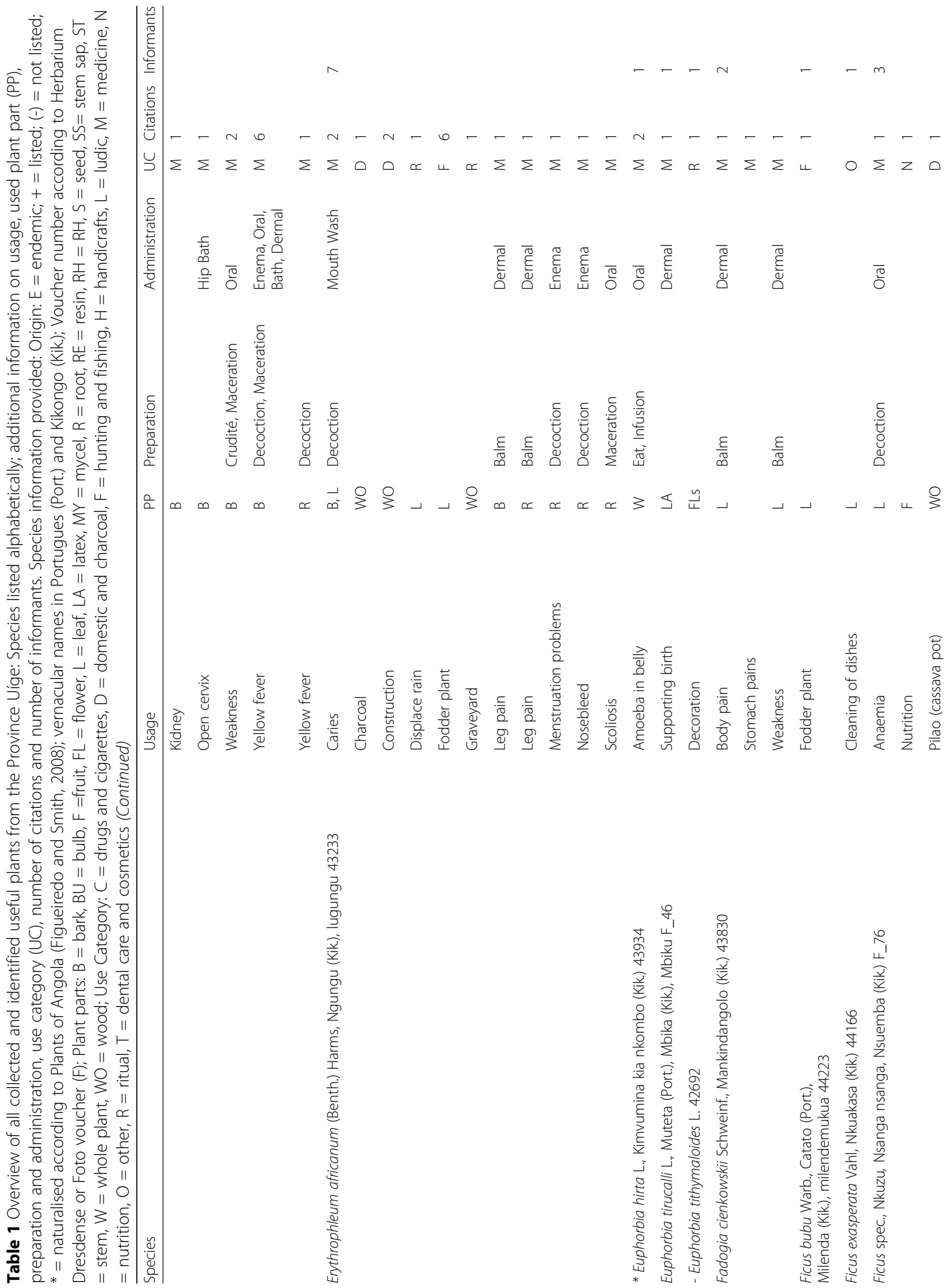




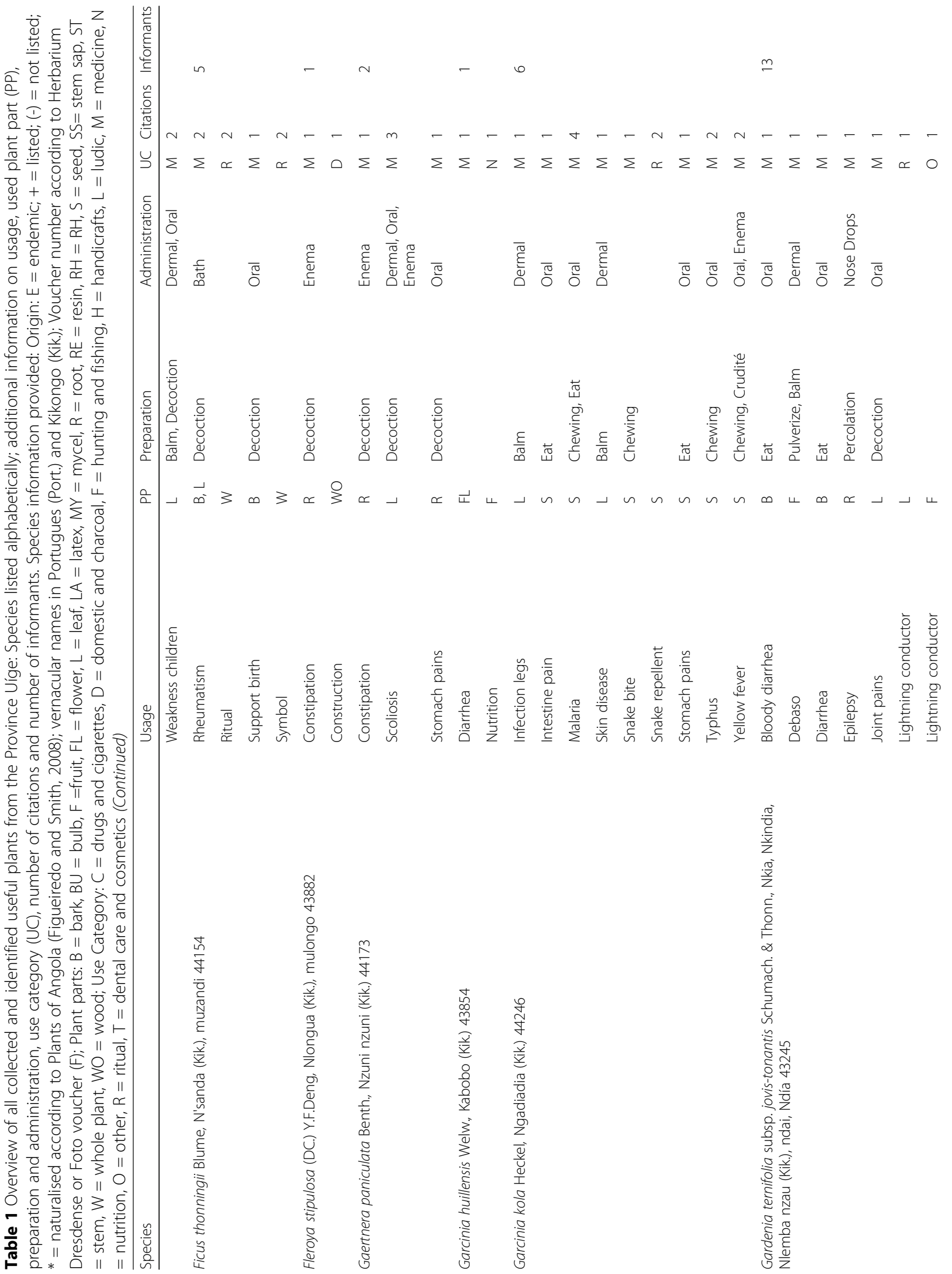




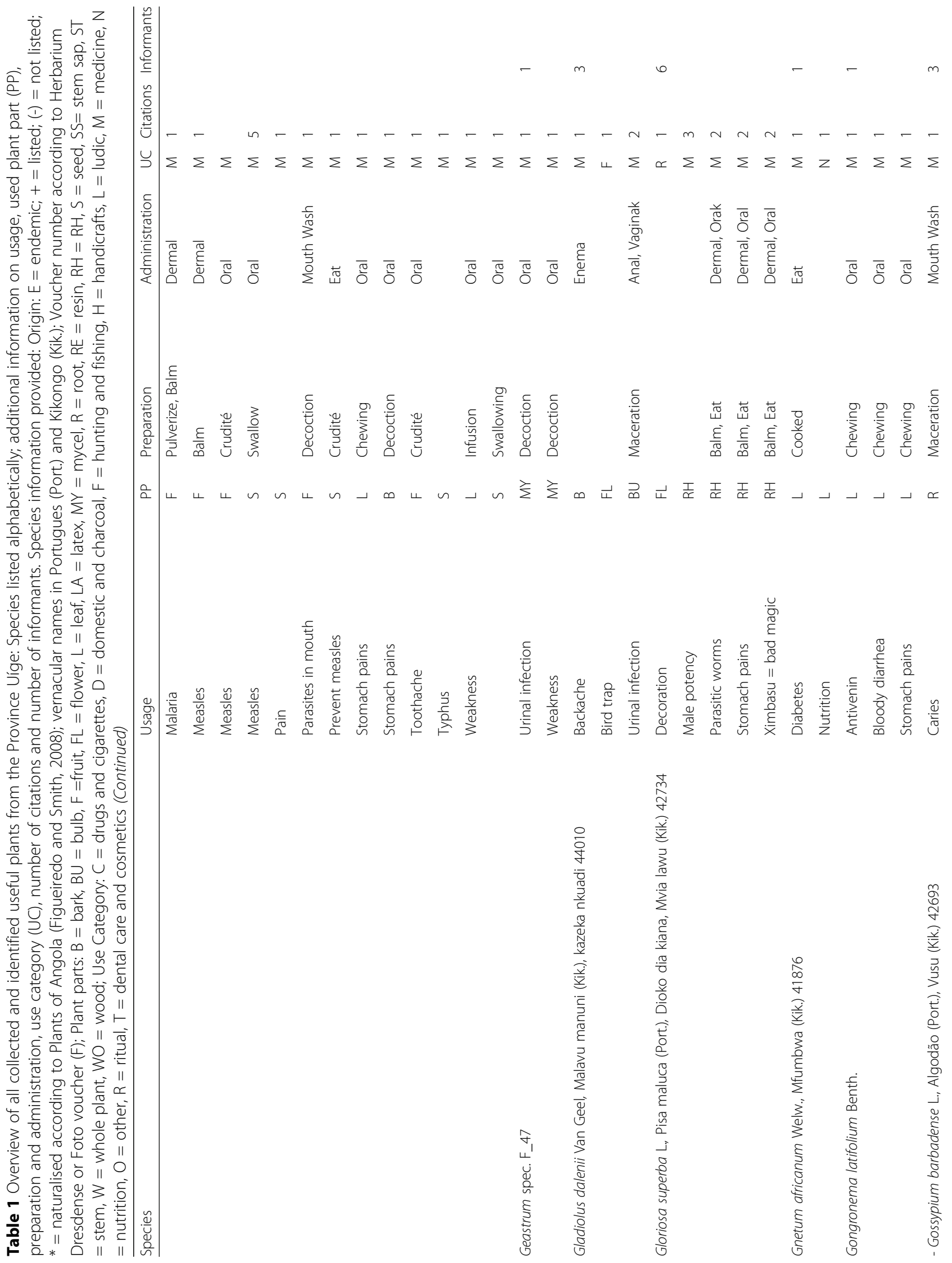




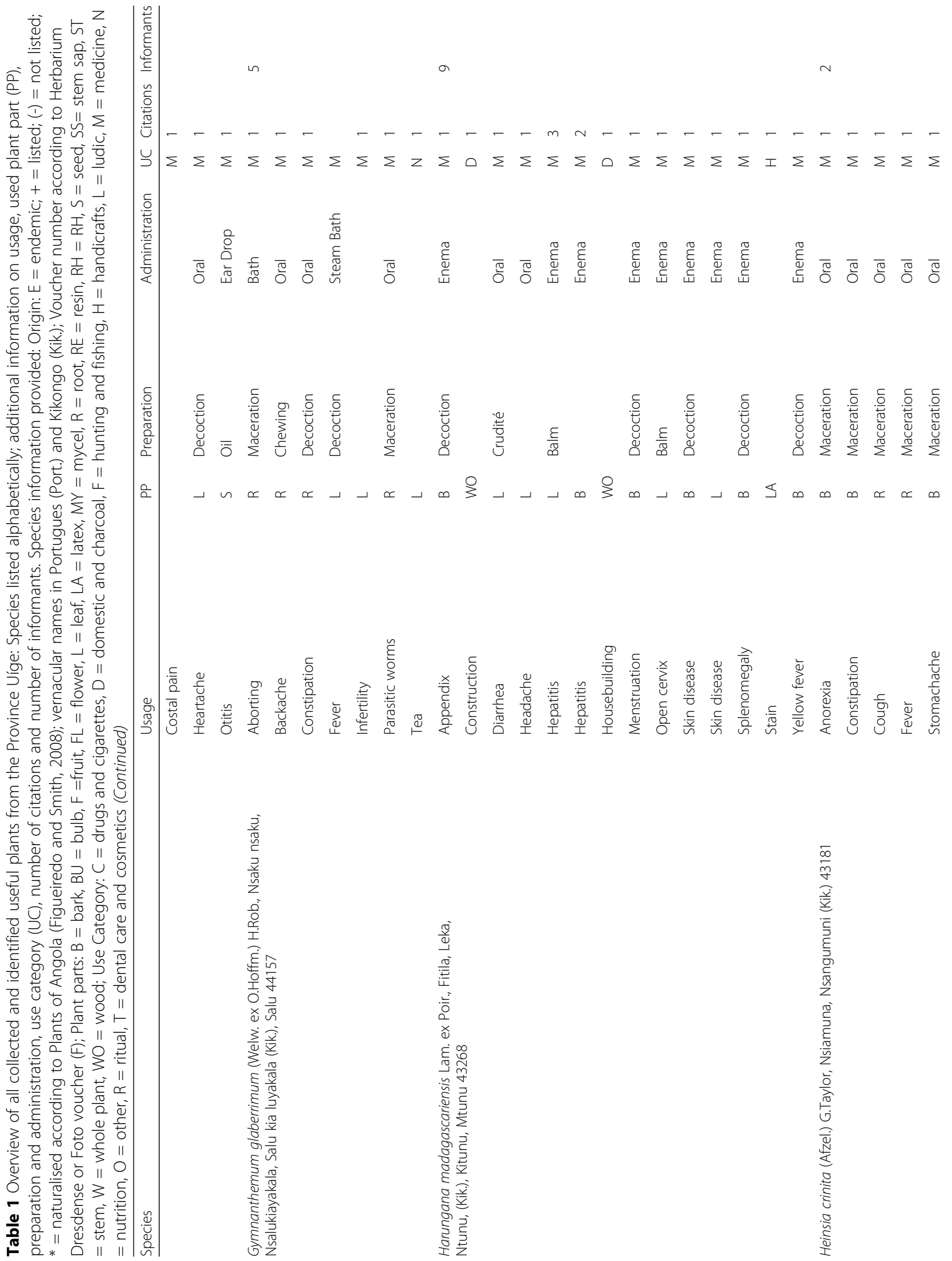




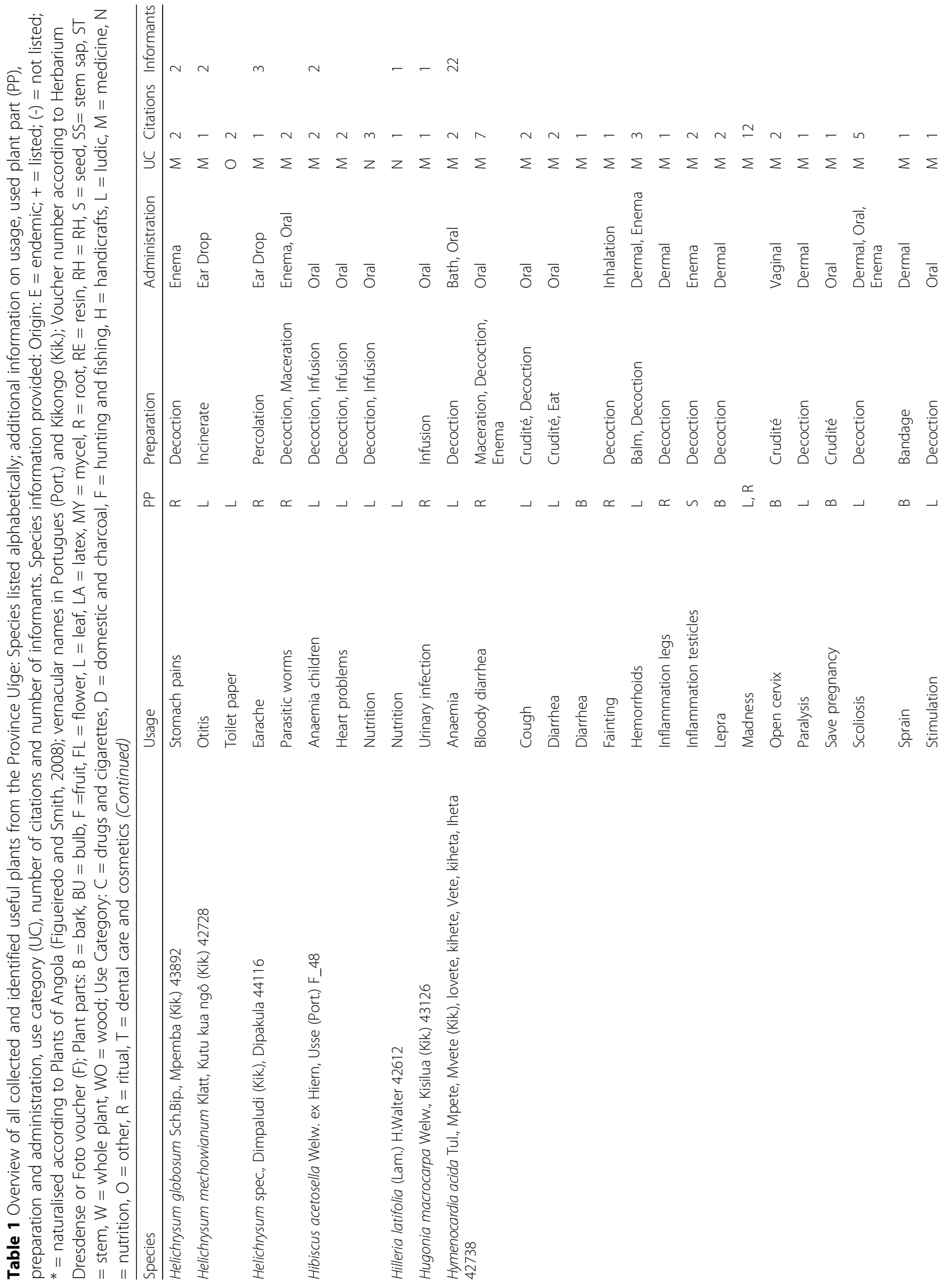




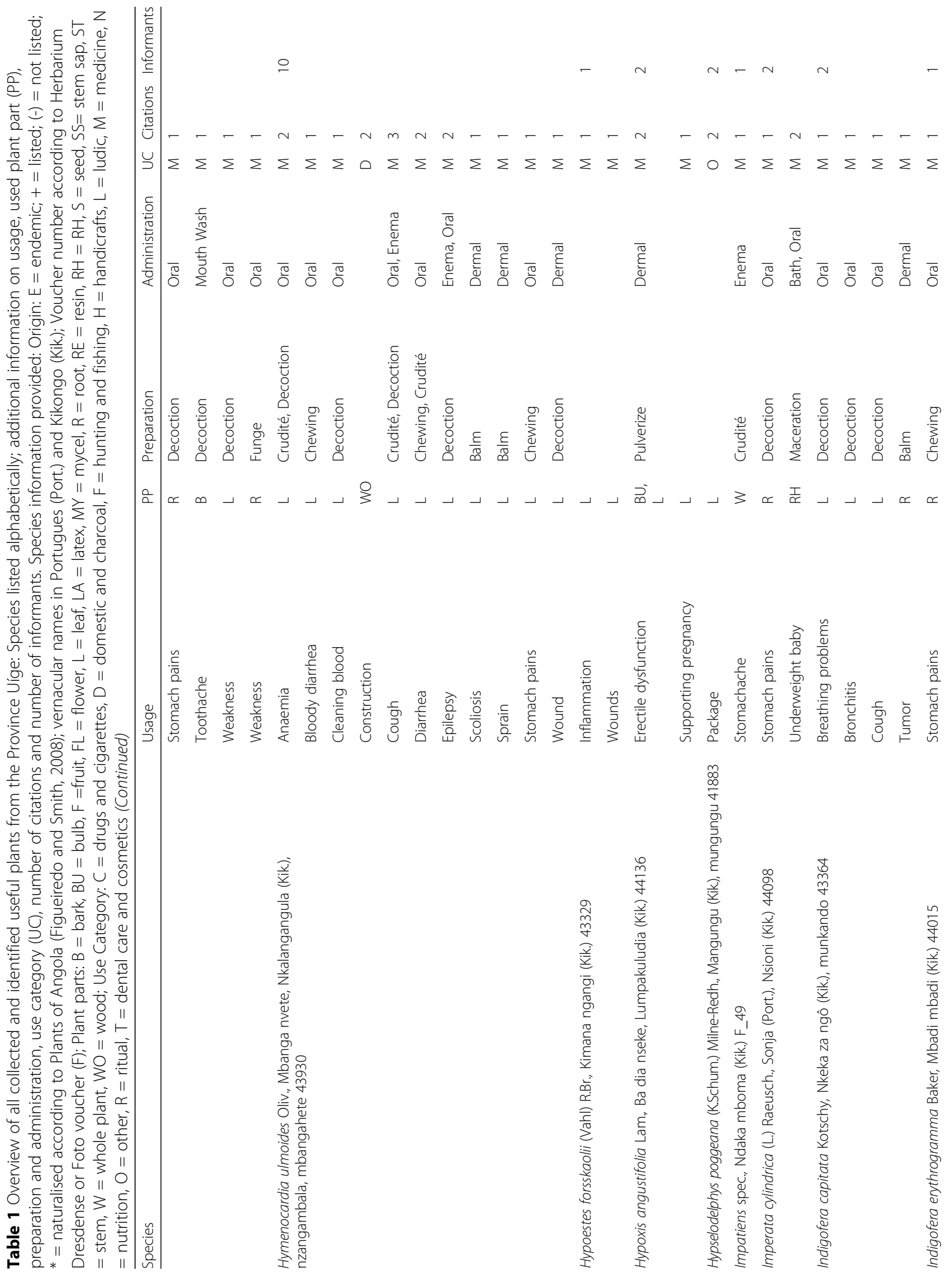




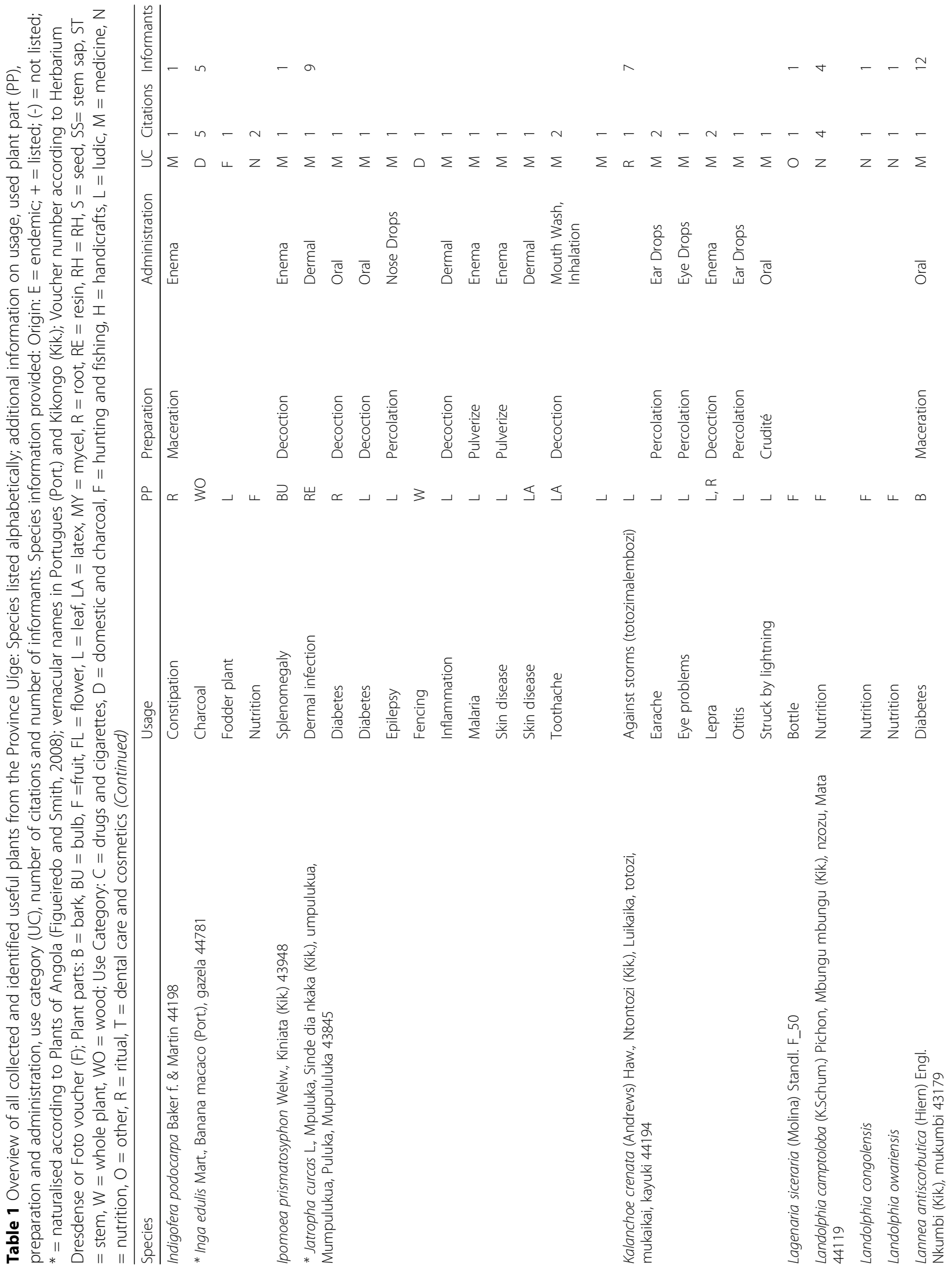




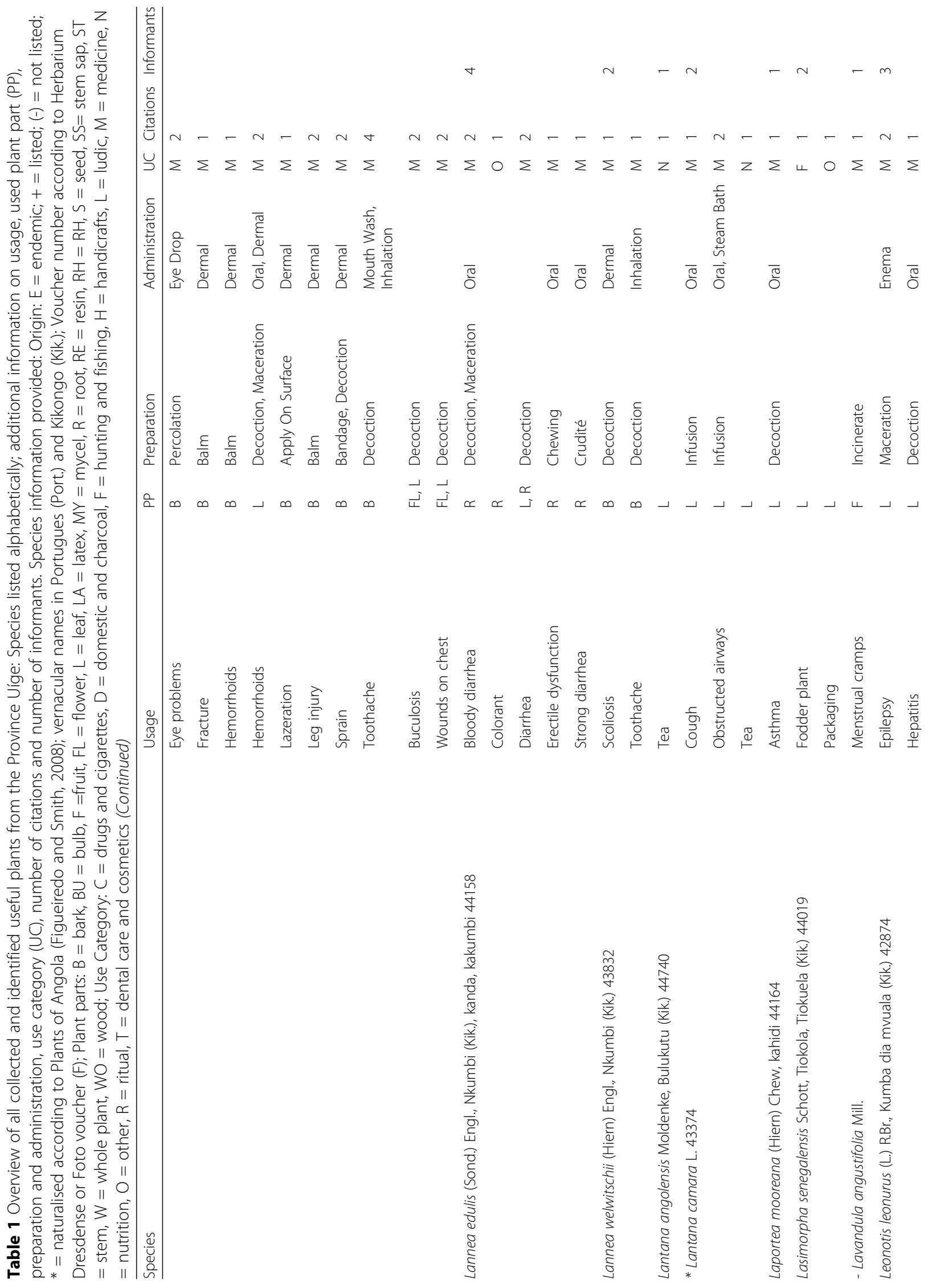




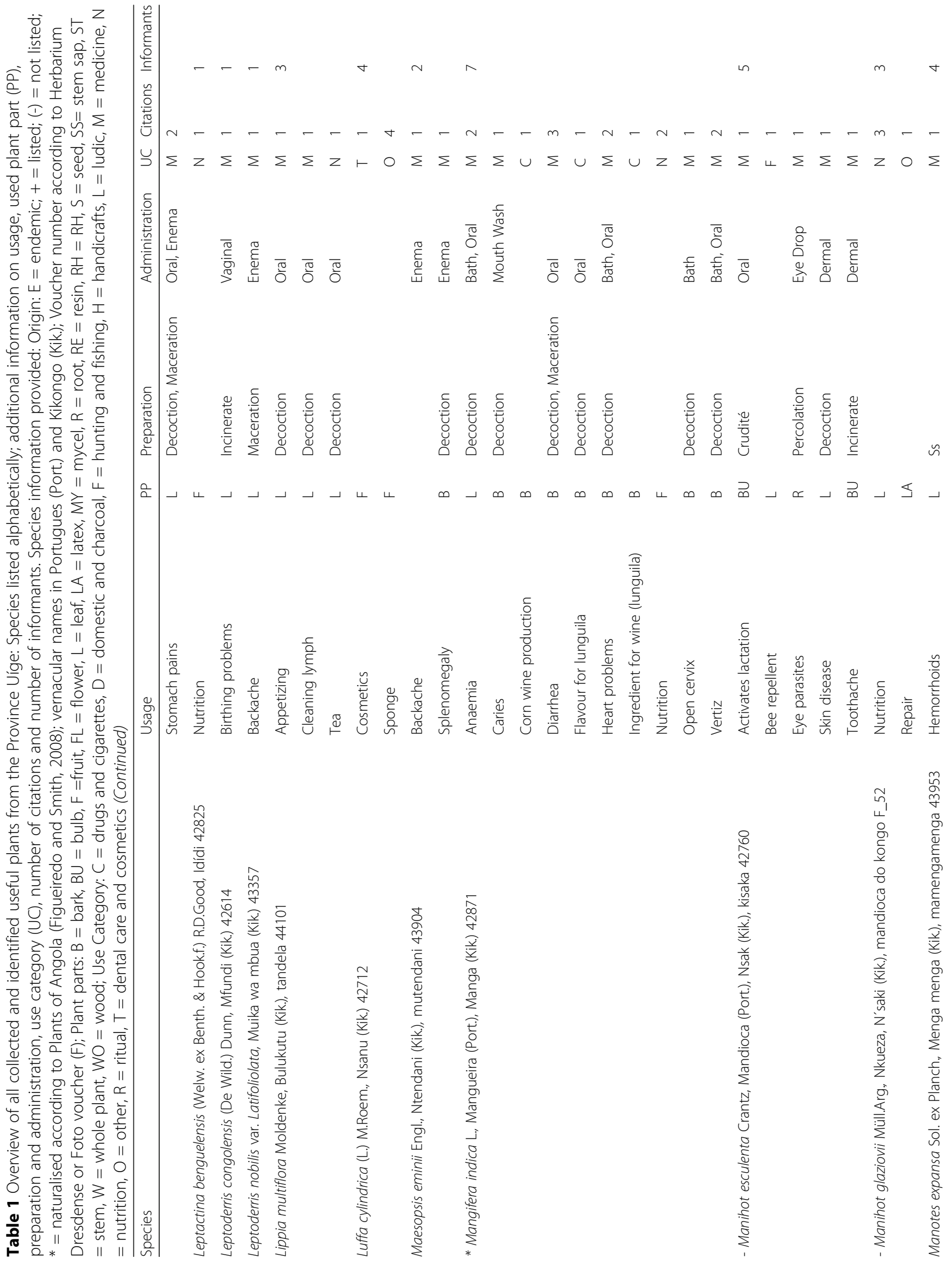




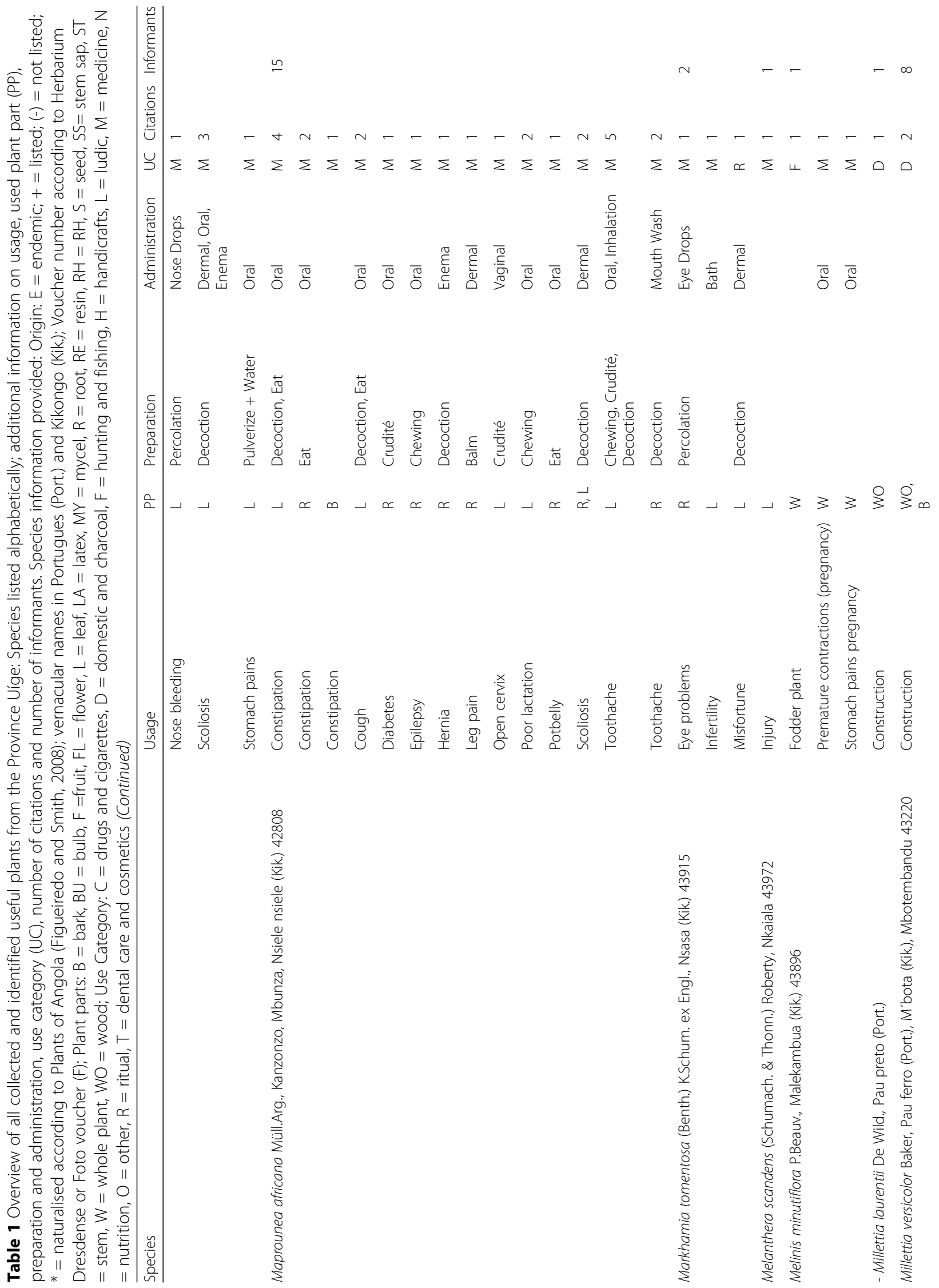




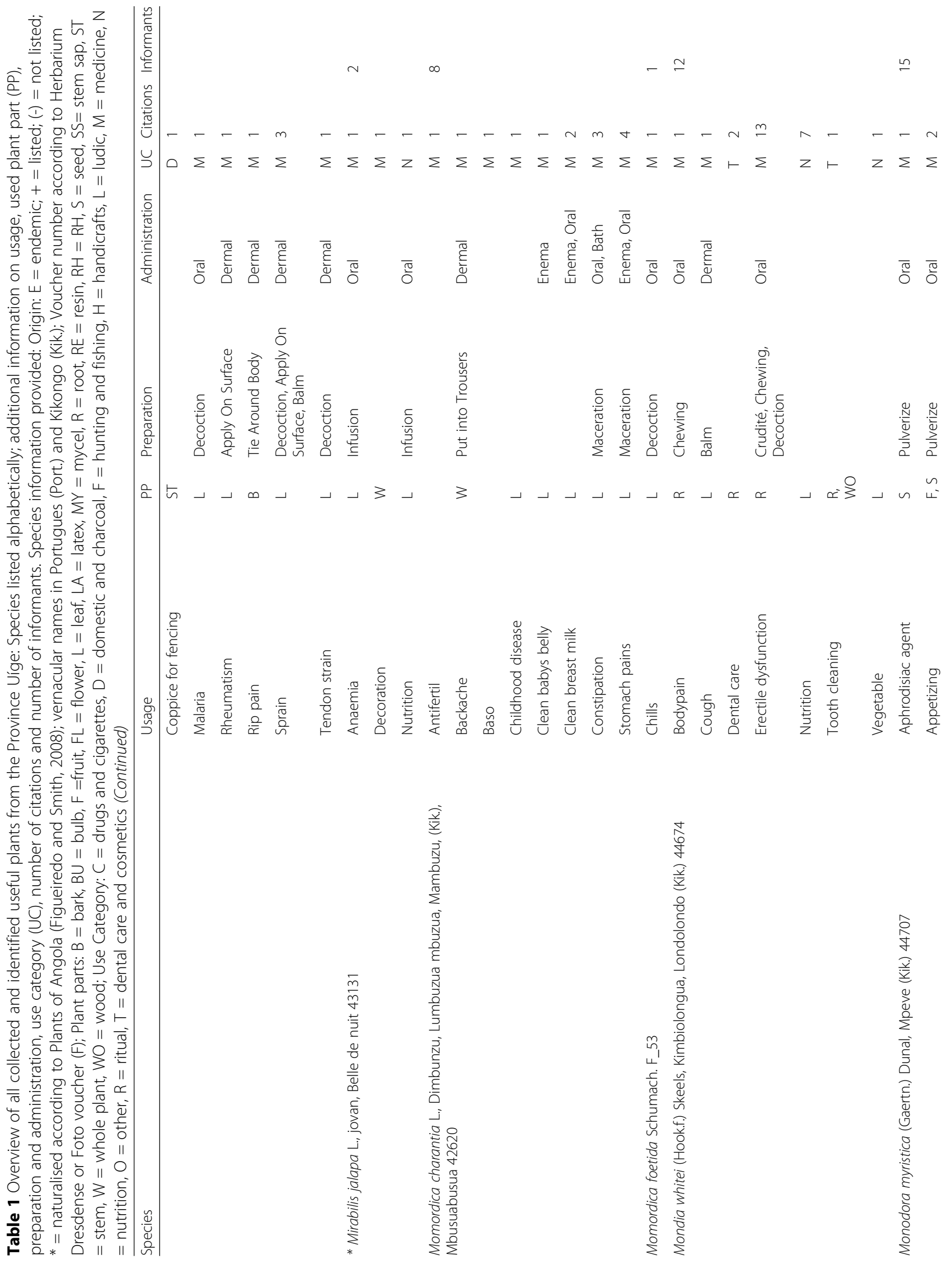




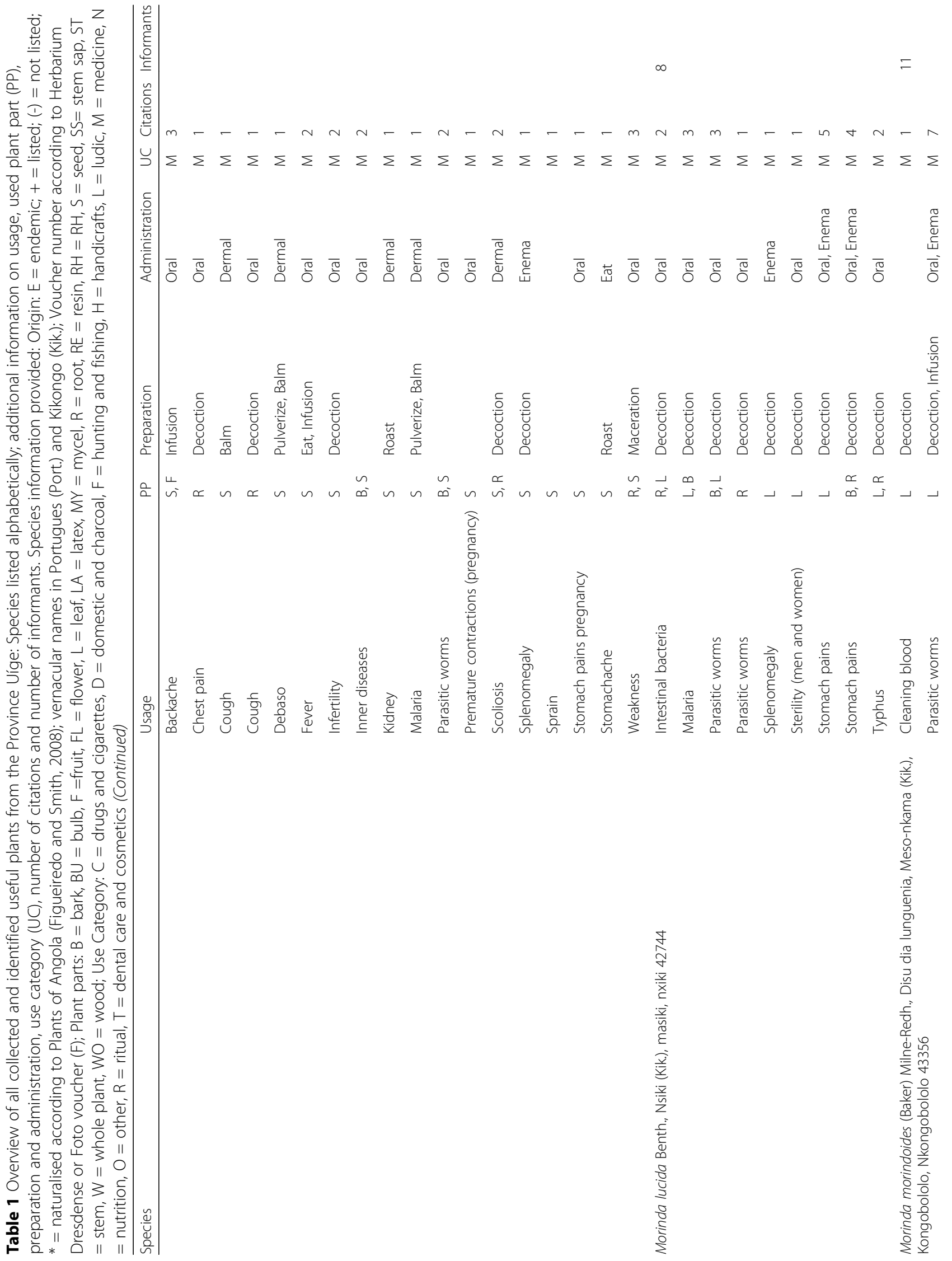




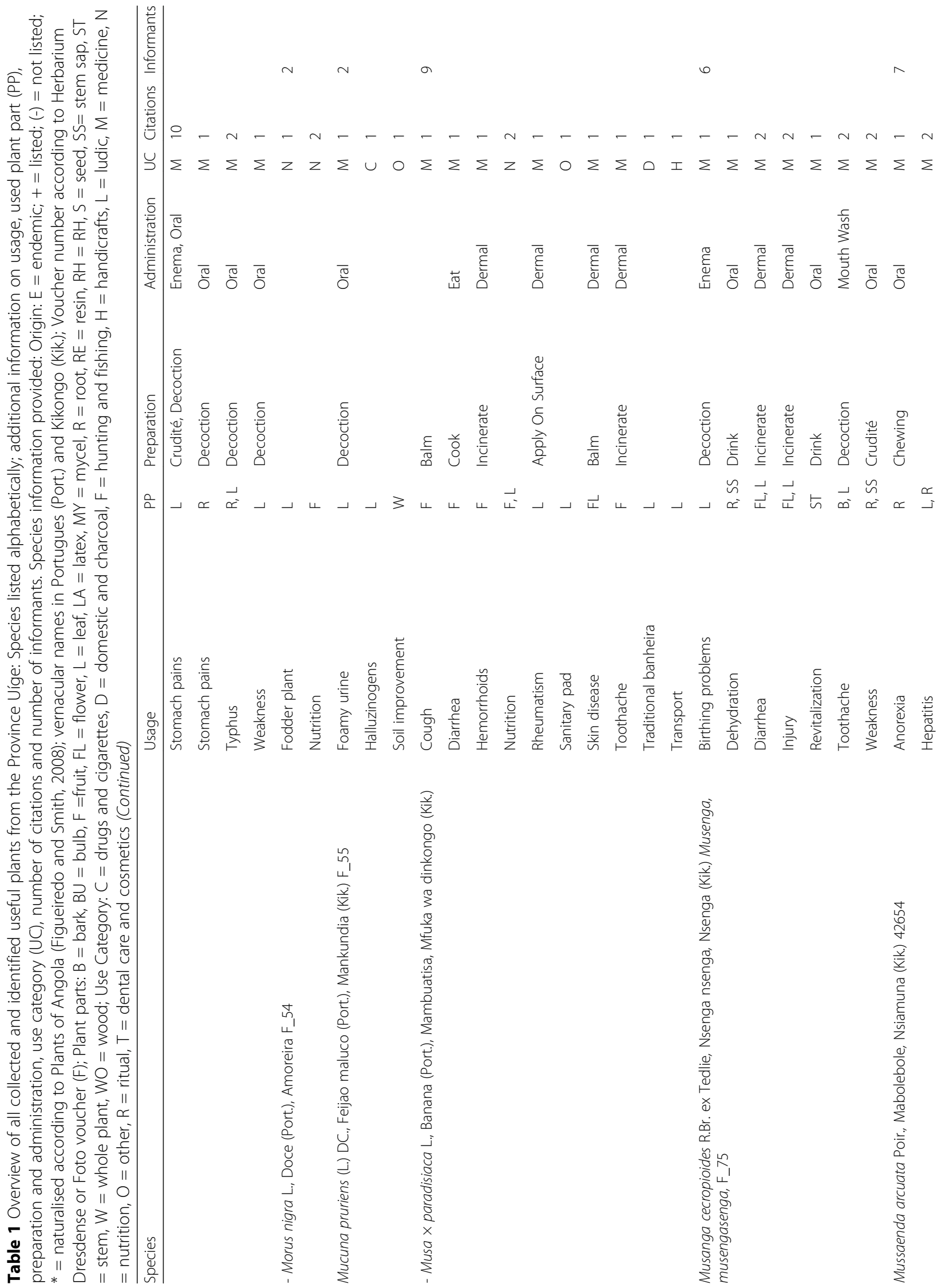


Lautenschläger et al. Journal of Ethnobiology and Ethnomedicine (2018) 14:51

Page 42 of 73

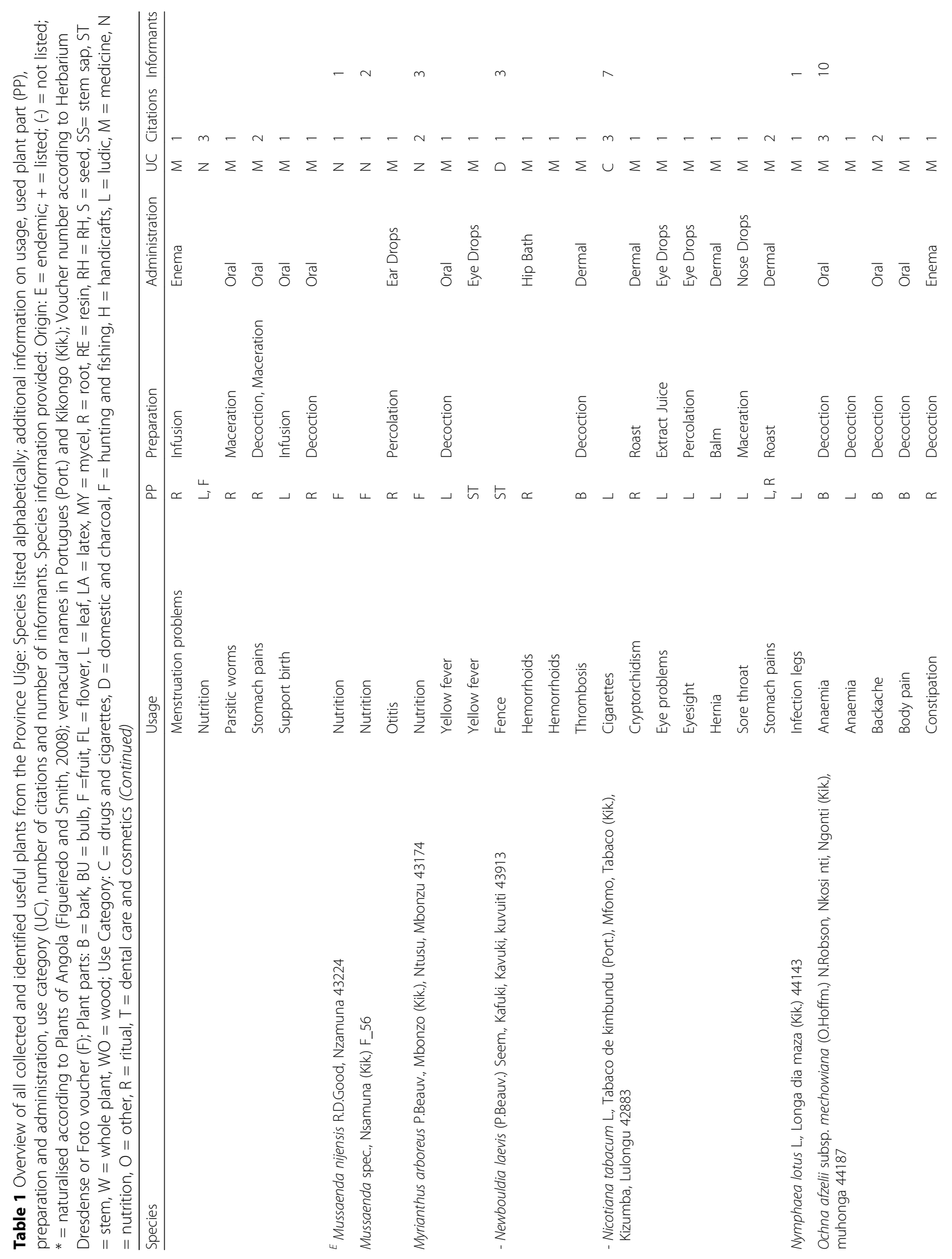




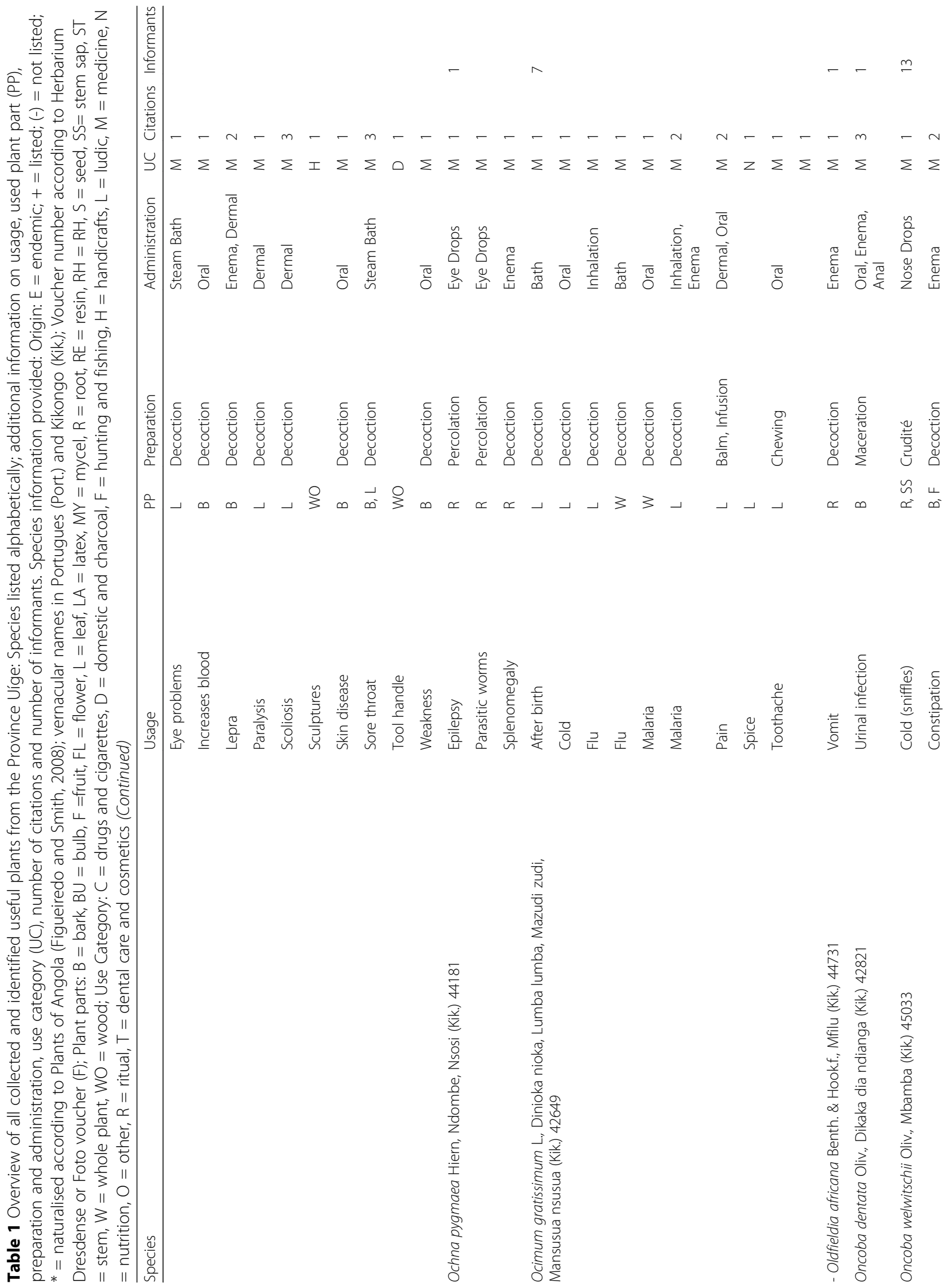




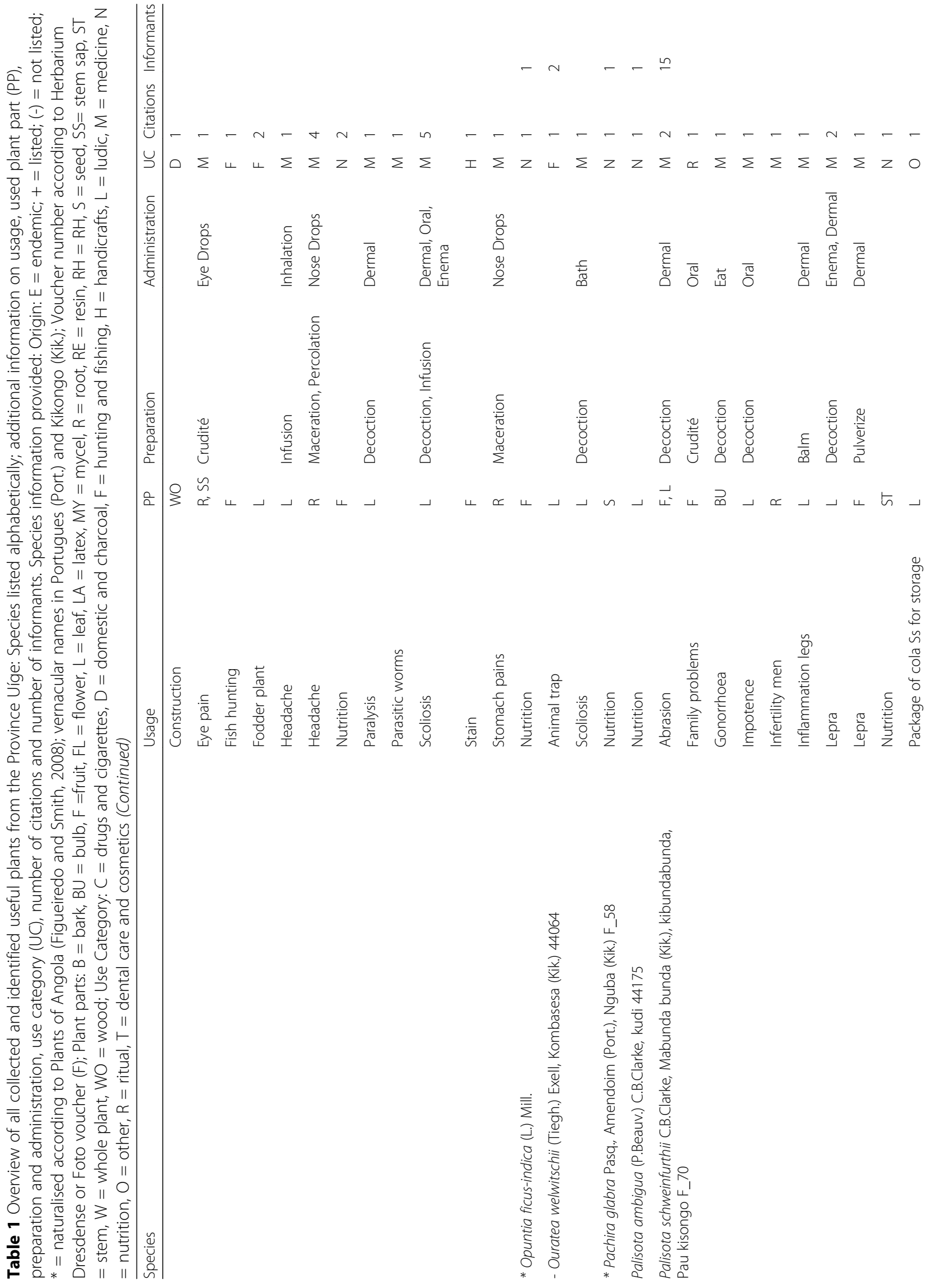




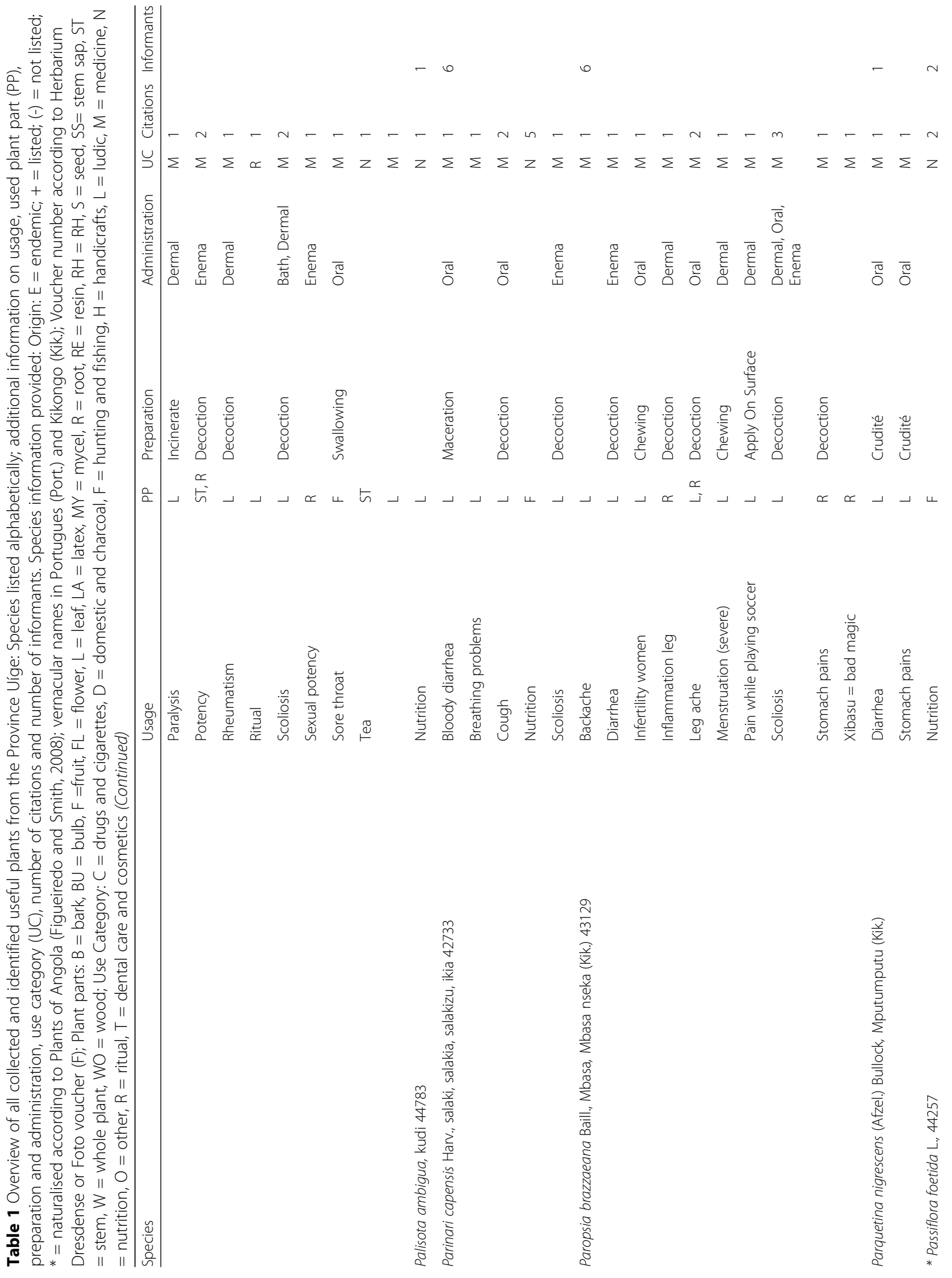




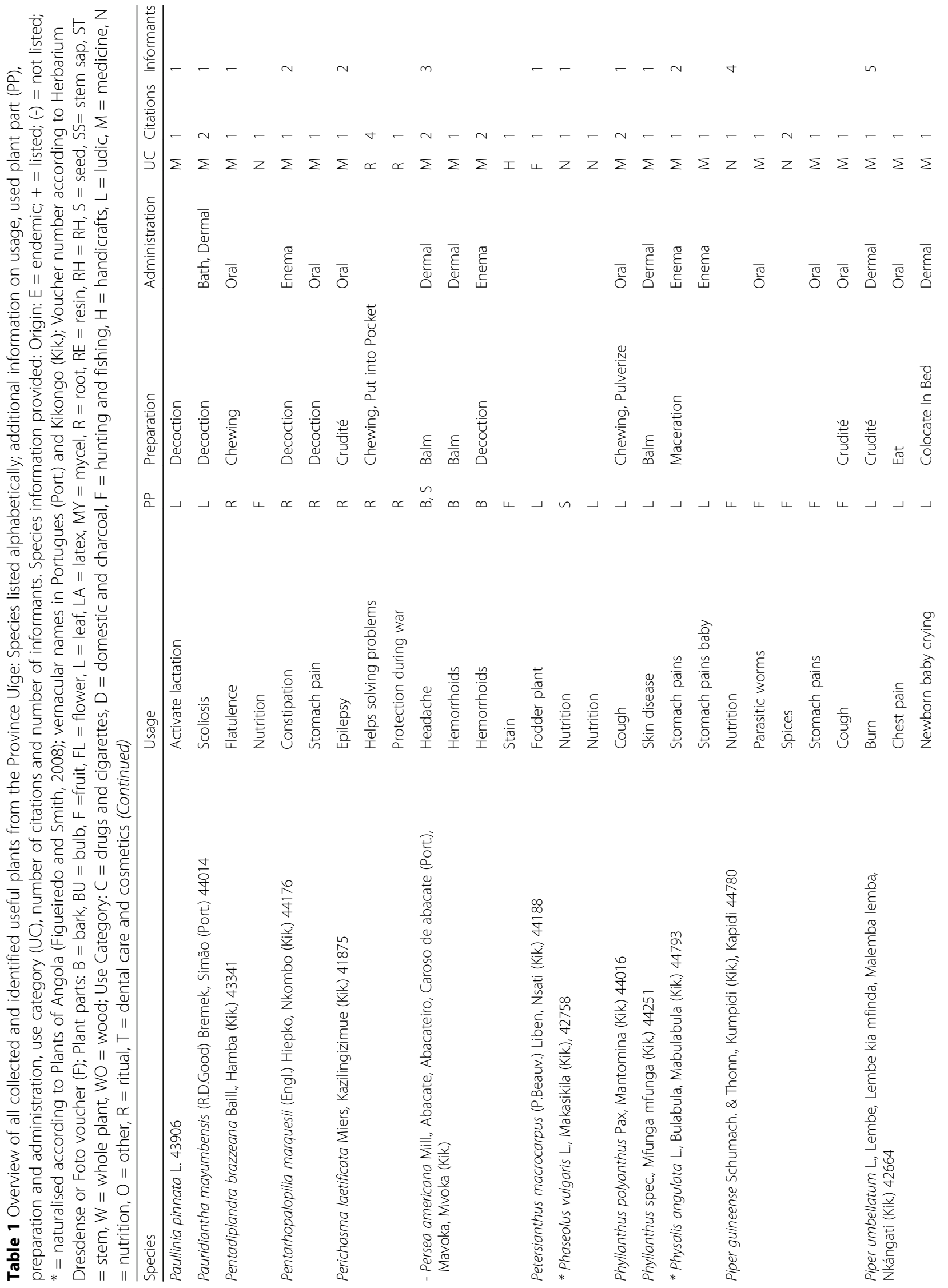




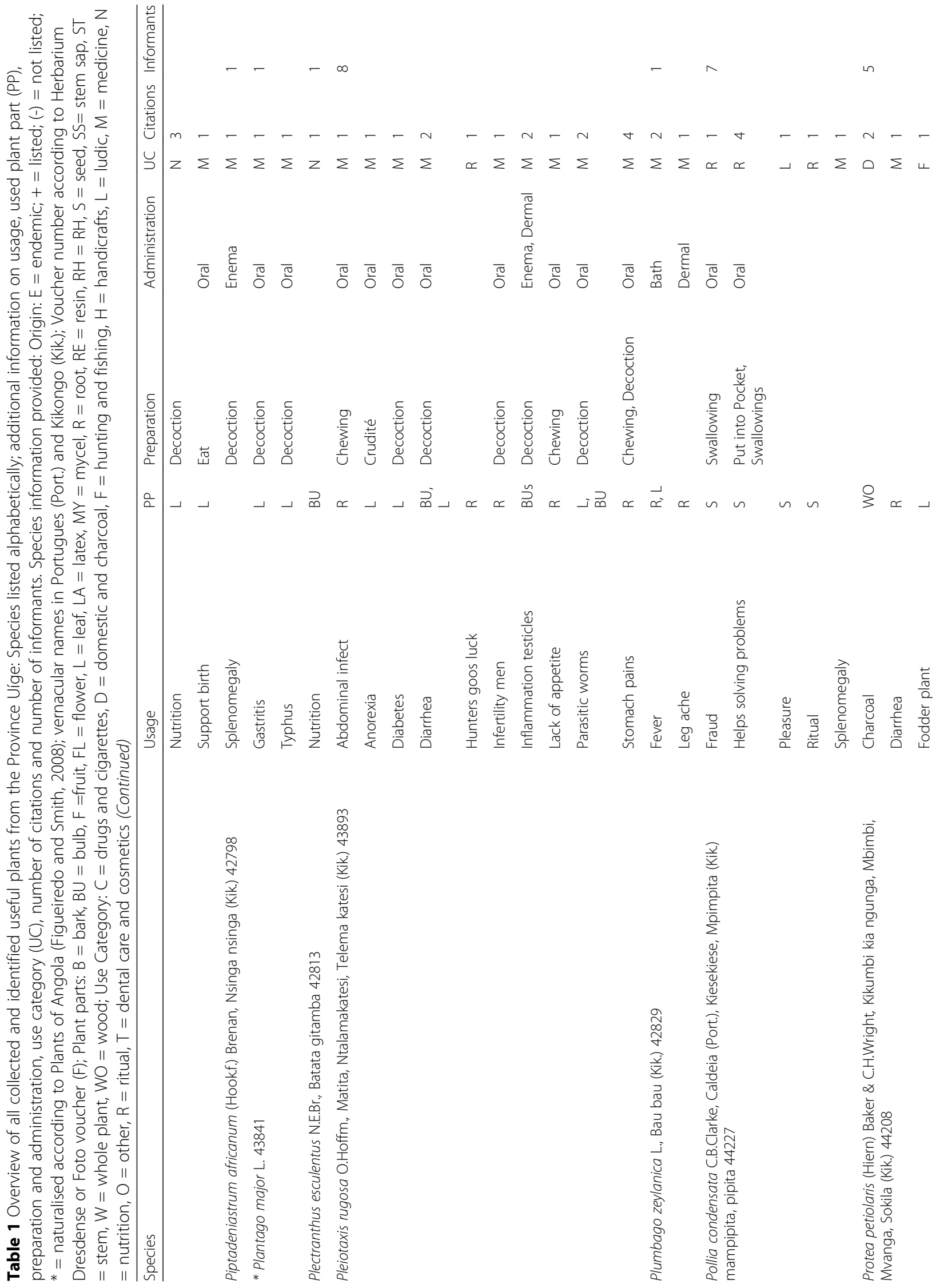




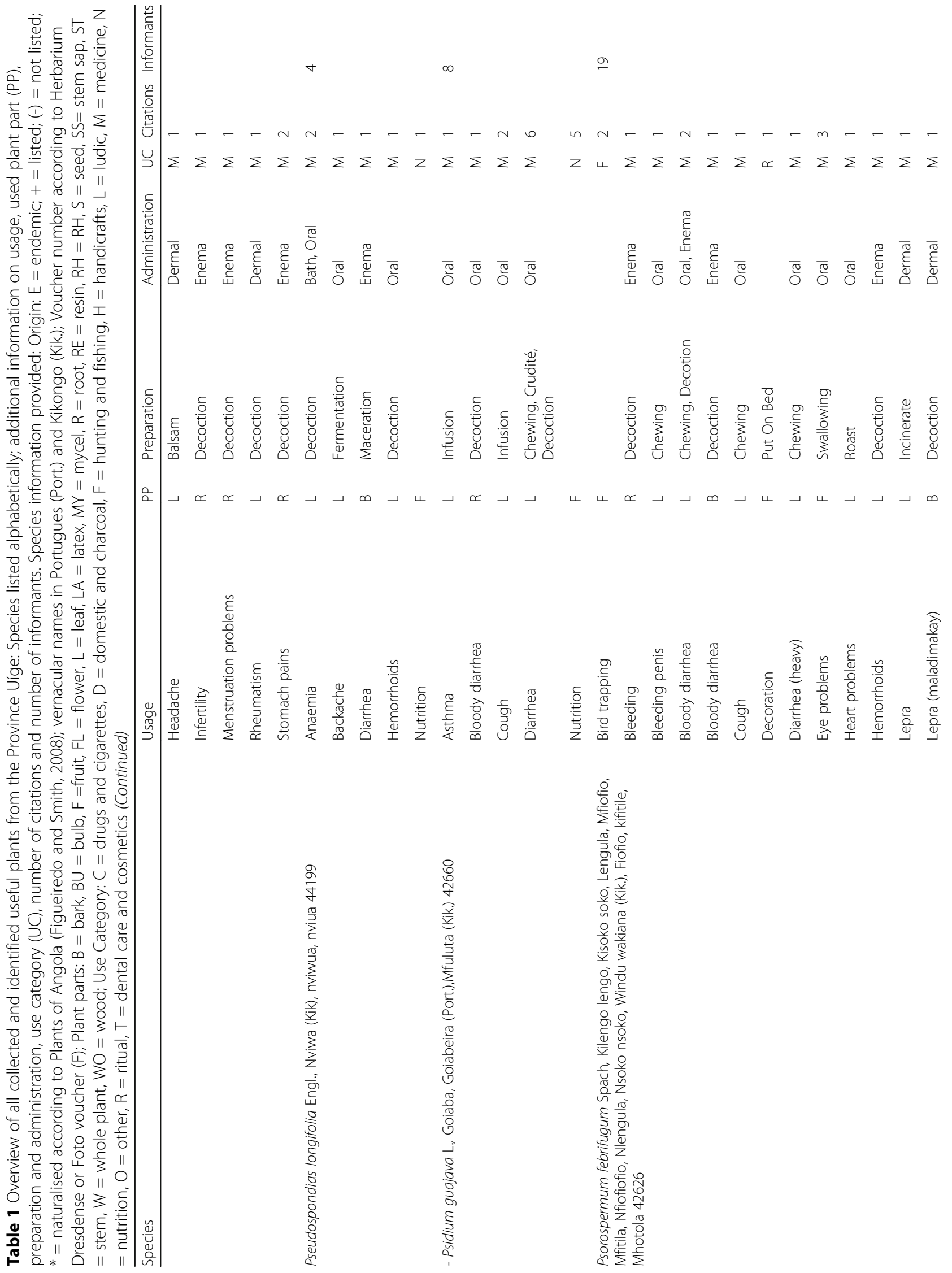




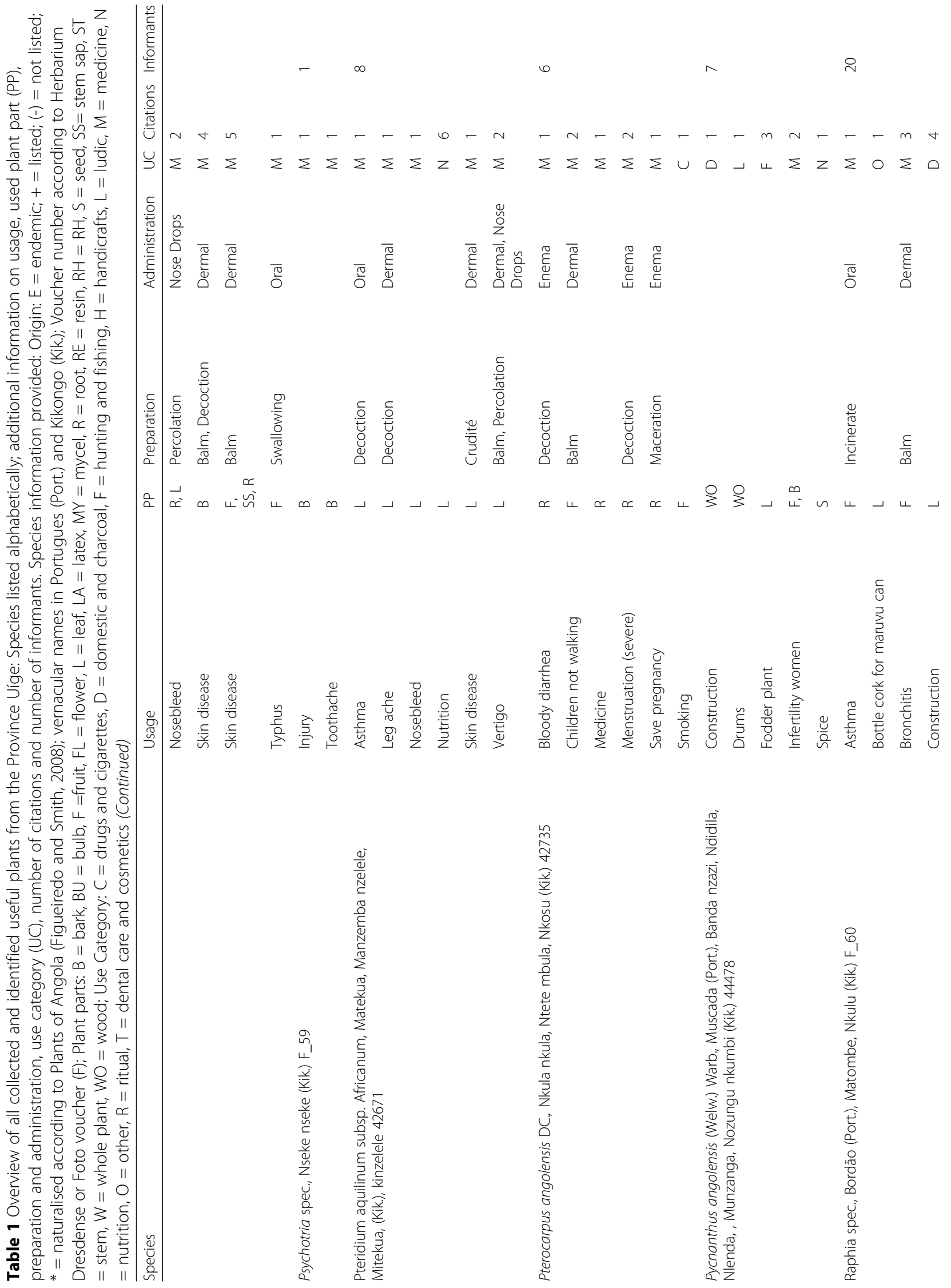




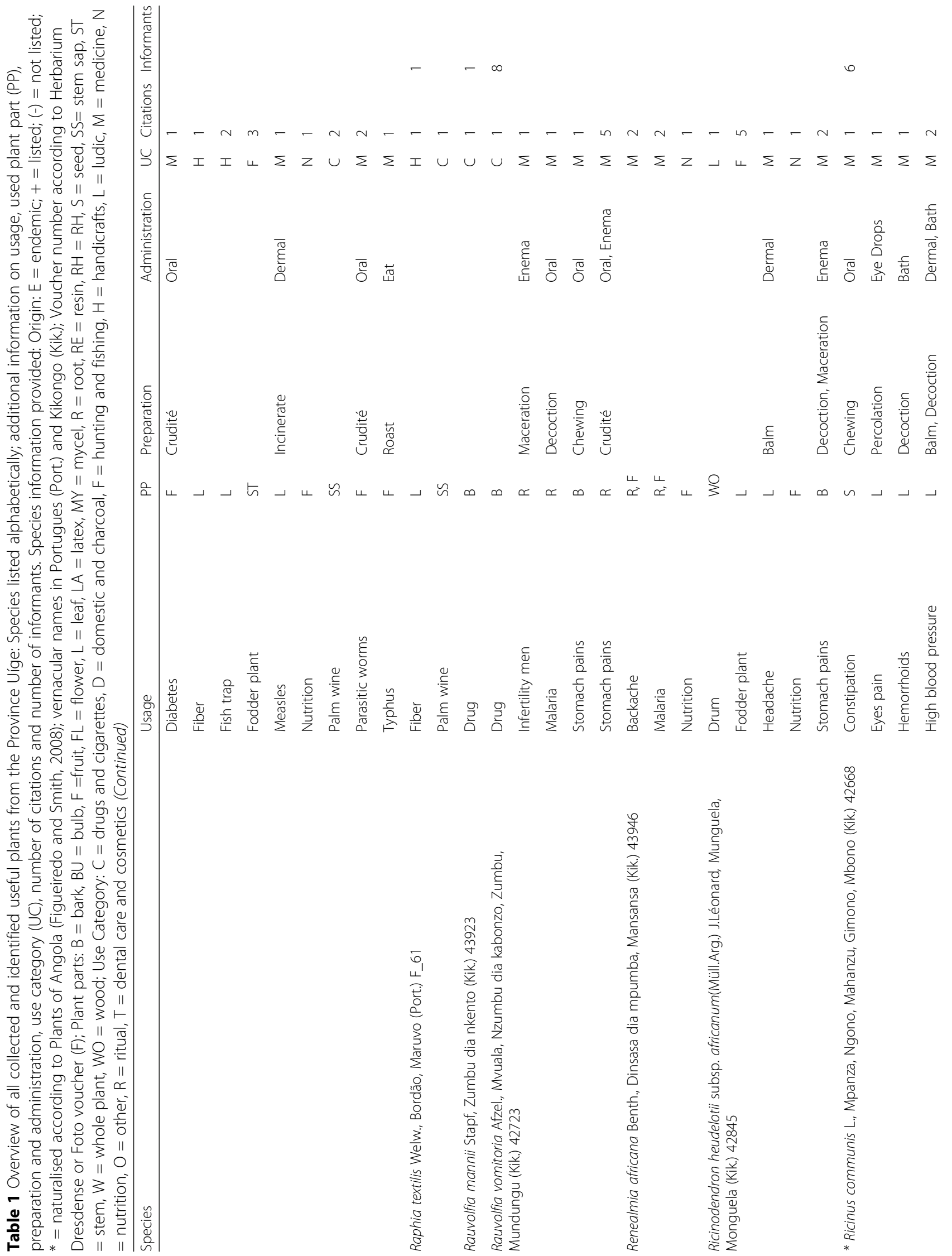




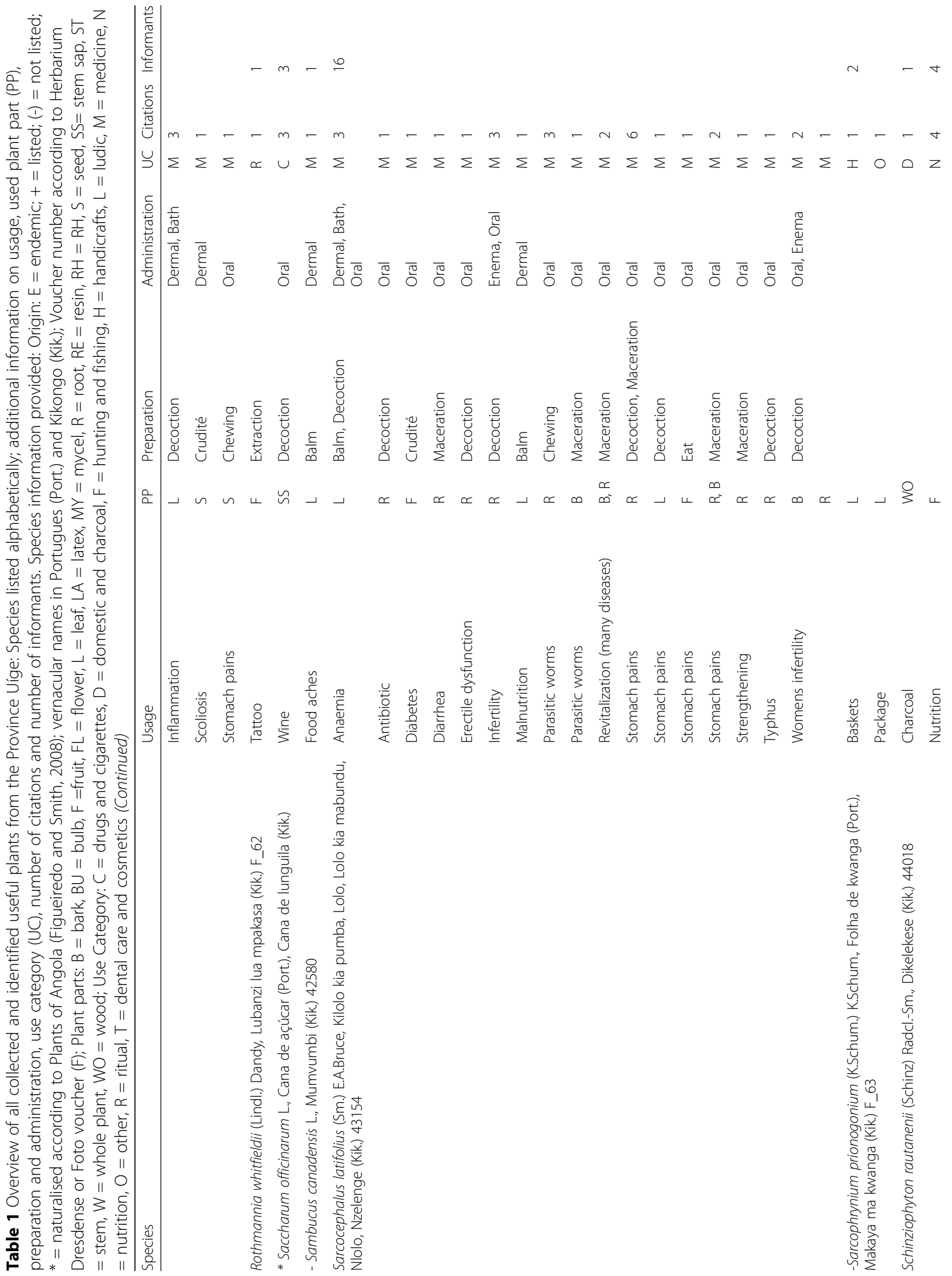




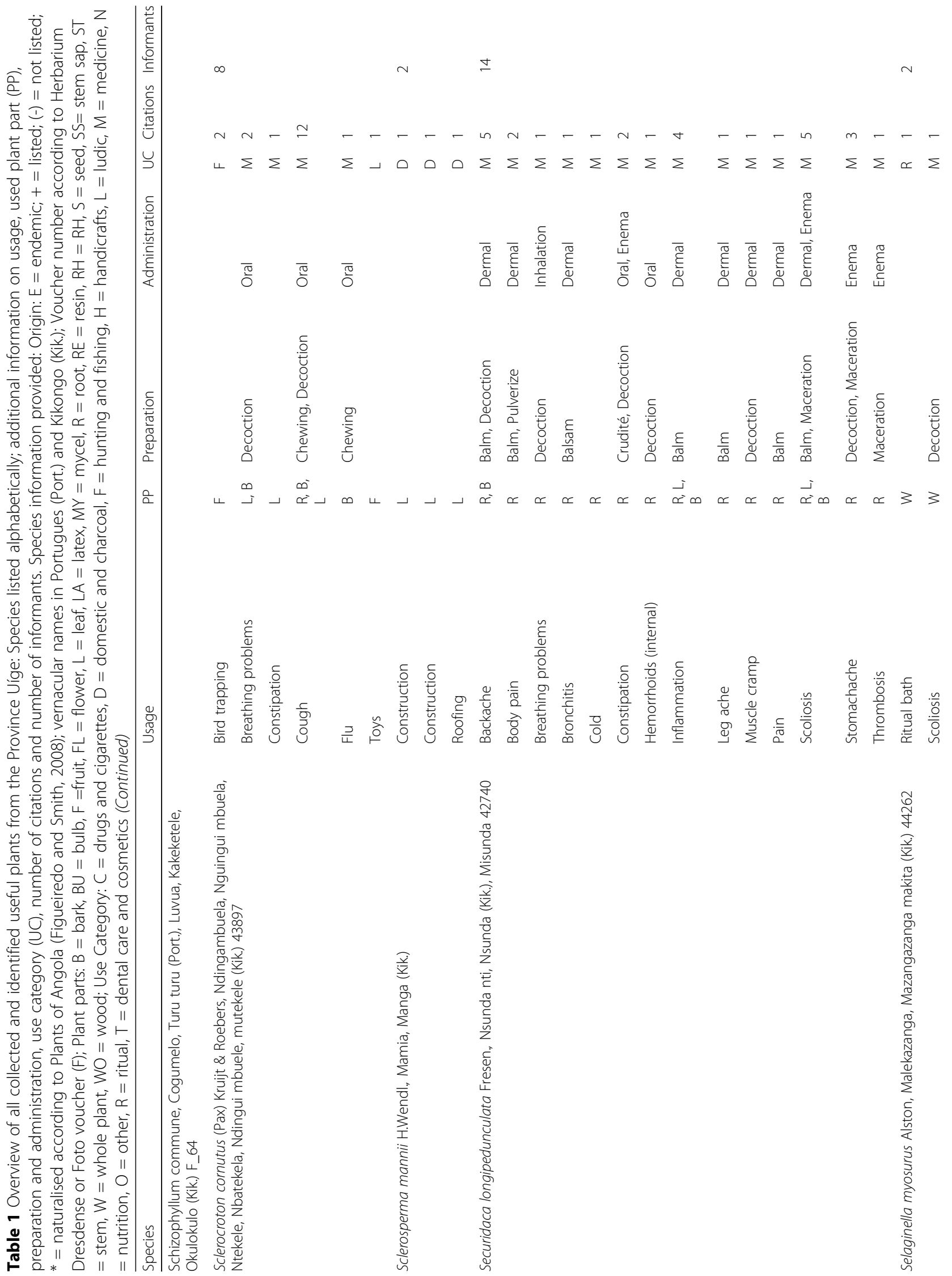




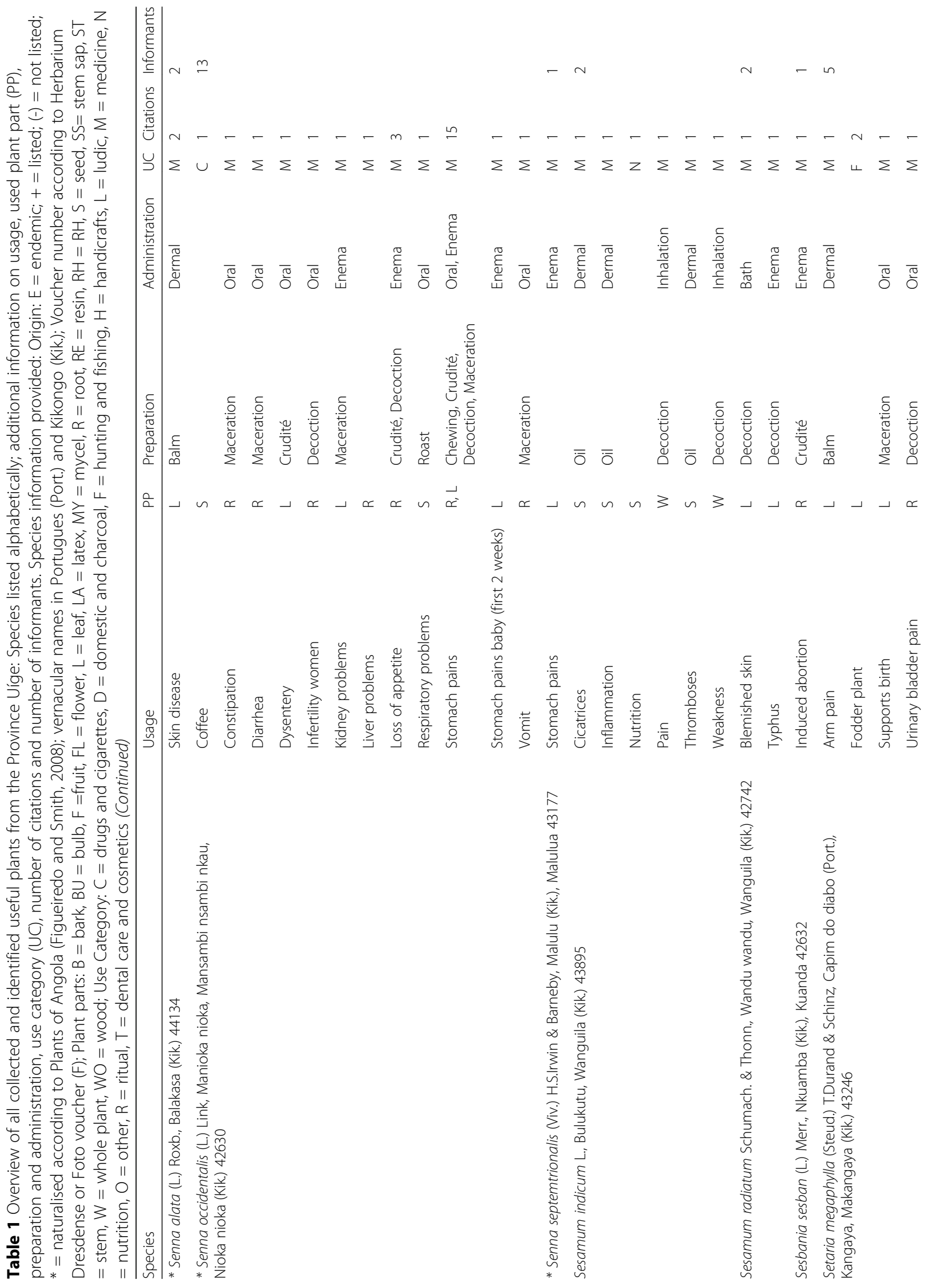




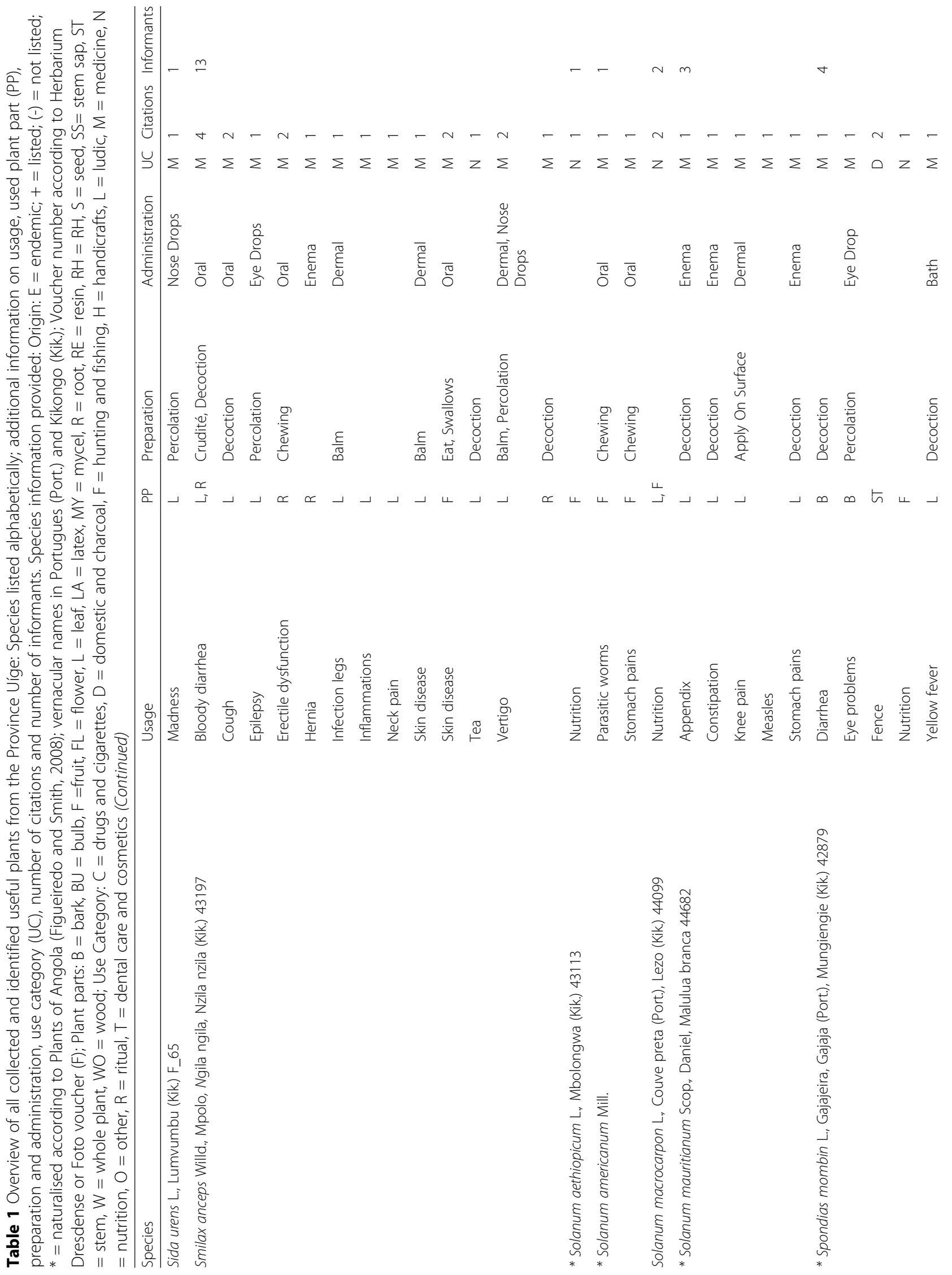




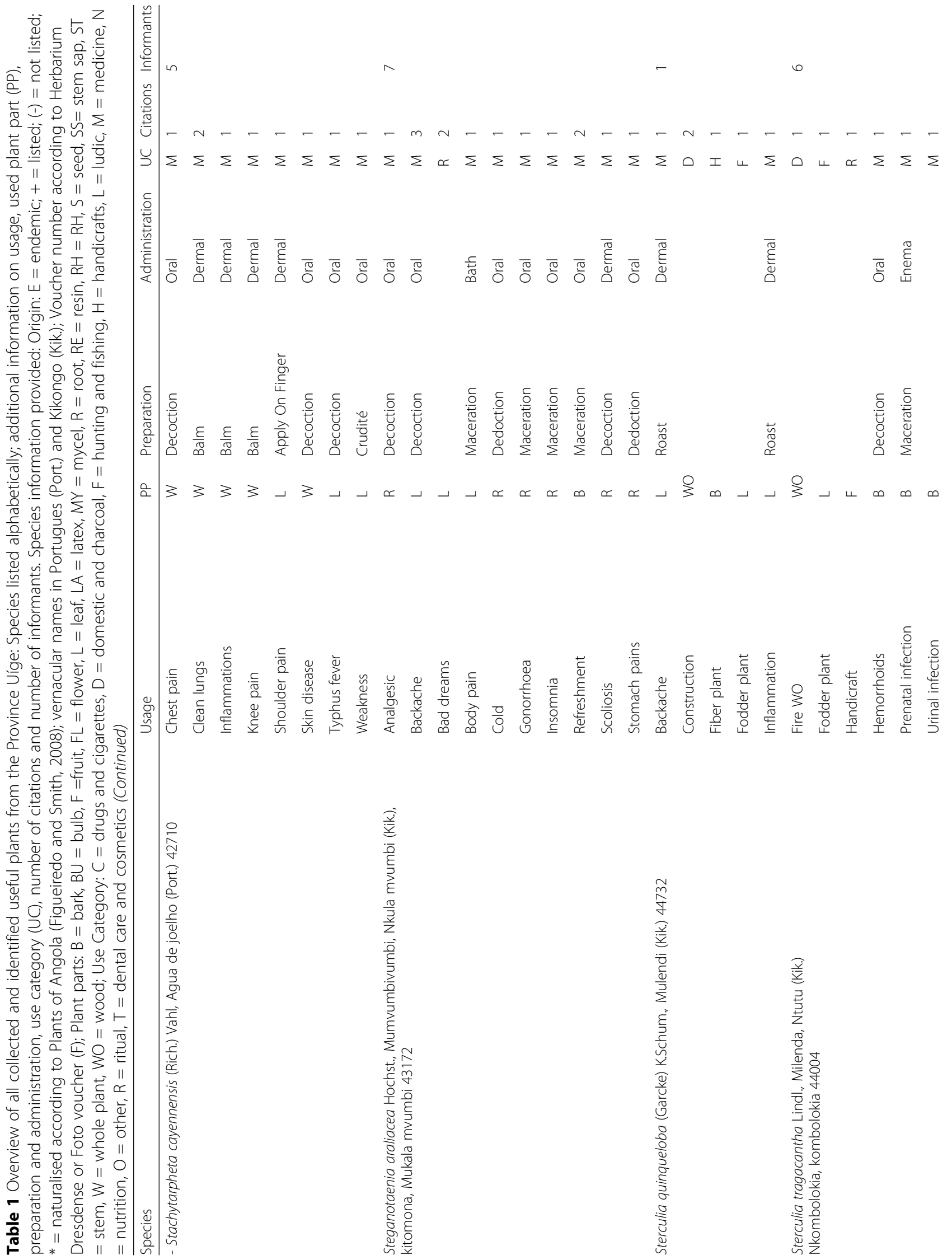




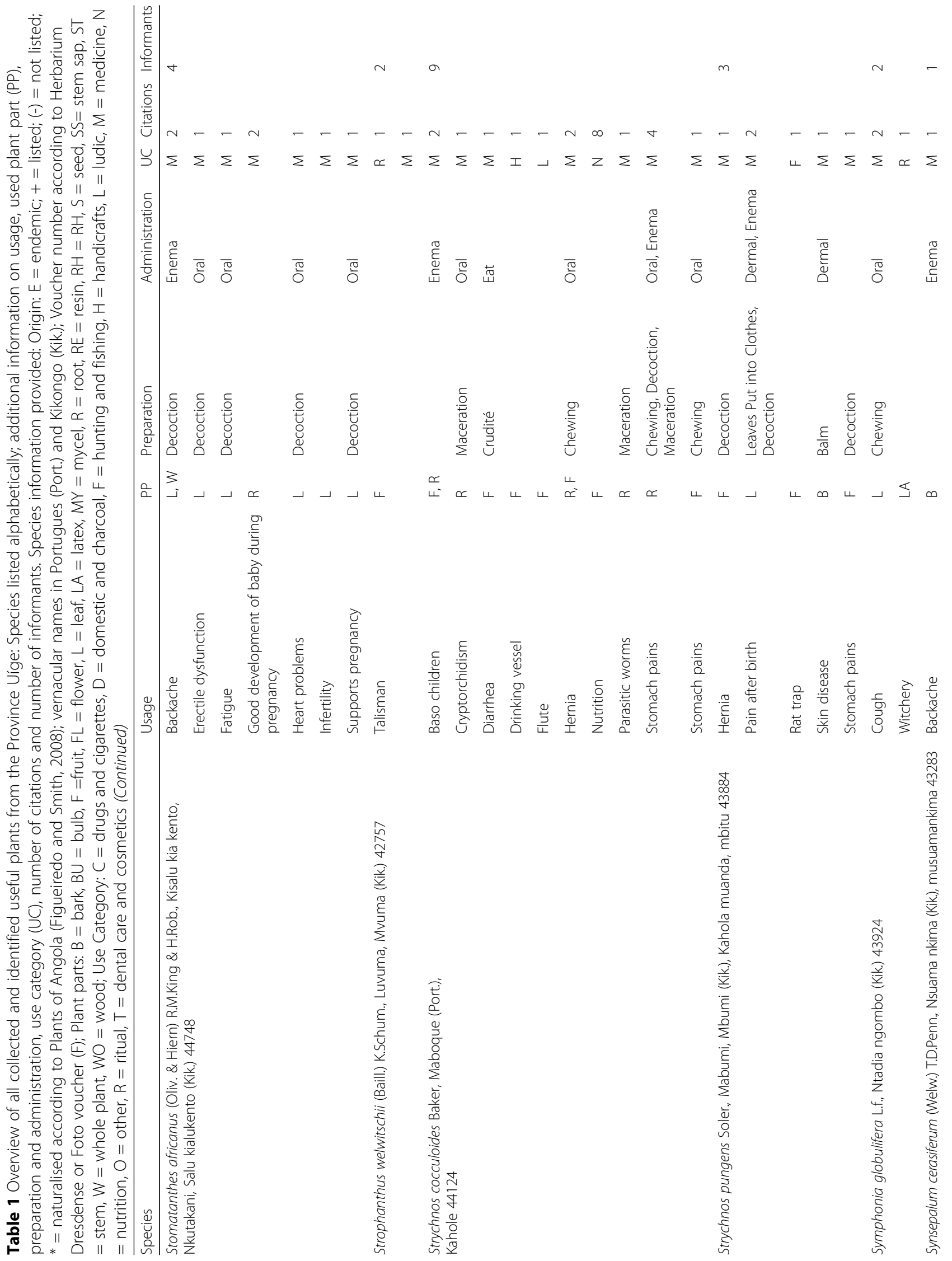


Lautenschläger et al. Journal of Ethnobiology and Ethnomedicine (2018) 14:51

Page 57 of 73

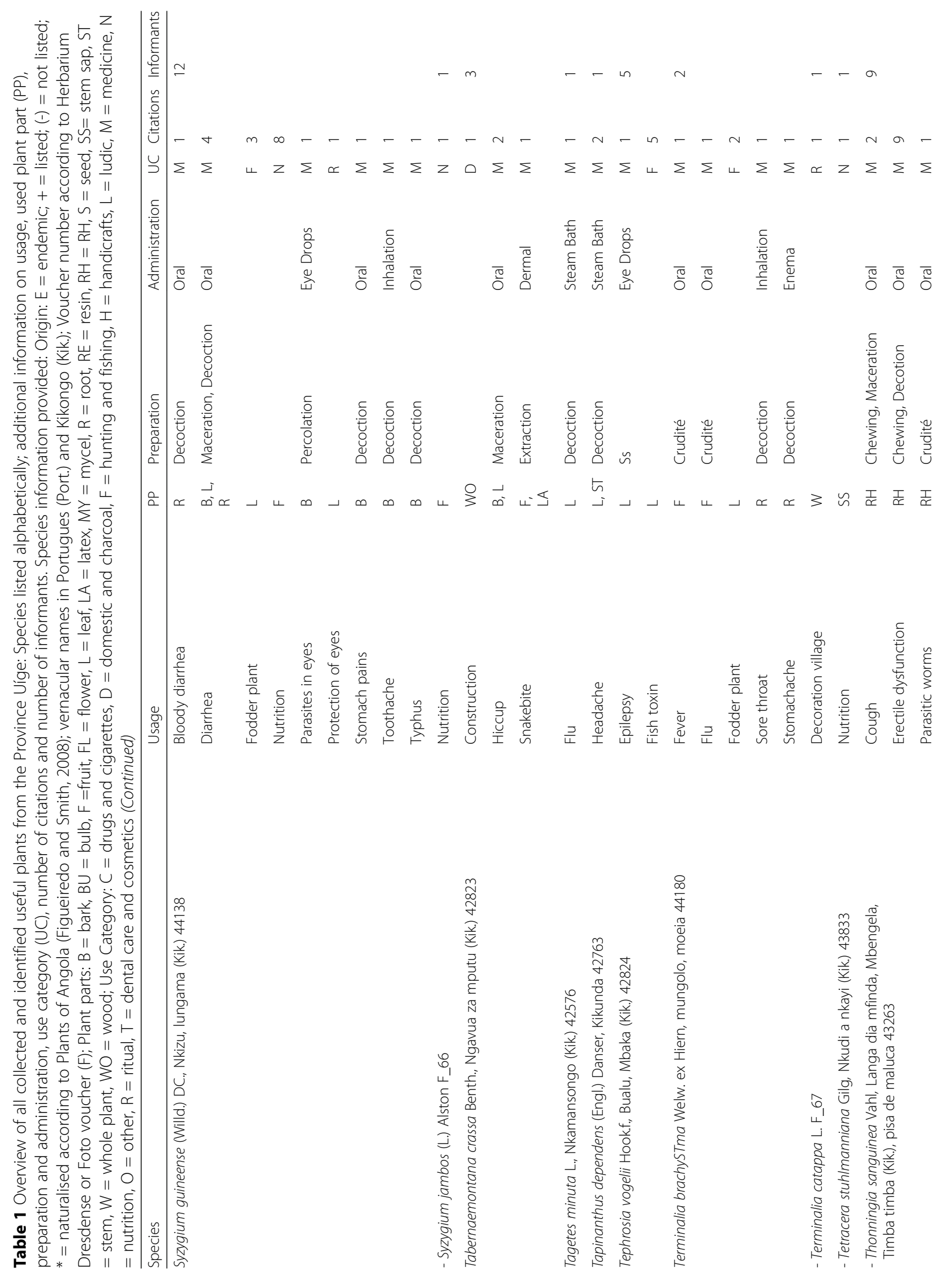


Lautenschläger et al. Journal of Ethnobiology and Ethnomedicine (2018) 14:51

Page 58 of 73

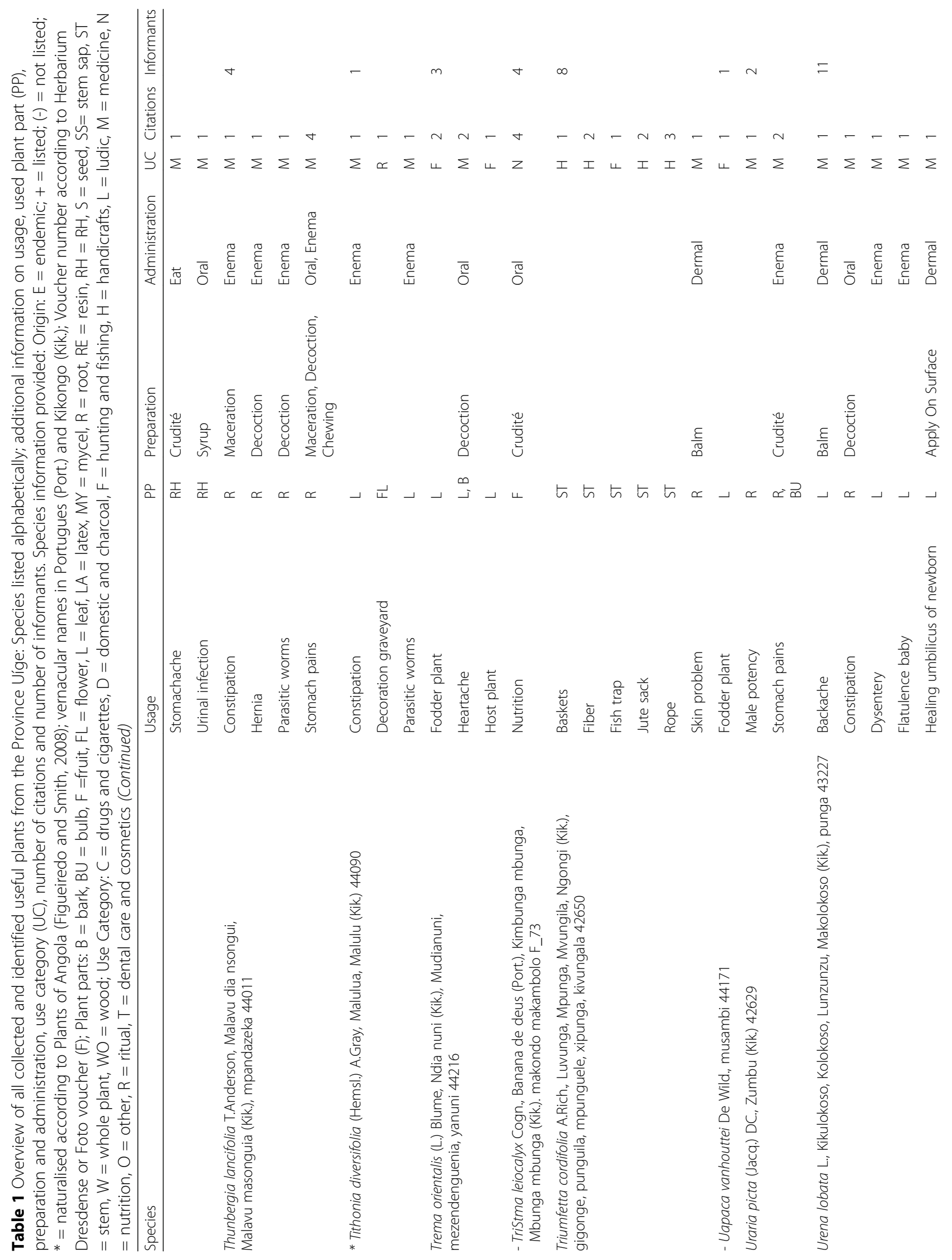




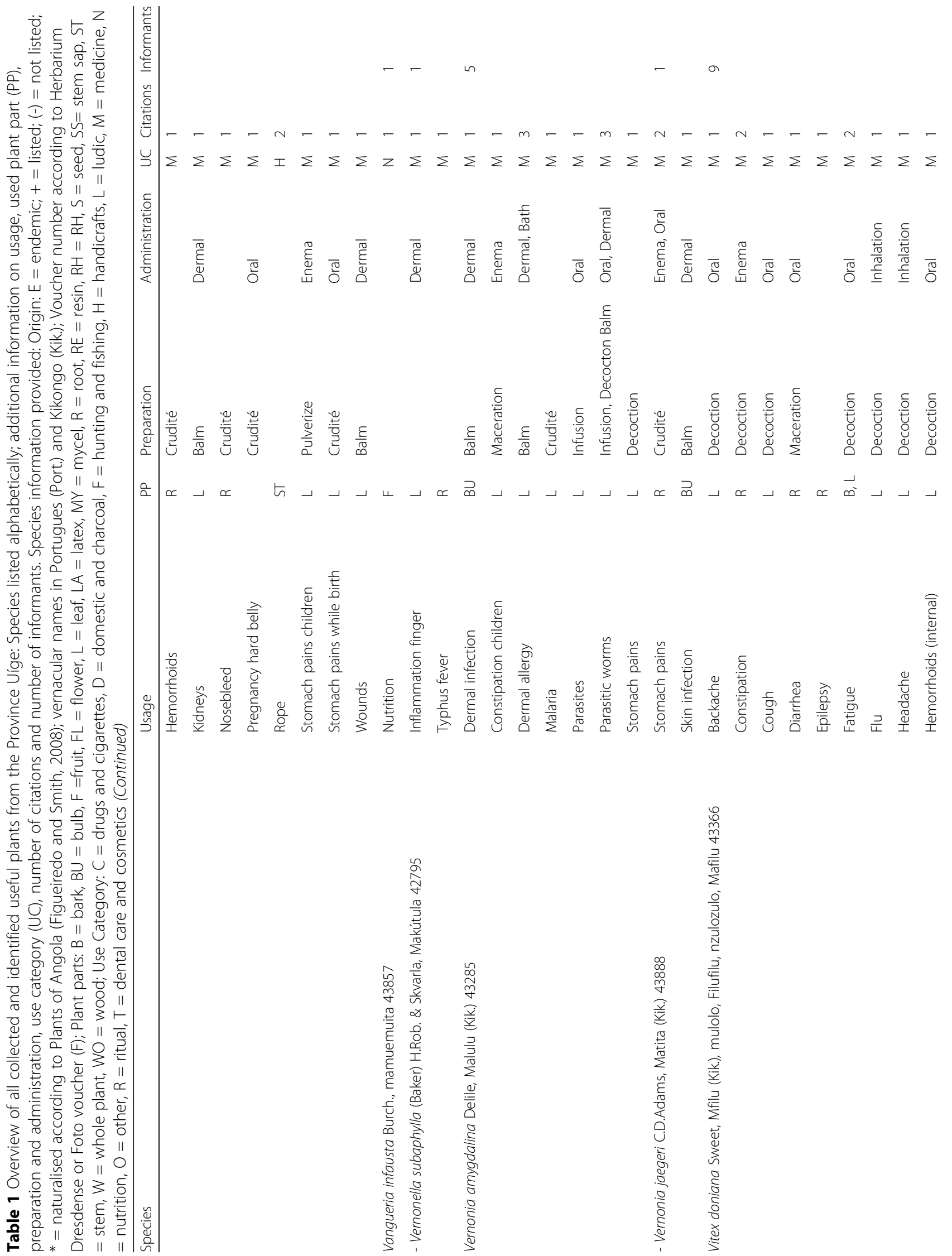




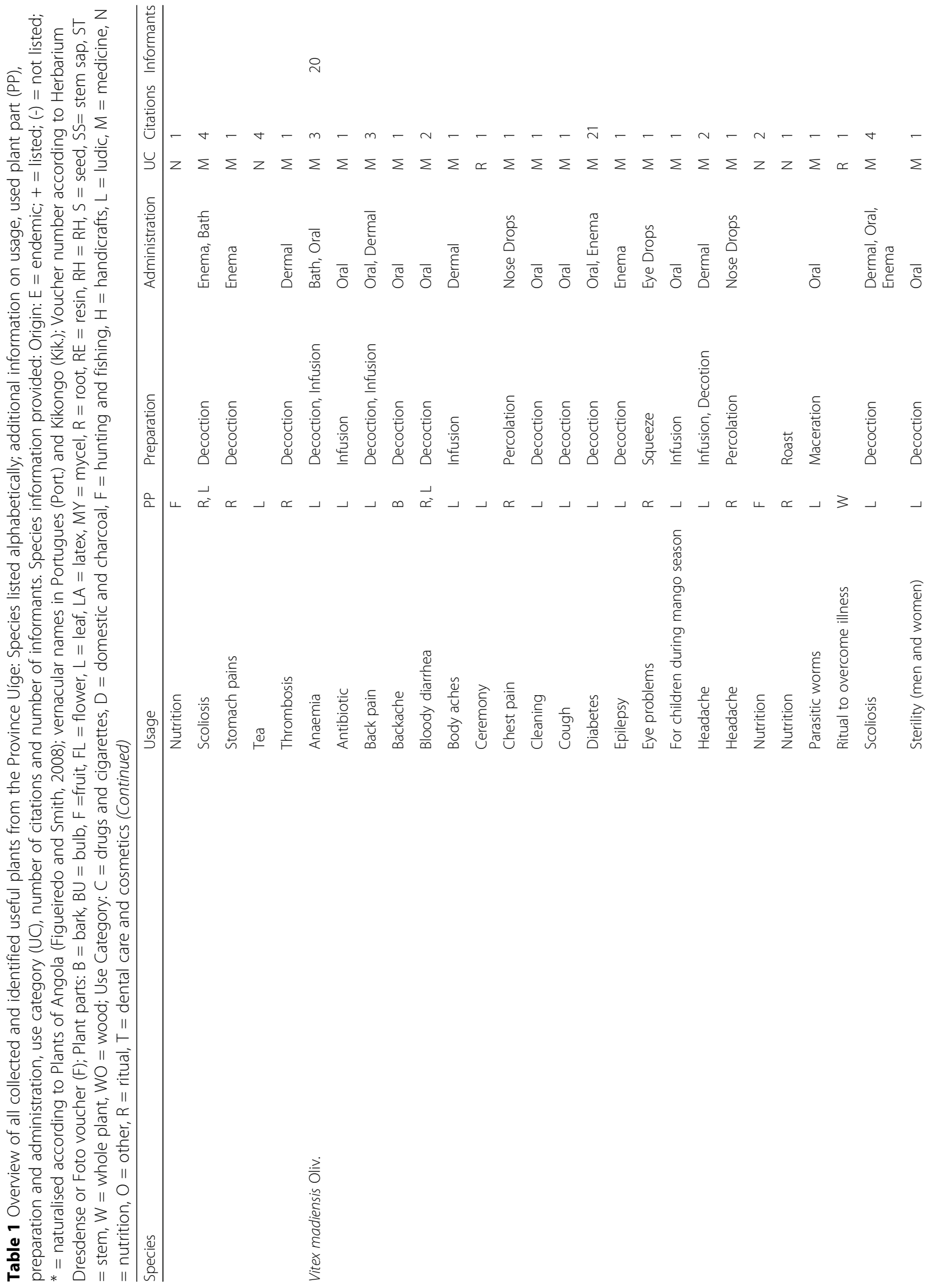




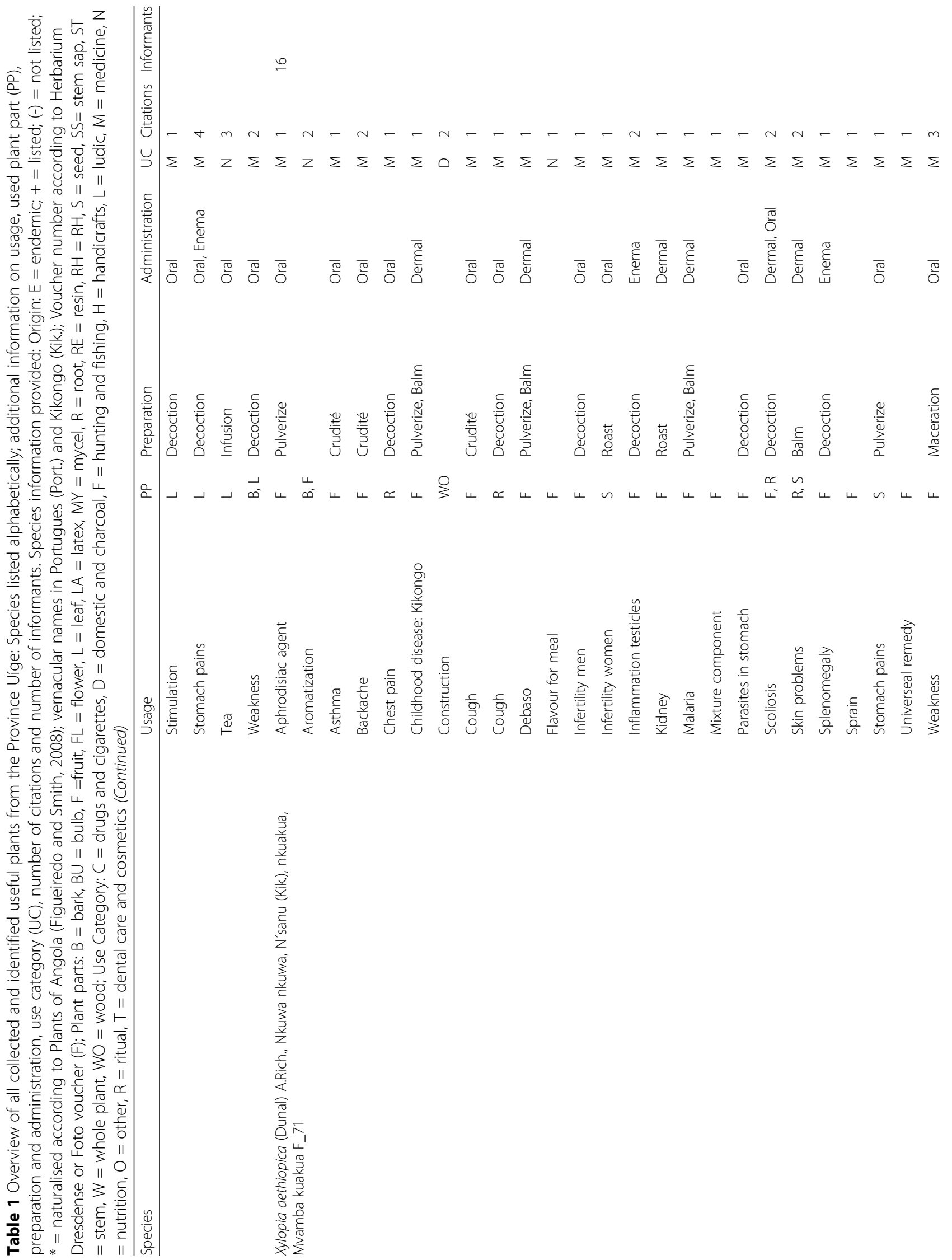




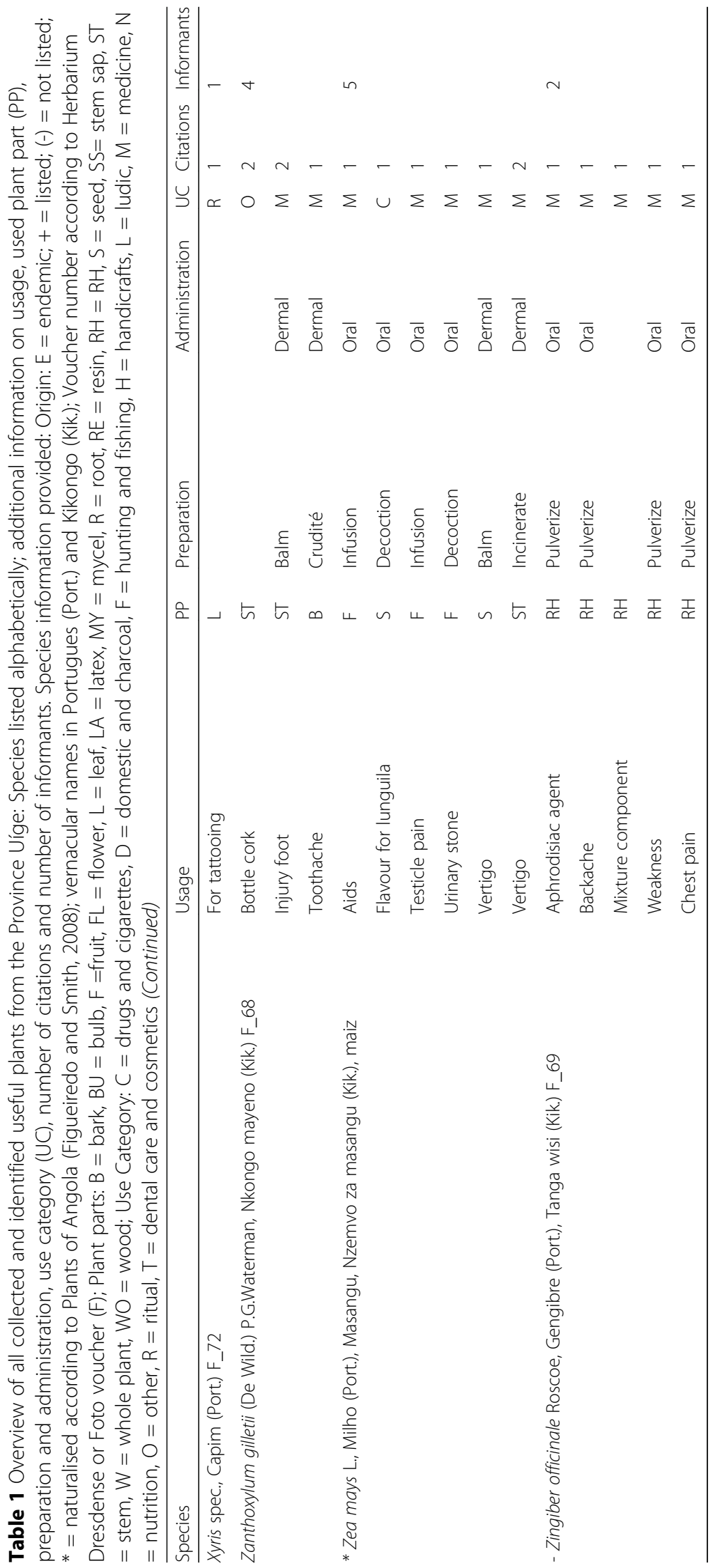


illustrate that healers use the same species for the treatment of the same illness.

$$
\mathrm{RFC}_{\mathrm{s}}=\frac{\mathrm{FC}_{\mathrm{s}}}{N}=\frac{\sum_{i=i_{1}}^{i_{N}} U R_{i}}{N}
$$

Formula 1: Calculation of the Relative Frequency of Citations (RFC): $\mathrm{s}=$ species, $\mathrm{FC}=$ Frequency of Citation by one informant; $N=$ total number of informants [54].

$$
\mathrm{CI}_{s}=\sum_{u=u_{1}}^{u_{\mathrm{NC}}} \sum_{i=i_{1}}^{i_{\mathrm{NI}}} \frac{\mathrm{UR}_{u i}}{N I}
$$

Formula 2: Calculation of the Cultural Importance Index $(\mathrm{CI}): \mathrm{s}=$ species, $\mathrm{u}=$ use categories; $N=$ total number of informants, $i=$ informants, $\mathrm{NC}=$ the number of use categories, $\mathrm{UR}_{\mathrm{ui}}=$ the use report of informant $\mathrm{I}$ in use [51].

$$
F_{i c}=\frac{n_{\mathrm{ur}}-n_{t}}{n_{\mathrm{ur}}-1}
$$

Formula 3: Calculation of the Informant Consensus Factor $\left(\mathrm{F}_{\mathrm{ic}}\right): n_{\mathrm{ur}}=$ number of use-reports in each use category; $n_{\mathrm{t}}=$ number of taxa used [56].

Literature available on medicinal applications of the listed plant species were used for comparison: Neuwinger [57], Iwu [58] and Latham and Konda ku Mbuta [11] of which the latter two reported data in the adjacent Democratic Republic of Congo [11, 57, 58]. In the following the term citation is used in the same way as use-report.

\section{Results and discussion}

\section{General findings on vegetation of used plants}

The heterogeneity of Uíge's landscapes and vegetation formations is mirrored by a high variability of data. Nevertheless, several tendencies can be postulated. Our study presents 2390 use-reports (Table 1). Three hundred fifty-eight species representing 96 plant families were identified, 17 of them only to genus level. Of these used plant species, $35 \%$ were trees, $26 \%$ perennial herbs, $16 \%$ shrubs, $12 \%$ climbers, $10 \%$ annuals and less than $1 \%$ parasites. In contrast to a study in southern Angola [6] and one in Namibia [59], woody plants are not used more frequently in our study area compared to herbs since herbaceous plants are found all year around due to the humid forest habitats, and because the much shorter dry season results in a higher availability of plants from savannah areas [6, 24]. Apparently, men (13\%) use more climbers than women (8\%) certainly due to the fact that climbers are a characteristic element of forest and transition zone where men are going to hunt regularly. However the difference is not significant (chi-square test, $P=0.108, X^{2}=2.578$ ). The use patterns of the other growth forms do not differ between genders in contrast to, e.g. in Eastern Tanzania, where women are more responsible for collecting herbaceous plants while men work with arborescent species [60].

Concurrently, $27 \%$ are plants growing in different savannah types, $24 \%$ in forests, and $21 \%$ in the transition zone connecting these two ecosystems. Furthermore, $20 \%$ of the used plants are cultivated, $7 \%$ were collected in disturbed areas and 1\% are water plants. Comparing habitat and growth form data, some features become apparent. Forty-five percent of the forest species are trees, $21 \%$ climbers. This proportion is shifting towards the transition zone where $40 \%$ are trees and $31 \%$ climbers. These often anthropogenically induced forest edges are characterized by a moist climate with a simultaneous high solar radiation imitating natural gaps caused by treefall. As tropical rainforest disturbance increases, relative abundance of climbers increases, as well $[61,62]$. In contrast, from the collected plant species of the studied savannah formations, $42 \%$ are trees and $32 \%$ perennial herbs [24]. Fifty percent of species collected in disturbed areas are annual herbs, which confirms the fact that annuals are typical for disturbed areas [63]. While just three out of 358 mentioned species are endemic to Angola, 71 species are naturalized that is equivalent to one fifth, $73 \%$ of which are still cultivated. In total, $15 \%$ of all citations refer to these species. This high number is not surprising. Different studies document the integration of introduced plants into the ethnobotanical repertoires of people $[7,64,65]$. In a study in Brazil, Santos et al. [66] even detected that invasive species overall were considered useful more often than non-invasive species. A closer look reveals that the naturalized species do not fill a gap described in Alencar et al. or Medeiros et al. $[67,68]$. They make up a small part in all medicinal categories with an average of $14 \%$, with just one exception in the category "fevers, malaria" where they represent $36 \%$. Out of the 53 citations for this disease category, 15 citations are based only on Chromolaena odorata (L.) R.M.King \& H.Rob. (8) and Dysphania ambrosioides (L.) Mosyakin \& Clemants (7). Although a wide range of species exist to treat stomachache, the most frequently used species is Senna occidentalis (L.) Link, introduced from tropical America, and used for various applications worldwide [69].

Angola's turbulent history as a Portuguese colony and the resulting cultural influences from other Portuguese colonies such as Brazil led to an interchange of plant use and knowledge as for Nicotiana tabacum L., which arrived in Africa in the 1600s or Arachis hypogaea L., which was incorporated at the same time into African ethnomedical systems [70]. In particular, certain arable crops from the New World were introduced in Angola, especially from the Solanaceae and Euphorbiaceae. 
Actual international listings and reports on neophytes and invasive species are still very incomplete for Angola $[71,72]$. According to the list of invasive species in Eastern Africa [73], 24 species of our study are detected to have invasive potential. Due to our observations in northern Angola, six plant species display an invasive behaviour: Chromolaena odorata (L.) R.M.King \& H.Rob., Inga edulis Mart., Lantana camara L., Senna occidentalis (L.) Link, Solanum mauritianum Scop., and Tithonia diversifolia (Hemsl.) A.Gray. The species of most invasive power Chromolaena odorata forms dense thickets in savannah and forest gaps, disrupting forest successions.

Local people are aware that this plant is not native to their region. Different myths surround its arrival suggesting that Chromolaena odorata was introduced rather recently [32, 72]. Nevertheless, in terms of its traditional use in our study, it is in 6th position regarding its RFC-value (Table 2).

With regard to the species number, the predominant used plant families are Fabaceae (11.7\%), Asteraceae (6.1\%) and Rubiaceae (5.6\%), followed by Apocynaceae, Malvaceae and Euphorbiaceae (4.2\%). The distribution of plant families is difficult to discuss without referring to the occurring vegetation units. Our results therefore confirm the mosaic like heterogeneity of the studied area, influenced by Guineo-Congolian rain forests, Zambesian dry evergreen forests, Miombo woodlands and secondary (wooded) grasslands [24]. This shows a respective preference: species from Fabaceae and Asteraceae have a high percentage of used savannah plants (> $50 \%)$ while the percentage of forest plants increases within the other families, especially in Rubiaceae (26\%).
The quotient of citations and species number within one plant family $(\mathrm{C} / \mathrm{S})$ emphasizes the importance of citations within one plant family, including the fact that big families like Fabaceae or Asteraceae inherently show high citation numbers. As illustrated in Fig. 2, some plant families were mentioned with just a few species but high citation rate (high $\mathrm{C} / \mathrm{S}$ ). For example in Annonaceae, 120 citations for 5 species lead to a $\mathrm{C} / \mathrm{S}$ of 24 . While the families Annonaceae and Asteraceae exhibit an equally high number of citations, the number of species is considerably higher in Asteraceae. The proportion for one species therefore is much higher in Annonaceae than in Asteraceae. By contrast, in Solanaceae, 34 citations for 11 species lead to a $\mathrm{C} / \mathrm{S}$ of 3.1.

\section{Ethnobotanical results}

Willingness of visited people to collaborate was very high. One hundred sixty-two informants were interviewed in 62 groups. Two thirds were older than 40 years. Some healers specialized on one or two diseases only while others demonstrated their broad knowledge to heal a large variety of diseases (Additional file 1).

Seventy-six percent of the citations collected in our study refer to medicinal uses, $10 \%$ to nutritional use and $4 \%$ to its use as fodder plant. The remaining $10 \%$ are divided into the other 7 use categories. Although the unequal split of citations within the 10 use categories suggests a low use of plants in some of them, plenty of species are used for several purposes and daily needs. Thus, 41 species are used for domestic applications, 33 species for rituals, 29 species as drugs or cigarettes, 21 species for handicrafts and 9 for ludic ambits. Compared to other studies (e.g. Vodouhê, [74]), the percentage of medicinal uses is very high, although Göhre et al. [7]

Table 2 List of the 11 species with the highest Relative Frequency Citation (RFC) including habitat, used plant parts (PP), use categories (UC), number of citations (NC), and Cultural Importance Index (Cl). Habitat (Hab.): C cultivated, $F$ forest, $S$ savannah. Plant Parts: B bark, $F$ fruit, $L$ leaf, $R$ root, $S$ seed, SS stem sap, ST stem, $W$ whole plant, Wo wood. Use category: $C$ drugs and cigarettes, D domestic and charcoal, $F$ Hunting, fishing and animal feed, $H$ handicrafts, $L$ ludic, childrens' toys, $M$ medicinal use, $N$ nutrition, spices and herbal teas, $R$ rituals, $T$ dental care and cosmetics, $O$ others; ${ }^{*}$ neophyte

\begin{tabular}{|c|c|c|c|c|c|c|}
\hline Species & Hab. & PP & UC & NC & RFC & $\mathrm{Cl}$ \\
\hline Annona stenophylla subsp. cuneata & $S$ & $R, L, F$ & $\mathrm{M}, \mathrm{N}$ & 50 & 0.371 & 0.435 \\
\hline Hymenocardia acida & $S$ & $B, L, R, S$ & M & 40 & 0.355 & 0.355 \\
\hline Vitex madiensis & $\mathrm{S}$ & $B, L, R, F, W$ & $M, N, R$ & 43 & 0.323 & 0.468 \\
\hline Psorospermum febrifugum & S & $B, L, R, F, S S$ & $F, M, R$ & 29 & 0.306 & 0.371 \\
\hline Raphia matombe & $\mathrm{F}$ & $F, L, S S, S T$ & $C, D, F, H, M, N, O$ & 24 & 0.306 & 0.371 \\
\hline Chromolaena odorata* & $S$ & $L, W$ & $\mathrm{M}, \mathrm{O}$ & 26 & 0.274 & 0.290 \\
\hline Elaeis guineensis & C & $B, F, F L, L, R, S S, S$ & $C, F, H, M, N, O, R$ & 35 & 0.274 & 0.387 \\
\hline Aframomum alboviolaceum & $S$ & $F, L, R, S T$ & $\mathrm{M}, \mathrm{N}$ & 34 & 0.258 & 0.339 \\
\hline Sarcocephalus latifolius & $S$ & $B, F, L, R$ & M & 32 & 0.258 & 0.242 \\
\hline Smilax anceps & $S$ & $F, L, R$ & $M, N$ & 20 & 0.258 & 0.226 \\
\hline Xylopia aethiopica & $\mathrm{F}$ & $B, F, R, S$, Wo & $D, M, N$ & 33 & 0.258 & 0.306 \\
\hline
\end{tabular}




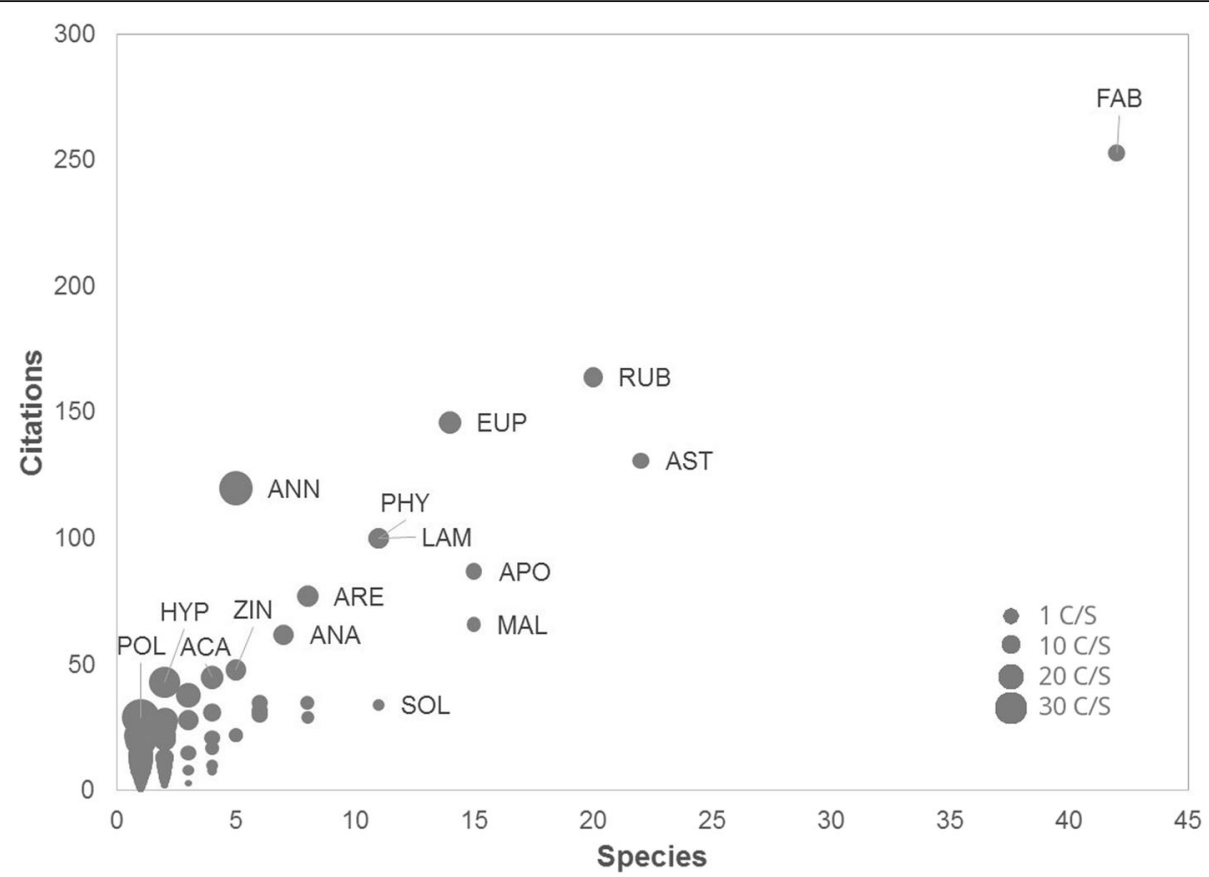

Fig. 2 Plant family distribution correlating species number with the number of citations including data about its C/S-Quotient depicted by the size of the circles. Abbreviations of families: ANN Annonaceae, ACA Acanthaceae, ANA Anacardiaceae, APO Apocynaceae, ARE Arecaceae, AST Asteraceae, EUP Euphorbiaceae, HYP Hypericaceae, LAM Lamiaceae, MAL Malvaceae, PHY Phyllanthaceae, POL Polygalaceae, RUB Rubiaceae, SOL Solanaceae, ZIN Zingiberaceae

detected quite similar use category distributions. One reason might be that our study design required at least one person with knowledge of traditional medicine to accompany the interview. On the other side, this split is an indication of the crucial role of plants in rural health care.

In general, the predominantly used part is the leaf $(37 \%$, 890 citations, 220 species), followed by the different stem tissues wood, bark, bast fibres, and resins (17\%, 407 citations, 110 species), underground organs like roots, tubers and rhizomes (15\%, 367 citations, 140 species) as well as fruits and seeds with 15\% (354 citations, 114 species). In some cases, the whole plant (56 citations, 27 species) or flowers (16 citations, 12 species) were used. Regarding only the medicinal use category, the proportion of the citations describing the use of leaves remains almost unchanged with 39\% (689 citations, 178 species) while the proportion of the use of underground organs increases by more than the double to $32 \%$ (582 citations, 137 species). This detected plant part percentage is consistent with the one observed by Urso et al. [6], Giday et al. [75], or Cheikhyoussef and Embashu, [76]. As already mentioned and discussed in Urso et al. [6], the intensive use of underground organs in medical applications may be due to the fact that underground organs need effective defence strategies based on a high content of secondary metabolites [6, 77]. By contrast, the studies of Upadhyay and Kumar [78] and Panghal et al. [79] confirm leaves as the most frequently used plant part in remedies [78, 79]. In this context, strain and increasing mortality in species of which primarily bark and roots or bulbs are collected for remedies, are discussed [80-83]. No awareness of interviewed people in Uíge province for this emerging problem was detected during our study.

As expected, in the category "nutrition", the main plant parts used are fruits (57\%), leaves (31\%), and seeds (5\%) which is in concordance with literature $[6,76]$. Fruits are consumed fresh, except the fruits of Adansonia digitata L., Piper guineense Schumach. \& Thonn. and Xylopia aethiopica (Dunal) A.Rich. which can also be dried. Tubers, although an important source of starch, were seldom mentioned. This may be because during field trips these tubers are not abundant but normally cultivated. For fodder purposes, mainly, leaves are used (75\%); fruits and stem tissues only play a subordinate role.

Stems and timber, respectively, are the main plant parts used domestically (67\%). Except the significantly more frequent utilization of fruits and seeds by women (chi-square test, $P=7 \times 10^{-5}, X^{2}=15.8$ ), no other gender-specific difference was detected. This result could be caused by the daily behaviour and responsibilities women have; those inter alia walk to and work in the field, carry and take care of the children while collecting edible fruits along the wayside. For the Ibo women in Nigeria for instance, their ownership of fruit trees was described [84]. 


\section{Ethnobotanical indices of used plants}

RFC and CI of all mentioned species were calculated to evaluate the importance of the species use. Here, $67 \%$ of the species have a RFC below $0.05,14 \%$ between 0.05 and 0.1 , and $20 \%$ more than 0.1 . The values range from 0.37 to 0.02 . The species with the highest RFC also show a high variety of its used plant parts and use categories (Table 2). The calculated CI covers values from 0.47 to 0.02 with an average value of 0.07 while Göhre et al. [7] calculated an average value of 0.09 in savannah regions near Uíge city.

Eight of the 11 species listed in Table 2 are typical savannah species demonstrating the importance of this vegetation in traditional plant usage [7]. The most important species is Annona stenophylla subsp. cuneata (Oliv.) N. Robson, a subshrub, which, due to its woody rhizome, is able to regrow after periodical fires. Fruits are edible, frequent and therefore known by everyone. Its medicinal use is broad but with focus on gastrointestinal disorders. This application was mentioned for the related A. stenophylla and A. stenophylla subsp. nana [57]. Hymenocardia acida Tul. as well as Psorospermum febrifugum Spach are frequent small savannah trees often used for treating bloody diarrhoea, bleeding or anaemia due to its red root bark producing a reddish coloured decoction and therefore related to blood, according to the tradition of local people. We noticed a comparable relationship between the bark of Erythrina abyssinica DC., which produces a yellow decoction and is used to treat yellow fever, and the use of pulverized thorns of the trunk of Zanthoxylum gilletii (De Wild.) P.G.Waterman to treat injuries to the feet. Hence, for some plants, appearance is related to functionality, comparable to the doctrine of signatures developed by Paracelsus in the sixteenth century $[85,86]$. The shrub Vitex madiensis Oliv. produces edible fruits and has a wide variety of healing properties. Another frequent tree is Sarcocephalus latifolius (Sm.) E.A.Bruce whose roots are often sold at local markets as a tonic. Aframomum alboviolaceum (Ridl.) K.Schum. is a common perennial that produces edible fruits sold at local markets during the late rainy season. Smilax anceps Willd. is the only climbing plant in this list, widespread in African savannahs and therefore used diversely [57].

Secondly, three species (Elaeis guineensis Jacq., Raphia matombe De Wild., Xylopia aethiopica (Dunal) A.Rich) are an important part of remedy mixtures and thus quite well known in the literature [57]. Several liposoluble substances can be dissolved in the oil of Elaeis guineensis fruits, which is therefore used for skin diseases [57, 58]. At the same time, palm fruits present a food for better nutrition and health due to its components such as palmitic-oleic rich semi solid fat as well as vitamin E, carotenoids and phytosterols [87]. Xylopia aethiopica is most commonly used as an addition to remedy mixtures of pulverized seeds due to its diverse constituents $[58,88]$. In contrast, the other palm species Raphia matombe is one of the most important species in Bakongo culture inter alia because of its common traditional utilization to produce palm wine [89]. In addition, alcohol also serves as solvent for active ingredients [90-92]. Some plants traditionally are macerated in alcoholic beverages and used in medical applications, mainly as aphrodisiac or against pain [57]. However, parts of Raphia also serve as base for other applications such as the leaf rachis for domestic use, edible fruits or fibres for handicrafts [32].

Interestingly, the invasive species Chromolaena odorata, native to Central-America, is part of the list but also used worldwide for the same purpose or other applications [90, 91, 93-95]. Its biochemical and antimicrobial activities as well as anticancer properties are already well studied [96, 97].

\section{Ethnobotanical indices of medical plants}

If we consider only medical plants, the selected ethnobotanical indices attain values similar to those for the useful plants in general. Out of the 1813 use reports, $68 \%$ of the listed plant species exhibit a RFC below 0.05 (corresponding to 3 citations maximal, 13\% between 0.05 and 0.1 (4 to 6 citations), and $19 \%$ more than 0.1 (from 7 citations up). The values range from 0.34 to 0.02 . The species with the highest RFC in this use category are shown in Table 3. Eight of them are already mentioned in Table 3. The calculated CI values range from 0.44 to 0.02 with an average value of 0.08 .

Ten percent out of 1813 citations for medicinal uses refer to stomach ache (183 citations), $8 \%$ to respiratory diseases (140 citations), 7\% to pain and rheumatism (124 citations), $6 \%$ to diarrhoea (115 citations) and 6\% to headache and weakness (101 citations). According to Heinrich et al. [55], the informant's consensus can help to select plant species for further pharmaceutical analyses. The calculated Informant Consensus Factor $\left(\mathrm{F}_{\mathrm{IC}}\right)$ of the 41 secondary use categories ranged between 0 and 0.78 . The disease "measles" has the highest $\mathrm{F}_{\mathrm{IC}}(0.78)$, followed by the disease groups "diarrhoea" (0.61), "skeletal deformation" (0.6), "anaemia" (0.58) and "stomach ache" (0.58). For 14 out of the 41 defined disease categories, $\mathrm{F}_{\mathrm{IC}}$ was below 0.2 . Table 4 shows the plant species, which were cited at least five times for one disease, sorted by the Informant Consensus Factor $\left(\mathrm{F}_{\mathrm{IC}}\right)$ of each disease. Statistical analysis with Chi-square test of independence did not detect any significance in gender-specific treatment of the 41 disease categories, except in the treatment of scoliosis (chi-square test, $P=1 \times$ $\left.10^{-9}, \chi^{2}=37.1\right)$.

The importance of traditional medicinal plants is demonstrated by the high number of medical use-reports 
Table 3 List of 11 medical plant species with the highest Relative Frequency Citation (RFC) including habitat, used plant parts (PP), and Cultural Importance Index (CI). Habitat: C cultivated, F forest, S savannah. Plant parts: B bark, F fruit, L leaf, R root, S seed, SS stem sap, ST stem, W whole plant; *neophyte

\begin{tabular}{lllll}
\hline Species & Habitat & PP & RFC \\
\hline Hymenocardia acida & S & B, L, R, S & 0.3387 & 0.4355 \\
Vitex madiensis & S & B, L, R & 0.3226 & 0.4032 \\
Psorospermum febrifugum & S & B, F, L, R, SS & 0.3065 & 0.3226 \\
Annona stenophylla subsp. cuneata & S & L, R & 0.2903 & 0.4032 \\
Chromolaena odorata* & S & L & 0.2581 & 0.2581 \\
Sarcocephalus latifolius & S & B, F, L, R & 0.3226 \\
Aframomum alboviolaceum & S & L, R, ST & 0.2419 & 0.4032 \\
Dysphania abrosioides* & D & L, R, W & 0.2419 & 0.3226 \\
Maprounea africana & S & B, L, R & 0.2419 & 0.3226 \\
Monodora myristica & F & B, F, R, S & 0.2419 \\
Xylopia aethiopica & F & F, R, S & 0.2419 \\
\hline
\end{tabular}

(76\%). This value coincides with those of former studies in this area $[7,9]$. The relatively low $\mathrm{F}_{\mathrm{IC}}$ values could be explained by the heterogeneity of vegetation forms in the studied area. In case of non-availability of one plant species, another will be chosen to treat the same disease. Cheikhyoussef et al. [59] reported much higher $\mathrm{F}_{\mathrm{IC}}$ due to the considerably lower number of citations, described species and disease categories [59]. The $\mathrm{F}_{\mathrm{IC}}$ encouraged us to choose reliable data of plants which could be analysed either in medical or phytochemical studies. The majority of the medical applications mentioned at least five times (Table 4) is already known and documented $[11,57,58]$, but a few citations are new to science $(18 \%)$, e.g. Gardenia ternifolia subsp. jovis-tonantis (Welw.) Verdc. seems to be promising for treatment of measles; except in Göhre et al. [7], the use of Brillantaisia owariensis P.Beauv. for cardiovascular diseases was still not documented and Annona stenophylla subsp. cuneata was neither ethnobotanically nor phytochemically investigated although several studies document the use of related species [7]. With decreasing number of citations the quantity of still unknown uses increases. The disease skeletal deformation/scoliosis is rarely mentioned in ethnobotanical literature as its management is dominated by physiotherapies and bracing and not by herbal preparations. Hulse mentioned deer antlers to cure skeleton deformities according to Chinese medicine and called it of dubious credibility [98]. A study from Namibia mentioned Ximenia americana L. as a cure for scoliosis [59]. The standard reference Neuwinger [57] neither mentions skeletal deformation nor scoliosis as traditionally treated diseases [57]. Nevertheless, we documented this traditional healing concept as part of Bakongo health treatment culture.

Administration methods vary from community to community, from healer to healer and from disease to disease. Using a decoction to prepare a remedy is the most frequently found method of preparation (45\%), followed by the manufacture of an ointment (13\%), maceration (12\%) and the application as raw material, while nearly half of all preparations are administered orally (45\%), followed by dermal application (20\%) in only $16 \%$ is an enema used. This is in contrast to commonly used methods used in West African traditional health systems [99]. According to these analyses of administrations, the four most important combinations of preparation and application of medicinal plants are (1) decoction taken orally (21\%); (2) raw material crushed, taken orally, chewed or swallowed (14\%); (3) maceration of plant parts taken orally (11\%); and (4) the preparation of ointment applied to the skin (11\%). These findings are in line with those of several studies $[6,7,100]$.

\section{Nutritional plants}

Thirty percent of mentioned plant species do have a certain nutritional value for local people. Out of the 107 species used for nutrition, 10 were cited more than five times. Besides the species already listed above (Aframomum alboviolaceum (F), Annona stenophylla subsp. cuneata (F), Vitex madiensis (F)), these are as follows: Anisophyllea quangensis Engl. ex Henriq. (F), Dialium englerianum Henriq. (F), Mondia whitei (Hook.f.) Skeels (L), Parinari capensis Harv. (F), Pteridium aquilinum subsp. africanum (L.) Kuhn (L), Strychnos cocculoides Baker (F) and Syzygium guineense (Willd.) DC. (F).

The use of these species is comparable to Biloso and Lejoly [101], who found very similar results in the province Kinshasa, Democratic Republic of Congo. Termote and Van Damme [102] as well as Latham and Konda ku Mbuta [11] also point out the economic importance of these species. On the other hand, $12 \%$ of the citations (13 species) are plants which up to now are not known 
Table 4 Diseases with at least one species mentioned with 5 citations listed in order of its Informant Consensus Factor ( $\left.F_{I C}\right)$. In square brackets the number of citations of disease category (UR) and the $F_{1}$; Known to literature: + known, - not known, *indirectly related; Literature used: Neuwinger, Iwu, Latham and Konda ku Mbuta [11, 57, 58]

\begin{tabular}{|c|c|c|c|}
\hline Disease & Species & UR & $\mathrm{L}$ \\
\hline measles [UR 10; FIC 0.78] & Gardenia ternifolia subsp. jovis-tonantis & 8 & - \\
\hline \multirow{8}{*}{$\begin{array}{l}\text { (bloody) diarrhoea, dysentery } \\
\left.\text { [UR 115; } F_{\mathrm{IC}} 0.61\right]\end{array}$} & Bridelia ferruginea & 11 & + \\
\hline & Hymenocardia acida & 10 & + \\
\hline & Psidium guajava & 8 & + \\
\hline & Combretum racemosum & 6 & + \\
\hline & Diplorhynchus condylocarpon & 6 & + \\
\hline & Elaeis guineensis & 5 & + \\
\hline & Lannea edulis & 5 & + \\
\hline & Syzygium guineense & 5 & + \\
\hline \multirow{5}{*}{$\begin{array}{l}\text { skeletal deformation, scoliosis } \\
\left.\text { [UR 82; } F_{\mathrm{IC}} 0.6\right]\end{array}$} & Aframomum alboviolaceum & 8 & - \\
\hline & Dialium englerianum & 7 & - \\
\hline & Hymenocardia acida & 5 & - \\
\hline & Oncoba welwitschii & 5 & - \\
\hline & Securidaca longipedunculata & 5 & - \\
\hline \multirow[t]{2}{*}{ anaemia [UR 39; $\left.F_{I C} 0.58\right]$} & Annona stenophylla subsp. cuneata & 6 & - \\
\hline & Ochna afzelii subsp. mechowiana & 5 & + \\
\hline \multirow[t]{7}{*}{ stomachache [UR 183; $\left.F_{I C} 0.58\right]$} & Senna occidentalis & 16 & + \\
\hline & Morinda morindoides & 11 & + \\
\hline & Morinda lucida & 10 & + \\
\hline & Sarcocephalus latifolius & 10 & + \\
\hline & Annona stenophylla subsp. cuneata & 6 & + \\
\hline & Rauvolfia vomitoria & 6 & + \\
\hline & Diplorhynchus condylocarpon & 5 & + \\
\hline \multirow[t]{2}{*}{ erectile dysfunction, impotence [UR 59; $\left.F_{I C} 0.57\right]$} & Mondia whitei & 13 & + \\
\hline & Thonningia sanguinea & 9 & * \\
\hline injury, sprain [UR 40; $\left.F_{I C} 0.56\right]$ & Chromolaena odorata & 7 & + \\
\hline hepatitis [UR 16; $\left.F_{I C} 0.53\right]$ & Erythrina abyssinica & 5 & + \\
\hline \multirow[t]{2}{*}{ skin infection, problems, leprosy, cicatrices [UR 79; $\left.F_{I C} 0.5\right]$} & Psorospermum febrifugum & 11 & + \\
\hline & Chaetocarpus africanus & 5 & + \\
\hline \multirow[t]{2}{*}{ parasitic worms (intestine) [UR 59; $\left.F_{\mathrm{IC}} 0.48\right]$} & Morinda morindoides & 8 & + \\
\hline & Morinda lucida & 6 & + \\
\hline \multirow[t]{2}{*}{ fever, malaria [UR 53; $\left.F_{\mathrm{IC}} 0.48\right]$} & Chromolaena odorata & 8 & * \\
\hline & Dysphania ambrosioides & 7 & + \\
\hline toothache, caries [UR 44; $F_{\mathrm{IC}} 0.47$ ] & Maprounea africana & 7 & + \\
\hline heart problems, blood pressure [UR $\left.18 ; F_{I C} 0.47\right]$ & Brillantaisia owariensis & 5 & - \\
\hline respiratory diseases [UR 140; $\left.F_{I C} 0.47\right]$ & Dysphania ambrosioides & 6 & + \\
\hline \multirow[t]{3}{*}{ rheumatism, gout, pain [UR 124; $\left.F_{1 C} 0.47\right]$} & Croton mubango & 11 & + \\
\hline & Securidaca longipedunculata & 9 & + \\
\hline & Vitex madiensis & 6 & + \\
\hline \multirow[t]{2}{*}{ headache, vertigo, weakness, fatigue [UR 101; $F_{I C}$ 0.45] } & Oncoba welwitschii & 5 & + \\
\hline & Vitex madiensis & 5 & + \\
\hline eye parasites, eye problems [UR 36; $\left.F_{I C} 0.4\right]$ & Albizia adianthifolia & 5 & + \\
\hline
\end{tabular}


Table 4 Diseases with at least one species mentioned with 5 citations listed in order of its Informant Consensus Factor ( $\left.F_{I C}\right)$. In square brackets the number of citations of disease category (UR) and the $F_{1}$; Known to literature: + known, - not known, *indirectly related; Literature used: Neuwinger, Iwu, Latham and Konda ku Mbuta $[11,57,58]$ (Continued)

\begin{tabular}{llr}
\hline Disease & Species & UR \\
\hline epilepsy, convulsion [UR 42; $F_{1 C}$ 0.39] & Costus afer & 5 \\
constipation, flatulence [UR 48; $F_{1 C}$ 0.34] & Maprounea africana & + \\
\hline
\end{tabular}

to literature [7, 9, 11, 103-105]. Especially one species should be highlighted: Dracaena camerooniana, whose leaves are locally known as nsalabayakala, is also sold at local markets and therefore of economic value. By contrast, fruits like those of Cnestis ferruginea or Renealmia africana might be edible but not of good taste, so that just a few people do consume these wild fruits, found in the forests. Furthermore, for the consumed aerial parts of Hilleria latifolia toxicity studies showed histopathological changes at high doses [106]. As several species are just cited once, further studies on reliability of data as well as on distribution of species, and their nutritive values and toxicities are recommended.

\section{Influence of gender, age and distance Gender}

It is postulated that women and men have separate and unique relationships with biodiversity [37]. Different studies detected either a gender-specific plant use [59, 107] or gender-independent knowledge [108]. In our study, two thirds of informants were male, one third female. In average, female informants concentrate on using plants from savannahs (49\%) and villages (38\%) while male interviewees focus on the use of forest (40\%) and savannah (44\%) species.

Although women represent just a fifth of all citations (22\%), their contribution to medicinal plants was proportionally even higher $(83 \%)$ than those of men $(74 \%)$ (chi-square test, $\left.P=9 \times 10^{-6}, X^{2}=19.7\right)$. Deleting use categories "medicinal plants" and "nutritional plants", the remaining use categories can be broken down in detail. It appears that all use categories are nearly homogenously distributed regarding their number of citations between genders and do not differ significantly from each other (chi-square test, $P>0.05$ ).

Fifty percent of all plants mentioned in the study were listed just by men, $12 \%$ just by women. When looking at more details of the use category "medicinal plants", a similar pattern can be seen: $48 \%$ of the plants were brought up by men only and $14 \%$ just by women. The ten most important species mentioned for medical application by women and men, with a percentage of more than 50\%, respectively, and the highest numbers of use-reports are shown in Table 5. There is thus a strong suspicion that these species might have a medical application for illnesses specific to women as in Cheikhyoussef et al. [59] or mentioned by Kamatenesi-Mugisha [109]. By contrast, our analyses do not confirm this assumption. Medical plant applications especially for women's illnesses (menstruation problems, birth, pregnancy, open cervix, lactation, and abortive use) are not significantly more frequently quoted by women than others (chi-square test, $P>0.05)$. On the other hand, mens' specific illnesses (erectile dysfunction, impotence) and the associated plants are not mentioned just by men, but by women too. On the contrary, percentages are almost evenly distributed.

In Bakongo culture, both sexes play a plurality of roles. Nevertheless, a majority of men hunts while women maintain the household, take care of the children and work in the field. However, individual differences from person to person blur these culturally not strictly fixed

Table 5 List of 10 species representing $\geq 50 \%$ citations of women and men, respectively (\%) and highest number of use-reports (UR), with their habitat $(H)$, Habitat: $S=$ savanna, $F=$ forest, $V=$ village; *neophyte

\begin{tabular}{|c|c|c|c|c|c|c|c|}
\hline Species mentioned mainly by women & UR & $\%$ & $\mathrm{H}$ & Species mentioned mainly by men & UR & $\%$ & $\mathrm{H}$ \\
\hline Aframomum alboviolaceum & 15 & 54 & $S$ & Annona stenophylla subsp. cuneata & 32 & 91 & $\mathrm{~S}$ \\
\hline Dialium englerianum & 8 & 50 & S & Hymenocardia acida & 28 & 70 & $\mathrm{~S}$ \\
\hline Jatropha curcas* & 7 & 64 & V & Securidaca longipedunculata & 26 & 90 & $S$ \\
\hline Combretum psidioides & 6 & 86 & S & Sarcocephalus latifolius & 25 & 78 & $S$ \\
\hline Ekebergia benguelensis & 6 & 67 & $\mathrm{~S}$ & Monodora myristica & 24 & 80 & $\mathrm{~F}$ \\
\hline Stachytarpheta cayennensis* & 6 & 67 & V & Vitex madiensis & 23 & 66 & $S$ \\
\hline Gaertnera paniculata & 5 & 100 & $\mathrm{~F}$ & Chromolaena odorata* & 22 & 88 & $\mathrm{~S}$ \\
\hline Cola acuminata & 5 & 63 & $\mathrm{~F}$ & Psorospermum febrifugum & 22 & 85 & $S$ \\
\hline Zingiber officinale* & 4 & 100 & V & Bridelia ferruginea & 21 & 84 & $S$ \\
\hline Strychnos pungens & 4 & 80 & S & Morinda lucida & 21 & 91 & $S, F$ \\
\hline
\end{tabular}


boundaries, so that men also help on the fields. The results of our study on the influence of gender on plant usage in all areas of daily life did not show prominent differences of genders in traditional plant usage of Bakongo tribes. Handicraft and house constructing activities are performed by both sexes, depending on the transfer of knowledge within the families rather than on gender. Not even in the context of gender-specific illnesses, significant differences could be detected. That all adds up to the conclusion that treatment of illnesses is open and pragmatic and not biased by gender. This notion also contradicts the self-perception of male healers who "use plants of whose women do not know their effects". But further studies should be undertaken to support this observation, also because the percentage of women was low.

\section{Distance to Uíge city}

As the study was conducted in the whole province covering an area of $59,000 \mathrm{~km}^{2}$, different vegetation zones are included which merge together seamlessly forming a complex mosaic. For this reason, it is difficult to detect a clear influence of the distance in regard to species composition in traditional healer's concepts. What could be detected significantly with respect to the distance to Uíge city are differences in two use categories. The larger the distance, the higher the number of use citations of medical plants ranging from $72 \%$ (zone A) to $80 \%$ (zone B) (chi-square test, $P=9 \times 10^{-6}, X^{2}=19.6$ ) while the use of nutritional plants decrease from $12 \%$ (zone A) to $8 \%$ (zone B) (chi-square test, $P=0.002, x^{2}=9.6$ ). Neither plant part utilization nor medical plant explanation or age of informants was significantly different. With increasing distance from the city Uíge and its manifold offers of modern society such as health centres or supermarkets, no significant difference of plant usage could be detected (chi-square test, $P>0.05$ ). Similar results were achieved by Ávila et al. [64] who, depending on different urbanization levels, documented the maintenance of a similar ethnobotanical repertoire in Brazilian Quilombola groups. In contrast, Pirker et al. [110] stated an influence of rural-urban urbanization and globalization processes on traditional knowledge. This should be more fully investigated, especially in accordance with the shifts from traditional healing to modern health care in Angola.

\section{Age}

Nearly one third of informants were younger than 40 years whereas only a quarter of all citations were mentioned by this group. The older people therefore show a significantly greater knowledge (chi-square test, $P=0.000955, X^{2}=10.913$ ). Especially concerning the use category "medicine", significantly more uses were mentioned by the older people (chi-square test, $P=$ 0.00097, $X^{2}=10.877$ ). Voeks [107] described a similar situation in northeast Brazil and justified his results to show that the greater knowledge of plant medicinal properties was linked to the greater age of the participant. The reason that the number of young healers is comparatively low is explained by the slow process of transferring knowledge from one generation to another [59]. Further studies should compare firstly younger people and secondly people from urban and rural areas, regardless of their knowledge.

\section{Conclusion}

Despite (or because of) the long-lasting military conflict in Angola, traditional knowledge of plant usage is still an important part of cultural heritage. Plants therefore are essential elements in all areas of livelihood, especially in the medical sector. This situation is compounded by the still very poor health care system in the country, especially in rural areas.

The study reveals the following key messages:

1. A considerable heterogeneity in plant usage of the studied area could be detected, influenced by the high complexity of flora composed of both, GuineoCongolian and Zambesian elements and the diverse topography.

2. Although the area is large, no significant influence of the distance in regard to species composition in traditional healer's concepts of the respective village was found.

3. Although several plants were just mentioned by women or men, respectively, no significant restriction to gender-specific illnesses in medical plant use could be found.

4. Merely concerning the age of informants a slight shift could be detected, because one third of informants were younger than 40 years whereas only one fourth of all citations were mentioned by this group. Regarding the analysis within use categories, this tendency could not be substantiated significantly.

5. At least three species are worth evaluating for their pharmacological potential due to their high $\mathrm{F}_{\mathrm{IC}}$ value regarding the following diseases: Gardenia ternifolia subsp. jovis-tonantis seems to be promising for treatment of measles; Brillantaisia owariensis has still not been analysed for treating cardiovascular diseases; Annona stenophylla subsp. cuneata was mentioned for treating anaemia.

People in Angola still depend very much on the natural environment, and the knowledge of how to use plants in their daily life is fundamental-even people living in the 
large cities or urban areas do have family in the rural regions or at least have lived part of their life there. But by virtue of the already existing and for the future expected urbanization and the resultant loss of direct dependence upon nature, traditional knowledge is expected to be lost in future [111], especially if taking into account that Angola has a high amount of unused land, suitable for crops which will be converted in near future, resulting in a negative impact on biodiversity [112]. The study therefore at the same time provides an important contribution of traditional knowledge documentation, which so far is very rare for the area investigated here. Collected data are a worthwhile base for the establishment of a Botanical Garden integrated in the Universidade Kimpa Vita in Uíge with focus on useful plants. Furthermore, ethnopharmacological studies of several selected plant species might usefully be undertaken.

\section{Additional file}

Additional file 1: Short movie: Two of the authors during field studies in Uíge. A traditional healer demonstrates the preparation and application of an herbal funnel. (MOV $142656 \mathrm{~kb}$ )

\section{Abbreviations}

Cl: Cultural Importance Index; COI: Herbarium Coimbra; FIC : Informant Consensus Factor; LISC : Herbarium Lisbon; RFC: Relative Frequency of Citations

\section{Acknowledgements}

The analysis and discussion contained within this article would not have been possible without the contribution of knowledge from the villagers of the province of Uíge. The University Kimpa Vita was an essential base for operations and provided logistical support. The authors would like to thank Barbara Ditsch, Gerard van der Weerden, Paul Latham, Christian Schulz, Daniel Nickrent, Anne Göhre, Roseli Buzanelli Torres, Thomas Couvreur and Ulrich Meve for assistance in the identification of selected herbarium specimens. We are also grateful to the Herbarium LISC in Lisbon and the Herbarium COI in Coimbra, Portugal for the assistance as well as to the Botanical Garden of the TU Dresden for cultivating plants until essential characters for identification appeared. Thanks to Andreas Kempe for preparing Fig. 1 and Stefan Bischoff for preparing Fig. 2.

We acknowledge support by the Open Access Publication Funds of the SLUB/TU Dresden.
\end{abstract}

\section{Funding}

The fieldwork in Angola was supported by a travel fund from the German Academic Exchange Service (DAAD) and the program "Strategic Partnerships" of the TU Dresden. These published results were obtained in collaboration with the Instituto Nacional da Biodiversidade e Áreas de Conservação (INBAC) of the Ministério do Ambiente da República de Angola.

\section{Availability of data and materials}

All data are available from the corresponding author. All voucher specimens are deposited in the Herbarium Dresdense (DD) of the Institute of Botany, Technische Universität Dresden, Germany. As soon as suitable conditions are established, parts of the collection will be deposited at University Kimpa Vita, Uíge, Angola.

\section{Authors' contributions}

TL carried out field work, analysed the collected data and drafted the manuscript. MM, MP, JLM and MFB participated in field work and established contact with local people. $\mathrm{CH}$ and $\mathrm{CN}$ participated in the design of the study and helped to draft the manuscript. All authors read and approved the final manuscript.

\section{Authors' information}

Since 2012, the Universidade Kimpa Vita in Uíge, Angola and the Technische Universität Dresden, Germany, have a multifaceted cooperation including the establishment of a Botanical Garden with the focus on local medicinal plants as well as biodiversity assessments.

Ethics approval and consent to participate

Not applicable.

\section{Consent for publication}

Not applicable.

\section{Competing interests}

The authors declare that they have no competing interests.

\section{Publisher's Note}

Springer Nature remains neutral with regard to jurisdictional claims in published maps and institutional affiliations.

\section{Author details}

'Department of Biology, Institute of Botany, Faculty of Science, Technische Universität Dresden, 01062 Dresden, Germany. ${ }^{2}$ University Kimpa Vita, Province of Uíge, Rua Henrique Freitas No. 1, Bairro Popular, Uíge, Angola.

Received: 10 February 2018 Accepted: 29 May 2018

Published online: 25 July 2018

\section{References}

1. Figueiredo E, Smith G. Plants of Angola = Plantas de Angola. South African National Biodiversity Institute (SANBI); 2008.

2. Caldecott JO, Jenkins MD, Johnson TH, Groombridge B. Priorities for conserving global species richness and endemism. Biodivers Conserv. 1996;5:699-727.

3. Bossard E. La medecine traditionnelle au centre et a l'ouest de l'Angola. Lisboa: Ministério da Ciência e da Tecnologia, Instituto de Investigação Científica Tropical; 1987.

4. Bossard E. Angolan medicinal plants used also as piscicides and/or soaps. J Ethnopharmacol. 1993:40:1-19.

5. Bruschi P, Urso V, Solazzo D, Tonini M, Signorini MA. Traditional knowledge on ethno-veterinary and fodder plants in South Angola: an ethnobotanic field survey in Mopane woodlands in Bibala, Namibe province. J Agric Environ Int Dev. 2017; Available from: http://www.jaeid.it/ojs/index.php/ JAEID/article/view/559. [cited 24 Apr 2018]

6. Urso V, Signorini MA, Tonini M, Bruschi P. Wild medicinal and food plants used by communities living in mopane woodlands of southern Angola: results of an ethnobotanical field investigation. J Ethnopharmacol. 2016;177:126-39.

7. Göhre A, Toto-Nienguesse ÁB, Futuro M, Neinhuis C, Lautenschläger T. Plants from disturbed savannah vegetation and their usage by Bakongo tribes in Uíge, Northern Angola. J Ethnobiol Ethnomed. 2016;12. Available from: http:// www.ncbi.nlm.nih.gov/pmc/articles/PMC5030725/. [cited 3 Mar 2017]

8. Mawunu M, Bongo K, Eduardo A, Vua MMZ, Ndiku L, Mpiana PT, et al. Contribution à la connaissance des produits forestiers non ligneux de la Municipalité d'Ambuila (Uíge, Angola): Les plantes sauvages comestibles [Contribution to the knowledge of no-timber forest products of Ambuila Municipality (Uíge, Angola): The wild edible plants]. Int J Innov Sci Res. 2016;26

9. Heinze C, Ditsch B, Congo MF, Lautenschläger T, Neinhuis C. First ethnobotanical analysis of useful plants in Cuanza Norte, North Angola. Res Rev J Bot Sci. 2017;6:44-53.

10. Senwitz C, Kempe A, Neinhuis C, Mandombe JL, Branquima MF, Lautenschläge T. Almost forgotten resources - biomechanical properties of traditionally used Bast fibers from northern Angola. Bioresources. 2016;11:7595-607.

11. Latham P, Konda ku Mbuta A. Useful plants of Bas-Congo province, Democratic Republic of Congo. 2014

12. Lorenz K, Mündl K. "Rettet die Hoffnung": Konrad Lorenz im Gespräch mit Kurt Mündl. 2. Aufl. Wien u.a: Jugend- u. Volk-Verl.-Ges; 1989.

13. Gandolfo ES, Hanazaki N. Etnobotânica e urbanização: conhecimento e utilização de plantas de restinga pela comunidade nativa do distrito do Campeche (Florianópolis, SC). Acta Bot Bras. 2011;25:168-77. 
14. Ramirez CR. Ethnobotany and the loss of traditional knowledge in the 21st century. Ethnobot Res Appl. 2007;5:245-7.

15. WHO. Health status and trends [Internet]. 2015. Available from: http://www. aho.afro.who.int/sites/default/files/publications/5101/Atlas2016-en_Healthstatus-and-trends.pdf. [cited 29 May 2017]

16. WHO | World Health Statistics 2016: Monitoring health for the SDGs [Internet]. WHO. 2016. Available from: http://www.who.int/gho/publications/ world_health_statistics/2016/en/. [cited 29 May 2017]

17. Sousa-Figueiredo JC, Gamboa D, Pedro JM, Fançony C, Langa AJ, Soares Magalhães RJ, et al. Epidemiology of malaria, schistosomiasis, geohelminths, anemia and malnutrition in the context of a demographic surveillance system in Northern Angola. Noor AM, editor. PLoS One 2012;7:e33189.

18. Smith LC, Ruel MT, Ndiaye A. Why is child malnutrition lower in urban than in rural areas? Evidence from 36 developing countries. World Dev. 2005;33: 1285-305.

19. Moyo M, Aremu AO, Van Staden J. Medicinal plants: an invaluable, dwindling resource in sub-Saharan Africa. J Ethnopharmacol. 2015;174:595-606.

20. Peel MC, Finlayson BL, McMahon TA. Updated world map of the KöppenGeiger climate classification. Hydrol Earth Syst Sci. 2007;11:1633-44.

21. Briggs DJ, Smithson P. Fundamentals of physical geography: Rowman \& Littlefield; 1986.

22. Romeiras MM, Figueira R, Duarte MC, Beja P, Darbyshire I. Documenting biogeographical patterns of African timber species using herbarium records: a conservation perspective based on native trees from Angola. Vendramin GG, editor PLoS ONE 2014;9:e103403.

23. Marquardsen H, Stahl A. Angola. Berlin: Dietrich Reimer; 1928.

24. White $F$. The vegetation of Africa / a descriptive memoir to accompany the Unesco/AETFAT/UNSO vegetation map of Africa [Internet]. Paris: Unesco; 1983. Available from: http://primoproxy.slub-dresden.de/cgi-bin/permalink. pl?libero mab213695056

25. Olson DM, Dinerstein E, Wikramanayake ED, Burgess ND, Powell GVN, Underwood EC, et al. Terrestrial ecoregions of the world: a new map of life on earth. Bioscience. 2001;51:933.

26. Barbosa LAG. Carta fitogeográfica de Angola: Instituto de Investigação Científica de Angola; 1970.

27. Biodiversity MNJA. War, and tropical forests. J Sustain For. 2008;16:1-20.

28. Hansen MC, Potapov PV, Moore R, Hancher M, Turubanova SA, Tyukavina A, et al. High-resolution global maps of 21st-century Forest cover change. Science. 2013;342:850-3.

29. FAO. EVALUATION DES RESSOURCES FORESTIËRES MONDIALES 2010 RAPPORT NATIONAL ANGOLA [Internet]. Rom; 2010. Available from: http:// www.fao.org/docrep/013/al442F/al442f.pdf

30. Horsten F, Natureza DN da C da, Por L (Angola). Madeira: una analise da situacao actual. 1983; Available from: http://agris.fao.org/agris-search/search. do?recordID=XF2015031279. [cited 26 May 2017]

31. Pauwels L. Nzayilu N'ti, guide des arbres et arbustes de la région de Kinshasa-Brazzaville: Jardin botanique national de Belgique; 1993.

32. Lautenschläger $T$, Neinhuis $C$, editors. Riquezas naturais de Uíge: uma breve introdução sobre o estado atual, a utilização, a ameaça e a preservação da biodiversidade. Dresden: Techn. Univ; 2014.

33. Censo. Censo 2014 [Internet]. 2014. Available from: http://censo.ine.gov.ao/ xportal/xmain?xpid=censo2014\&xpgid=provincias\&provincias-generic-detail_ qry $=$ BOUI $=10504841$ \&actualmenu=10504841\&actualmenu=8377485. [cited 3 Mar 2017]

34. Kagawa RC, Anglemyer A, Montagu D. The scale of faith based organization participation in health service delivery in developing countries: systemic review and meta-analysis. Beck EJ, editor PLoS ONE 2012;7:e48457.

35. Kristof N. Deadliest Country for Kids. N Y Times [Internet]. 2015 Mar 19, Available from: https://www.nytimes.com/2015/03/19/opinion/nicholaskristof-deadliest-country-for-kids.html. [cited 26 May 2017]

36. Queza AJ. Sistema Nacional de Sade Angolano e Contributos Luz da Reforma do SNS Portugus.pdf [Internet]. 2010. Available from: https:// repositorio-aberto.up.pt/bitstream/10216/50407/2/Sistema\%20Nacional\% 20de $\% 20$ Sade $\% 20$ Angolano\%20e\%20Contributos\%20\%20Luz $\% 20$ da\%20Reforma\%20do\%20SNS\%20Portugus.pdf. [cited 26 May 2017]

37. Pfeiffer JM, Butz RJ. Assessing cultural and ecological variation in ethnobiological research: the importance of gender. J Ethnobiol. 2005;25:240-78.

38. Cunningham AB. Applied ethnobotany: people, wild plant use, and conservation. London: Earthscan; 2001.
39. Silva HCH, Caraciolo RLF, Marangon LC, Ramos MA, Santos LL, Albuquerque UP. Evaluating different methods used in ethnobotanical and ecological studies to record plant biodiversity. J Ethnobiol Ethnomedicine. 2014;10:48.

40. Carrisso LW. Conspectus florae angolensis. 1937.

41. Akoègninou $A$, van der Burg WJ, van der Maesen LJ. Flore analytique du Bénin: Backhuys; 2006

42. Hutchinson J, Dalziel JM, Hepper F. Flora of West Tropical Africa: The British West African territories, Liberia, the French and Portuguese territories South of latitude $18^{\circ} \mathrm{N}$. to Lake Chad, and Fernando Po. 2. London: Crown agents for Oversea Governments and Administrations; 1954.

43. Hutchinson J, Dalziel JM, Hepper F. Flora of West Tropical Africa: The British West African territories, Liberia, the French and Portuguese territories South of latitude $18^{\circ} \mathrm{N}$. to Lake Chad, and Fernando Po. 2. London: Crown agents for Oversea Governments and Administrations; 1958.

44. Hutchinson J, Dalziel JM, Hepper F. Flora of West Tropical Africa: All territories in West Africa South of latitude $18^{\circ} \mathrm{N}$. and to the West of Lake Chad, and Fernando Po. 2nd ed. London: Crown agents for Oversea Governments and Administrations; 1963.

45. Hutchinson J, Dalziel JM, Hepper F. Flora of West Tropical Africa: All territories in West Africa South of latitude $18^{\circ} \mathrm{N}$. and to the West of Lake Chad, and Fernando Po. 2. London: Crown agents for Oversea Governments and Administrations; 1968.

46. Hutchinson J, Dalziel JM, Hepper F. Flora of West Tropical Africa: All territories in West Africa South of latitude $18^{\circ} \mathrm{N}$. and to the West of Lake Chad, and Fernando Po. 2. London: Crown agents for Oversea Governments and Administrations; 1972

47. Royal Botanic Gardens Kew. Flora Zambesica [Internet]. 2007. Available from: http://apps.kew.org/efloras/search.do;sessionid= 112B8733022D60552751FB72E19ECOA6. [cited 29 May 2017]

48. Royal Botanic Gardens Kew. Kew Herbarium Catalogue [Internet]. 2014. Available from: http://apps.kew.org/herbcat/navigator.do. [cited 29 May 2017]

49. Naturalis Biodiversity Center [Internet].. Available from: http://www.naturalis. nl/en/. [cited 29 May 2017]

50. Instituto de Investigação Científica Tropical Portugal. Herbário LISC [Internet]. 2007. Available from: http://maerua.iict.pt/colecoes/herb_ simplesearch.php. [cited 29 May 2017]

51. Tardío J, Pardo-de-Santayana M. Cultural importance indices: a comparative analysis based on the useful wild plants of Southern Cantabria (Northern Spain)1. Econ Bot. 2008;62:24-39.

52. Kufer J, Heinrich M, Förther $\mathrm{H}$, Pöll E. Historical and modern medicinal plant uses - the example of the Ch'orti ' Maya and Ladinos in eastern Guatemala. J Pharm Pharmacol. 2005;57:1127-52.

53. McDonald J. Handbook of biological statistics: Sparky House Publishing; 2015.

54. Ahmad M, Sultana S, Fazl-I-Hadi S, Ben Hadda T, Rashid S, Zafar M, et al. An ethnobotanical study of medicinal plants in high mountainous region of Chail valley (District Swat- Pakistan). J Ethnobiol Ethnomed. 2014;10:36.

55. Heinrich M, Ankli A, Frei B, Weimann C, Sticher O. Medicinal plants in Mexico: healers' consensus and cultural importance. Soc Sci Med. 1998:47:1859-71.

56. Trotter RT, Logan M. Informant consensus: a new approach for identifying potentially active medicinal plants. In: Plants in indigenous medicine and diet: Biobehavioural approaches; 1986. p. 91-112.

57. Neuwinger HD. African traditional medicine: a dictionary of plant use and applications with supplement : search system for diseases. Stuttgart: Medpharm Scientific Publishers; 2000.

58. Iwu M. Handbook of African medicinal plants. 2nd ed. Boca Raton: CRC Press; 2014

59. Cheikhyoussef A, Shapi M, Matengu K, Ashekele HM. Journal of ethnobiology and Ethnomedicine. J Ethnobiol Ethnomed. 2011;7:10.

60. Luoga EJ, Witkowski ETF, Balkwill K. Differential utilization and ethnobotany of trees in kitulanghalo forest reserve and surrounding communal lands, eastern Tanzania. Econ Bot. 2000;54:328-43.

61. Schnitzer SA, Bongers F. The ecology of lianas and their role in forests. Trends Ecol Evol. 2002;17:223-30.

62. Dewalt SJ, Schnitzer SA, Denslow JS. Density and Diversity of Lianas along a Chronosequence in a central Panamanian lowland Forest. J Trop Ecol. 2000; 16:1-19.

63. Sitte P, Weiler EW, Kadereit JW, Bresinsky A, Körner C. Strasburger Lehrbuch der Botanik. Mit CD-ROM. Heidelberg: Spektrum Akademischer Verlag; 2002.

64. Avila JV da C, Zank S, Valadares KM de O, Maragno JM, Hanazaki N. The traditional knowledge of Quilombola about plants: does urbanization matter? Ethnobot Res Appl. 2015;14:453-62. 
65. Bennett BC, Prance GT. Introduced plants in the indigenous pharmacopoeia of northern South America. Econ Bot. 2000;54:90-102.

66. Dos Santos LL, do Nascimento ALB, Vieira FJ, da Silva VA, Voeks R, Albuquerque UP. The cultural value of invasive species: a case study from semi-arid northeastern Brazil. Econ Bot. 2014;68:283-300.

67. Alencar NL, Santoro FR, Albuquerque UP. What is the role of exotic medicinal plants in local medical systems? A study from the perspective of utilitarian redundancy. Rev Bras Farmacogn. 2014;24:506-15.

68. Medeiros PM, Júnior WSF, Ramos MA, da Silva TC, Ladio AH, Albuquerque UP. Why do people use exotic plants in their local medical systems? A systematic review based on Brazilian local communities. PLoS One. 2017;12:e0185358.

69. Yadav JP, Arya V, Yadav S, Panghal M, Kumar S, Dhankhar S. Cassia occidentalis $L .:$ a review on its ethnobotany, phytochemical and pharmacological profile. Fitoterapia. 2010;81:223-30.

70. Voeks R. African medicine and magic in the Americas. Geogr Rev. 1993;83:66.

71. GISD [Internet]. Available from: http//www.iucngisd.org/gisd/. [cited 24 May 2017].

72. Boy G, Witt A. INVASIVE ALIEN PLANTS. 2013; Available from: http://citeseerx. ist.psu.edu/viewdoc/download?doi=10.1.1.403.962\&rep=rep1\&type=pdf. [cited 23 May 2017]

73. Akol AM, Chidege MY, Talwana HAL, Mauremootoo JR. Invertebrate pests of maize in East Africa (Kenya, Uganda and Tanzania), Lucid v. 3.5 key and fact sheets [Internet]. Makerere University, TPRI, BioNET-EAFRINET, CABI \& The University of Queensland (September 2011); 2011. Available from: keys. lucidcentral.org/keys/v3/EAFRINET

74. Vodouhê FG, Coulibaly O, Greene C, Sinsin B. Estimating the local value of non-timber forest products to pendjari biosphere reserve dwellers in Benin. Econ Bot. 2009;63:397.

75. Giday M, Teklehaymanot T, Animut A, Mekonnen Y. Medicinal plants of the Shinasha, Agew-awi and Amhara peoples in northwest Ethiopia. J Ethnopharmacol. 2007;110:516-25.

76. Cheikhyoussef A, Embashu W. Ethnobotanical knowledge on indigenous fruits in Ohangwena and Oshikoto regions in northern Namibia. J Ethnobiol Ethnomed. 2013;9:34.

77. Balick MJ, Cox PA. Plants, people, and culture: the science of ethnobotany. New York: W H Freeman \& Co; 1996.

78. Parveen, Upadhyay B, Roy S, Kumar A. Traditional uses of medicinal plants among the rural communities of Churu district in the Thar Desert, India. J Ethnopharmacol. 2007;113:387-99.

79. Panghal M, Arya V, Yadav S, Kumar S, Yadav JP. Indigenous knowledge of medicinal plants used by Saperas community of Khetawas, Jhajjar District, Haryana, India. J Ethnobiol Ethnomed. 2010;6:4

80. Mander M. Marketing of Indigenous Medicinal Plants in South Africa : A case study in Kwazulu-Natal [Internet]. ResearchGate. 1998. Available from: https://www.researchgate.net/publication/267266779_Marketing_of_ Indigenous_Medicinal_Plants_in_South_Africa_A_case_study_in_KwazuluNatal. [cited 29 May 2017]

81. Cunningham AB. African medicinal plants. U N Educ Sci Cult Organ Paris Fr [Internet]. 1993; Available from: http://www.academia.edu/download/ 7985865/wp1e.pdf. [cited 29 May 2017]

82. Gupta R, Reid M. Macroeconomic surprises and stock returns in South Africa. Stud Econ Finance. 2013;30:266-82.

83. Jusu A, Sanchez AC. Medicinal plant trade in Sierra Leone: threats and opportunities for conservation. Econ Bot. 2014;68:16-29.

84. Obi SNC. Fortmann L, Bruce JW, editors. Women's rights and interests in trees. In whose trees? Proprietary dimensions of forestry, vol. 1988: Westview Press Boulder. p. 240-2.

85. Pearce JMS. The doctrine of signatures. Eur Neurol. 2008;60:51-2.

86. Böhme J, Ellistone d. 1652 John. Signatura rerum, or, The signature of all things : shewing the sign and signification of the severall forms and shapes in the creation, and what the beginning, ruin, and cure of every thing is [Internet]. London : Printed by John Macock for Gyles Calvert; 1651. Available from: http://trove.nla.gov.au/work/7123615. [cited 24 May 2017]

87. Sundram K. Palm fruit chemistry and nutrition. Asia Pacific J Clin Nutr. 2003;

88. Poitou F, Masotti V, de SSG, Viano J, Gaydou EM. Composition of the essential oil of Xylopia aethiopica dried fruits from Benin. J Essent Oil Res. 1996;8:329-30.

89. Loubelo E. Impact des produits forestiers non ligneux (PFNL) sur l'économie des ménages et la sécurité alimentaire : cas de la République du Congo [Internet] [phdthesis]. Université Rennes 2; 2012. Available from: https://tel. archives-ouvertes.fr/tel-00713758/document. [cited 24 May 2017]

90. Adjanohoun E, Organization of African Unity, Scientific T and Research Commission. Contribution to ethnobotanical and floristic studies in Uganda.
Place of publication not identified: Organization of African Unity, Scientific Technical \& Research Commission = Organisation de l'unit é africaine, Commission scientifique technique et de la recherche; 1993.

91. Chamratpan S. Biodiversity of medicinal mushrooms in Northeast Thailand. In: Proc 2nd Int Conf med mushroom Int Conf biodivers bioact Compd; 2003.

92. Hartke K, Mutschler E, Rücker G. Deutsches Arzneibuch ( DAB 10). 10. Ausgabe 1991:. Wissenschaftliche Erläuterungen zum Deutschen Arzneibuch. 1991.

93. Jiofack T, Fokunang C, Guedje N, Kemeuze V, Fongnzossie E, Nkongmeneck $\mathrm{BA}$, et al. Ethnobotanical uses of medicinal plants of two ethnoecological regions of Cameroon. Int J Med Med Sci. 2010;2:60-79.

94. Erinoso S. M. Ethnobotanical survey of some medicinal plants used in traditional health care in Abeokuta areas of Ogun State, Nigeria. Afr J Pharm Pharmacol [Internet]. 2012;6. Available from: http://www.academicjournals. org/ajpp/abstracts/abstracts/abstract\%202012/15\%20May/ Erinoso\%20and\%20Aworinde.htm. [cited 23 May 2017]

95. Prusti $A B$, Behera KK. Ethnobotanical exploration of Malkangiri district of Orissa. India Ethnobot Leafl. 2007;2007:14.

96. Kouamé PB-K, Jacques C, Bedi G, Silvestre V, Loquet D, Barillé-Nion S, et al Phytochemicals isolated from leaves of Chromolaena odorata : impact on viability and Clonogenicity of Cancer cell lines: ANTICANCER ACTIVITY OF CHROMOLAENA ODORATA LEAF EXTRACTS. Phytother Res. 2013;27:835-40.

97. Suriyavathana M, Parameswari G, Shiyan SP. Biochemical and antimicrobial study of Boerhavia erecta and Chromolaena odorata (L.) King \& Robinson. Int J Pharm Sci Res. 2012;3:465.

98. Hulse $\mathrm{JH}$. Biotechnologies: past history, present state and future prospects Trends Food Sci Technol. 2004:15:3-18.

99. van Andel T, van Onselen S, Myren B, Towns A, Quiroz D. "The medicine from behind": the frequent use of enemas in western African traditional medicine. J Ethnopharmacol. 2015;174:637-43.

100. Mesfin F, Demissew S, Teklehaymanot T. An ethnobotanical study of medicinal plants in Wonago Woreda, SNNPR, Ethiopia. J Ethnobiol Ethnomed. 2009;5:28.

101. Biloso A, Lejoly J. Etude de l'exploitation et du marché des produits forestiers non ligneux à Kinshasa. Tropicultura. 2006;24:183-8.

102. Termote C, Van Damme P. Wild edible plant use in Tshopo District, DR Congo: Universiteit Gent; 2012.

103. Kibungu Kembelo A, Kibungu Kembelo P. Contribution à l'étude des plantes alimentaires des populations du territoire de Madimba. Jard Bot Kisantu. 2010;

104. Latham P, Konda ku Mbuta A. Some honeybee plants of Bas-Congo province, Democratic Republic of Congo. 2011.

105. PROTA4U. Prota4U.org [Internet]. 2017. Available from: https://www.prota4u. org/database/protav8.asp?h=M26\&t=Cryptolepis_sanguinolenta\&p= Cryptolepis+sanguinolenta\#MajorReferences. [cited 1 Dec 2018]

106. Abotsi WK, Ainooson GK, Gyasi EB, Abotsi WKM. Acute and sub-acute toxicity studies of the ethanolic extract of the aerial parts of Hilleria latifolia (Lam.) $\mathrm{H}$. Walt.(Phytolaccaceae) in rodents. West Afr J Pharma. 2011;22:27-35.

107. Voeks RA. Are women reservoirs of traditional plant knowledge? Gender, ethnobotany and globalization in Northeast Brazil. Singap J Trop Geogr. 2007;28:7-20

108. Bradacs G, Heilmann J, Weckerle CS. Medicinal plant use in Vanuatu: a comparative ethnobotanical study of three islands. J Ethnopharmacol. 2011; 137:434-48.

109. Kamatenesi-Mugisha M, Oryem-Origa H. Traditional herbal remedies used in the management of sexual impotence and erectile dysfunction in western Uganda. Afr Health Sci. 2005:5:40-9.

110. Pirker H, Haselmair R, Kuhn E, Schunko C, Vogl CR. Transformation of traditional knowledge of medicinal plants: the case of Tyroleans (Austria) who migrated to Australia, Brazil and Peru. J Ethnobiol Ethnomedicine. 2012:8:44.

111. Cohen B. Urbanization in developing countries: current trends, future projections, and key challenges for sustainability. Technol Soc. 2006;28:63-80.

112. Jenkins M. Prospects for biodiversity. Science. 2003;302:1175-7. 